\title{
Clientelismo político, ¿desviación de la política o forma de representación? Estado del arte sobre las aproximaciones al clientelismo en Colombia 1973-2011
}

Laura Daniela Guerrero García

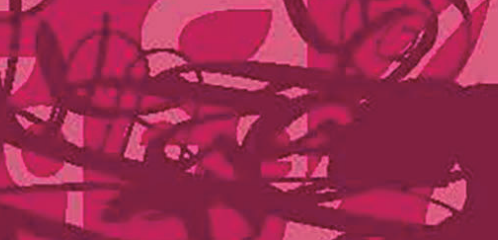

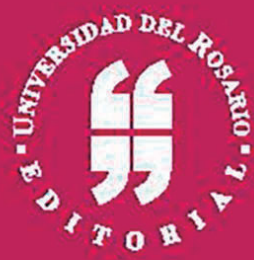

Opera Prima

Facultades de Ciencia Política y Gobierno, y de Relaciones Internacionales 

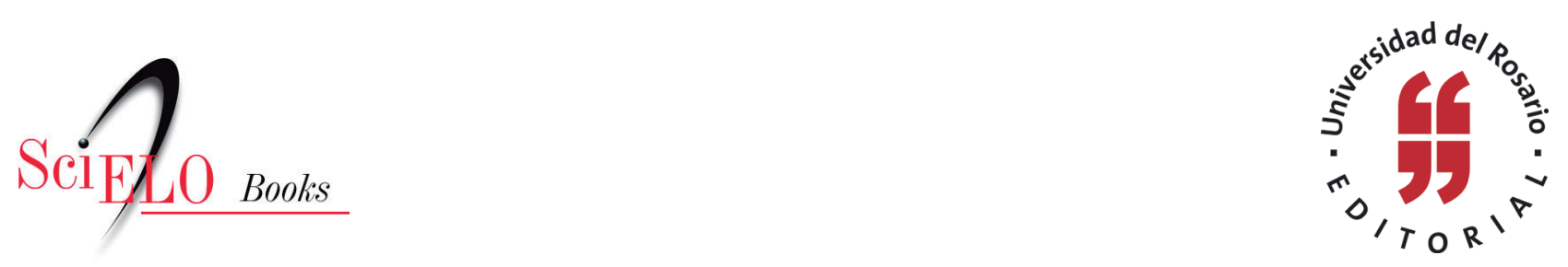

\section{Clientelismo político, ¿desviación de la política o forma de representación?

\author{
Estado del arte sobre las aproximaciones al clientelismo en \\ Colombia 1973-2011
}

Laura Daniela Guerrero García

GUERRERO GARCÍA, L.D. Clientelismo político, ¿desviación de la política o forma de representación?: Estado del arte sobre las aproximaciones al clientelismo en Colombia 1973-2011 [online]. Bogotá: Editorial Universidad del Rosario, 2014, 152 p. Opera prima collection. ISBN: 978-958-738-552-6. https://doi.org/10.7476/9789587385526.

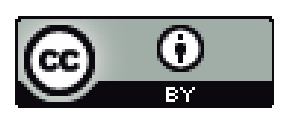

All the contents of this work, except where otherwise noted, is licensed under a Creative Commons Attribution 4.0 International license.

Todo o conteúdo deste trabalho, exceto quando houver ressalva, é publicado sob a licença Creative Commons Atribição 4.0.

Todo el contenido de esta obra, excepto donde se indique lo contrario, está bajo licencia de la licencia Creative Commons Reconocimento 4.0. 


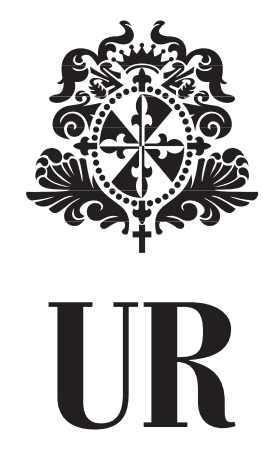





\section{CLIENTELISMO POLÍTICO, ¿DESVIACIÓN DE LA POLÍTICA O FORMA DE REPRESENTACIÓN?}

LAURA DANIELA GUERRERO GARCÍA 



\section{CLIENTELISMO POLÍTICO, ¿DESVIACIÓN DE LA POLÍTICA O FORMA DE REPRESENTACIÓN? Estado del arte sobre las}

aproximaciones al clientelismo en Colombia 1973-2011 


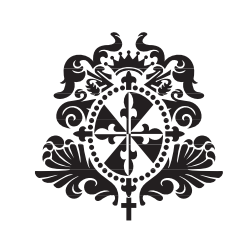

\section{Colección Opera Prima}

(C) 2014 Editorial Universidad del Rosario

(C) 2014 Universidad Colegio Mayor de Nuestra Señora del Rosario, Facultades de Ciencia Política y Gobierno y de Relaciones Internacionales

(C) 2014 Laura Daniela Guerrero García

ISBN: 978-958-738-551-9 (rústica)

ISBN: 978-957-738-552-6 (digital)

Primera edición: Bogotá D.C., diciembre de 2014

Coordinación editorial: Editorial Universidad del Rosario

Corrección de estilo: Manuel Gómez

Montaje de cubierta: Precolombi EU - David Reyes

Diagramación: Martha Echeverry

Impresión: Estrategikmente Ltda.

Editorial Universidad del Rosario

Carrera 7 No 12B-41, oficina 501• Teléfono 2970200

Todos los derechos reservados. Esta obra no puede ser reproducida

sin el permiso previo por escrito de la Editorial Universidad del Rosario

Guerrero García, Laura Daniela

Clientelismo político, ¿desviación de la política o forma de representación?: Estado del arte sobre las aproximaciones al clientelismo en Colombia 1973-2011 / Laura Daniela Guerrero

García. - Bogotá: Editorial Universidad del Rosario, Facultades de Ciencia Política y

Gobierno y de Relaciones Internacionales, 2014.

189 páginas: - (Colección Ópera Prima).

ISBN: 978-958-738-551-9 (rústica)

ISBN: 978-958-738-552-6 (digital)

Ciencia política / Partidos políticos / Corrupción política / Corrupción administrativa / Ética política / I. Título / II. Serie.

SCDD 20

Catalogación en la fuente - Universidad del Rosario. Biblioteca

$\mathrm{amv}$

Octubre 8 de 2014

Impreso y hecho en Colombia

Printed and made in Colombia 


\section{Contenido}

Agradecimientos ..................................................... 9

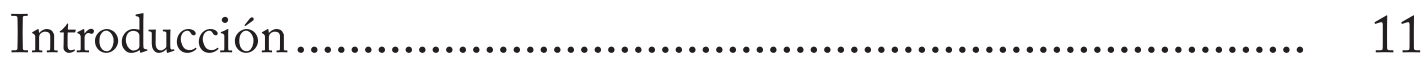

1. Aproximación a los estudios sobre clientelismo en Colombia: análisis de la matriz metodológica ............. 15

2. Enfoques teóricos de los estudios sobre clientelismo en Colombia............................................................. 25

2.1. Funcionalismo ……............................................. 26

2.2. Enfoque marxista ................................................. 28

2.3. Enfoque estructural-funcionalista ............................ 31

2.4. Enfoque neo-institucionalista ................................. 34

2.5. Enfoque socio-antropológico ……………………..... 38

3. Tipologías de clientelismo .............................................. 47

3.1. Clientelismo tradicional ........................................ 48

3.2. Clientelismo moderno .............................................. 49

3.3. Clientelismo de mercado ......................................... 51

4. Modernidad, capitalismo y democracia: tres debates a propósito del clientelismo ............................................. 55

4.1. El clientelismo, ¿fenómeno moderno o premoderno? 55 
4.2. ¿Clientelismo como producto de la modernidad o como contradicción a la misma? .......................... 58

4.3. Clientelismo y democracia, ¿un imposible? ............. 63

5. Análisis político sobre la emergencia de los estudios de clientelismo ........................................................... 67

5.1. Frente Nacional .................................................. 68

5.2. Crisis del bipartidismo ......................................... 71

5.3. Modernización y reforma del 68 .......................... 73

5.4. Constitución de 1991 ........................................... 75

6. ¿Clientelismo como desviación de la política o como forma de representación? ............................................... 79

6.1. Clientelismo como desviación ................................ 80

6.2. Clientelismo como representación......................... 83

7. La emergencia del clientelismo como objeto visible del sistema político y la preeminencia de la visión negativa del fenómeno ............................................... 85

7.1. Propagación del clientelismo y del discurso anti-clientelista

Conclusiones

Bibliografía

Anexos. 


\section{Agradecimientos}

Doy gracias a la Universidad del Rosario por abrir los espacios de discusión y formación del pensamiento crítico que permitieron forjar un primer boceto de los planteamientos abordados a lo largo del presente trabajo; y así mismo, por hacer posible su publicación. La idea de ahondar en el tema de comportamientos políticos que se trasladan del pasado al presente, nació en primera instancia en una electiva conocida como Patrimonio Cultural, en ese entonces a cargo del profesor Pedro Eliseo Sánchez. Sin embargo, los desarrollos que nacieron de esa primera noción, no habrían sido los mismos de no ser por los debates abiertos que se dieron en clase de Hacienda y Presupuesto Público, a cargo del profesor Germán Puentes, y la iluminación que acarreaba cada dosis de teoría recargada de Política y Sociedad, en manos del maestro Rubén Sánchez David. Me gustaría citar palabras del profesor Puentes cuando nos recordó que la universidad no es otra cosa que la posibilidad de reunión de un grupo de personas, que se sientan a discutir y producir ideas alrededor de una sola problemática.

A los guías metodológicos: A Rocío Rubio Serrano, antropóloga de la Universidad de los Andes, especialista en el tema de conflicto armado y clientelismo, quien fue una guía que de manera constante y dedicada acompañó paso a paso este proceso y aportó el enfoque original y diferencial a este trabajo; y a Javier Cárdenas, profesor de metodología, quien fue inmensamente colaborador en el proceso de formulación del proyecto. 
En esta lista interminable de personas e instituciones que de manera tranquila abrieron sus bibliotecas a lectores curiosos, hay dos maestros de la vida a los que no puedo dejar de hacer referencia: Mi madre, incondicional compañera y maestra de metodología, Bárbara García Sánchez; y mi padre, guía y maestro de historia, Javier Guerrero Barón. Esta tesis es el producto de una carrera y de una búsqueda incansable de respuestas, la mayoría de ellas todavía inconclusas, que nacieron en la mesa del comedor de casa y se desarrollaron posteriormente en la academia.

A Paula Kamila Guerrero y Nem Zuhue Patiño García, por su complicidad, mezclada con un poco de picardía, en la consecución del material bibliográfico de la Universidad de los Andes. Sin ellos, el trabajo no habría sido fácil y tampoco tan divertido como lo fue. Finalmente, gracias a Néstor Miranda Ontaneda, cuyos trabajos desarrollados a propósito del clientelismo político han sido una fuente de curiosidad y de próximas investigaciones. 


\section{Introducción}

El clientelismo politico en Colombia, desde hace unas cuatro décadas, se ha venido configurado como objeto de estudio de antropólogos, sociólogos, historiadores y politólogos, incluso, se ha configurado como materia de discusión de periodistas y abogados. Los escándalos de corrupción en instituciones públicas, asociados erróneamente con el clientelismo, han suscitado el interés de muchos estudios de caso, que corroboran la existencia de racionalidades útiles a quienes detentan el poder, pero ineficientes dentro de las lógicas de un Estado moderno regido por la trasparencia, meritocracia y la participación ciudadana en defensa de lo público. De acuerdo con Jesús Duarte, el mal funcionamiento de las instituciones públicas es un aspecto que evidencia la ineficiencia estatal y hace del clientelismo no un mero problema administrativo, sino también político, cultural y comportamental. ${ }^{1}$ Comprenderlo sin judicializarlo, satanizarlo o patologizarlo puede contribuir a desarrollar mecanismos democráticos que adopten viejas formas de hacer política en el país.

La capacidad de adaptación del clientelismo a los cambios institucionales obliga a revisar las reformas más significativas al régimen político. Por ende, el presente estado del arte se aproxima al clientelismo político en Colombia desde 1973 hasta 2011. Su objetivo es identificar rupturas y continuidades en el abordaje del fenómeno, a partir de enfoques, tipologías, debates y momentos

${ }^{1}$ Comparar Jesús Duarte, Educación pública y clientelismo en Colombia (Medellín: Universidad de Antioquia, 2003), 29. 
históricos claves resaltados en los estudios sobre el fenómeno. La hipótesis desde donde se partió en este trabajo identificaba dos aproximaciones al clientelismo. La primera consideraba al fenómeno una desviación de la política y amenaza al funcionamiento democrático. Mientras que la segunda lo abordaba como una característica funcional del sistema, como una forma de participación y representación política, e incluso, como un modo de distribución de lo público en un colectivo. ${ }^{2}$ En la medida en que se tuvo una aproximación más compleja al tema, se encontró que, si bien se puede encontrar un viraje en la forma de aproximarse al fenómeno a partir de la década de los años noventa, era difícil sostener la categorización de las obras en estas dos categorías. Sin embargo, el presente texto profundiza en estos dos tipos de aproximación, los cuales fueron identificados a partir de las mismas formas de enunciación utilizadas por los autores.

El ejercicio realizado configuró un corpus de 72 fuentes académicas, desde 1973 hasta 2011, que comprenden libros, capítulos de libros, artículos de revistas académicas y tesis, principalmente de maestría y doctorado. Estas fueron seleccionadas dentro de un universo más amplio que, dado el alcance y límites de este trabajo, no se referencia en su totalidad. El criterio de selección consistió tanto en la frecuencia con la que las obras fueron citadas como en sus aportes teóricos y contextuales a propósito de las reformas institucionales de la época.

La metodología de trabajo consistió en la construcción de una matriz metodológica (ver anexo 1), que agrupó las fuentes por año de publicación, enfoque teórico, unidad de análisis e hipótesis. La sistematización de la matriz fue complementada con

\footnotetext{
${ }^{2}$ Comparar Francisco Gutiérrez Sanín, “Clientelismo y sus enredos”, en La ciudad representada: política y conflicto en Bogotá (Bogotá: TM Editores, 1998), 55-120.
} 
la elaboración de 300 fichas bibliográficas que cumplieron el papel de Raes (Resumen Académico Especializado). En estas se extrajeron las tesis centrales de cada trabajo (ver anexo 2).

A continuación, el lector se encontrará con un balance a propósito de los estudios sobre clientelismo, estructurado a partir de siete capítulos. En el primero, se narra la emergencia de las obras analizadas y su importancia en términos teóricos, al igual que se realiza una descripción cuantitativa de las fuentes utilizadas. En el segundo, se hace una descripción de los marcos teóricos empleados en los estudios sobre clientelismo. En el tercero, se presenta la tipología empleada para clasificar el fenómeno y sus debates. El cuarto capítulo es una exposición de los principales debates que se han generado a propósito del fenómeno. En el quinto se efectúa un análisis del contexto histórico-político colombiano, referente obligado para la comprensión de la emergencia del clientelismo como objeto visible y problemático del sistema. En el sexto se describen dos aproximaciones hegemónicas al fenómeno: la visión negativa del mismo y la mirada en clave positiva. Se finaliza el ejercicio con un sexto capítulo que genera una hipótesis de trabajo acerca de la emergencia del clientelismo como objeto visible del sistema político y la preeminencia de la visión negativa. Finalmente, en el séptimo capítulo se procede a dar las conclusiones de este estado del arte. 



\section{Aproximación a los estudios sobre clientelismo en Colombia: análisis de la matriz metodológica}

Este capítulo describe las fuentes analizadas sobre el clientelismo político en Colombia, explicando su ubicación temporal e importancia teórica. Identifica, además, la existencia de diferentes enfoques y formas de aproximación al fenómeno.

La década del setenta es el punto de partida, momento en el que se observa una recurrencia en el empleo del término "clientelismo" en remplazo de otras categorías como las de "caudillismo", "caciquismo"y "patrimonialismo". En esta década, los estudios de clientelismo se caracterizaron por tomar fuerza tanto en Europa como en los Estados Unidos de Norte América, EE. UU., dando lugar a debates entre enfoques que, por supuesto, llegaron a Colombia y se manifestaron en las perspectivas y problemáticas abordadas.

En el país, los estudios sobre clientelismo representan un corpus de producción académica sostenida desde $1974 .{ }^{3}$ En este año, el Centro de Investigaciones y Educación Popular, Cinep, emprendió una serie de esfuerzos académicos con el fin de "indagar por las bases socioeconómicas del comportamiento político en el agro

${ }^{3}$ Comparar Fernán E. González, "Clientelismo y administración pública”, Enfoques colombianos, (1980): 68 . 
Colombiano"4 a partir del análisis teórico y los estudios de caso regionales. Este trabajo, liderado por Néstor Miranda Ontane$\mathrm{da},{ }^{5}$ se enmarcó en el enfoque marxista, perspectiva desde la cual se pretendía superar las dificultades del enfoque funcionalista. ${ }^{6}$

Lo expresado no niega la existencia de estudios anteriores: en 1973 se puede localizar el antecedente internacional más cercano en la tesis doctoral de Steffen Walter Schmidt en la Universidad de Columbia. ${ }^{7}$ Walter Schmidt revisó el sistema político colombiano y consolidó un marco conceptual sobre el clientelismo, introducido al tema por Orlando Fals Borda y León Bramson. ${ }^{8}$ Además de esta obra y de las publicaciones del Cinep, para la época se contó con otros aportes históricos, teóricos y sociológicos de autores

${ }^{4}$ Ver Fernán E. González, "Aportes al diálogo entre historia y ciencia política. Una contribución desde la experiencia investigativa en el Cinep”(Historia Crítica, 2004), 28.

${ }^{5}$ Comparar Néstor Miranda Ontaneda, Clientelismo y dominio de clase (Bogotá: Cinep, 1977).

${ }^{6}$ Miranda Ontaneda llegó a Colombia luego de publicar en Bamberg Klientelismus und koloniale Abhängigkeit. Eine ethnosoziologische Analyse d. Repartimiento-Encomienda-Systems aufd.Antillen, 1492-1525 (El clientelismo y la dependencia colonial: Un análisis etno-sociológico del sistema de repartimiento-encomienda de las Antillas, 1492-1525) (Bamberg: Heidelberg, 1968). Entre 1975 y 1978 dirigió una investigación en el Cinep que buscaba romper con el enfoque ahistórico y funcionalista de la época. Cuatro publicaciones con estudios de caso, de corte marxista, fueron el resultado. Estos asumían al clientelismo como un mecanismo de instrumentalización del ser humano para la conservación del poder de las élites políticas. Su importancia radicó en la inscripción del país en un tema en furor en Europa y EE. UU. y en la aplicación rigurosa de un marco teórico para la realidad colombiana. Los cuatro estudios fueron el de Alejandro Reyes, Latifundio y poder politico (Bogotá: Cinep, 1978); el de Eloísa Vasco Montoya, Clientelismo y minifundio (Bogotá: Cinep, 1978); el de Jorge Ramírez Valenzuela, Producción arrocera y clientelismo (Bogotá: Cinep, 1978); y la compilación de artículos publicados por la Fundación Friedrich Naumann, compilados por Néstor Miranda Ontaneda, Clientelismo (Bogotá: Fundación Friederich Naumann, 1980).

${ }^{7}$ Comparar Steffen Walter Schmidt, "Political Clientelism in Colombia" (tesis de doctorado, University Microfilms International, Londres, 1972).

${ }^{8}$ Sociólogo profesor de la Universidad de Harvard. 
nacionales tales como Fernando Guillén Martínez y de escuelas anglosajonas entre cuyos representantes se puede citar a Malcolm Deas, Frank Safford y Catherine LeGrand. ${ }^{9}$ Así, el clientelismo empezó a ser objeto de estudio en Colombia a partir de los años setenta, de manera paralela a los estudios del clientelismo europeos y estadunidenses. Se trata de una historia conectada y concomitante, cuyo agente difusor fue, sin duda, Miranda Ontaneda.

La producción de los setenta se caracterizó por estar enmarcada dentro de los enfoques funcionalista y marxista. Los principales voceros fueron Steffen Walter Schmidt ${ }^{10}$ y Néstor Miranda Ontaneda. Las variables empleadas respondían a una trasformación del sistema político colombiano. De ahí que estos trabajos abordaron el problema desde: i) la observancia de la burocracia aplicada al régimen del Frente Nacional; ii) el sistema productivo agrario de la época; iii) el desarrollo de la economía capitalista; y iv) el problema del poder político manejado por las élites bipartidistas.

En la década de los ochenta se presentó una explosión de estudios de caso sobre clientelismo. Así, los esfuerzos del Cinep dieron sus frutos en forma de estudios regionales marxistas, dentro de los cuales están los trabajos de Eloísa Vasco, Alejandro Reyes, Jorge Ramírez, Mario Alviar, Fernán González, Jaime Arocha, Jaime Echavarría y Julio Hálaby y Eduardo Díaz. ${ }^{11}$ Su aporte fue

${ }^{9}$ Comparar Fernán. E. González, "Aportes al diálogo entre historia y ciencia política. Una contribución desde la experiencia investigativa en el Cinep"(Historia Crítica, 2004), 29.

${ }^{10}$ Comparar Steffen W. Schmidt, "Bureaucrats as Modernizing Brokers? Clientelism in Colombia"(Comparative Politics 6, 1974), 425-450 y Steffen W. Schmidt, "Political Clientelism in Colombia" (1972).

${ }^{11}$ Comparar Jaime Arocha, "Clientelismo, gasteo y violencia”, Enfoques colombianos, (1980); Fernán González, “Clientelismo y administración pública”, Enfoques colombianos, (1980); Mario Alviar, "Clientelismo y Participación política”, Enfoques colombianos, (1980); 
significativo para la comprensión del funcionamiento del poder local, en regiones como Sucre, Quindío, Chocó y Boyacá.

Para finales de los años ochenta aparecieron enfoques que antes de preguntarse por las relaciones de explotación del campesinado, causadas por las formas de producción pre-capitalista, se cuestionaban por el problema de la democracia en Colombia. En este contexto y con una mirada más institucionalista, Rodrigo Losada introdujo la problemática del voto clientelista en las elecciones populares, ${ }^{12} \mathrm{y}$ John Sudarsky abordó la desigualdad del ingreso desde la formación de cooperativas. ${ }^{13}$ Desde entonces, el sistema político colombiano, la crisis de los partidos políticos y los cambios institucionales producidos, a partir de las reformas de 1968 y 1991, pasaron a ser el centro de atención de los autores.

En los años noventa, la obra de Francisco Leal y Andrés Dávila, ${ }^{14}$ desde un enfoque estructural-funcionalista, marcó un hito en el abordaje del clientelismo al comprenderlo como el articulador de todo el sistema político colombiano y no sólo como un mecanismo que instrumentalizaba individuos en función de votos y favores. Con la vigencia de la Constitución de 1991, se presentó una explosión de estudios institucionalistas y con enfoques anclados a la cultura política, a partir de los cuales se empezarían

Néstor Miranda Ontaneda, "El poder político en Colombia”, Enfoques Colombianos, (1980); Eduardo Díaz Uribe, El clientelismo en Colombia: Un estudio exploratorio (Bogotá: Áncora Editores, 1986); Jaime Echavarría Córdoba, y Julio C. Hálaby Córdoba, Sociología politica de comicios y clientelismo (Chocó: Universidad Tecnológica del Chocó, 1988).

${ }^{12}$ Comparar Rodrigo Losada Lora, Clientelismo y elecciones: tres modelos explicativos del comportamiento electoral colombiano (Bogotá: Pontificia Universidad Javeriana, 1984).

${ }^{13}$ Comparar John Sudarsky, Clientelismo y desarrollo social (Bogotá: Tercer Mundo Editores, 1988).

${ }^{14}$ Comparar Francisco Leal Buitrago y Andrés Dávila Ladrón de Guevara, Clientelismo, el sistema político y su expresión regional (Bogotá: Tercer Mundo Editores, 1991). 
a abordar otros aspectos del clientelismo tales como: la participación, la representación y la formación de ciudadanía. Dichos estudios estarían liderados por autores tales como Francisco Gutiérrez Sanín, Andrés Dávila, Miguel García y Rocío Rubio. ${ }^{15}$

En este recorrido se observa que desde finales de la década de los ochenta hay una apertura a examinar el clientelismo desde diferentes enfoques (funcionalista, marxista, estructural-funcionalista, el socio-antropológico, con anclajes en la cultura política, y el institucionalista). Estos observan al fenómeno como modo de distribución de bienes y servicios, ${ }^{16}$ forma de participación y representación; ${ }^{17}$ o bien como la peor deformación de la democracia, antesala de la corrupción política ${ }^{18}$ y producto de la crisis de los partidos tradicionales. ${ }^{19}$

\footnotetext{
${ }^{15}$ Comparar Francisco Gutiérrez Sanín, “Clientelismo y sus enredos”; Andrés Dávila Ladrón de Guevara, "Clientelismo, intermediación y representación política en Colombia: ¿Qué ha pasado en los noventa?” (Estudios Políticos, 1999); Miguel García Sánchez, ¿Ciudadanía avergonzada? Democracia local y construcción de ciudadanía en Bogotá (Bogotá: Universidad de los Andes y Universidad Nacional de Colombia, 2003); y Rocío Rubio Serrano, No hay paraísos sino los perdidos: Historia de una red clientelista en Bogotá (Bogotá: Universidad Nacional de Colombia, 2003).

${ }^{16}$ Duarte, Educación.

${ }^{17}$ Comparar Fernando Escalante, "Clientelismo y ciudadanía en México: apuntes sobre la conceptualización de las formas de acción política” (Analisis Político, 1995).

${ }^{18}$ Comparar Roll, David Alberto, "El clientelismo: corrupción a tres bandas”, Sindéresis, (2000), 114-128.

${ }^{19}$ Comparar John D. Martz, The Politics of Clientelism: Democracy E the State in Colombia (New Brunswick, New Jersey: Transaction Publishers, 1997).
} 


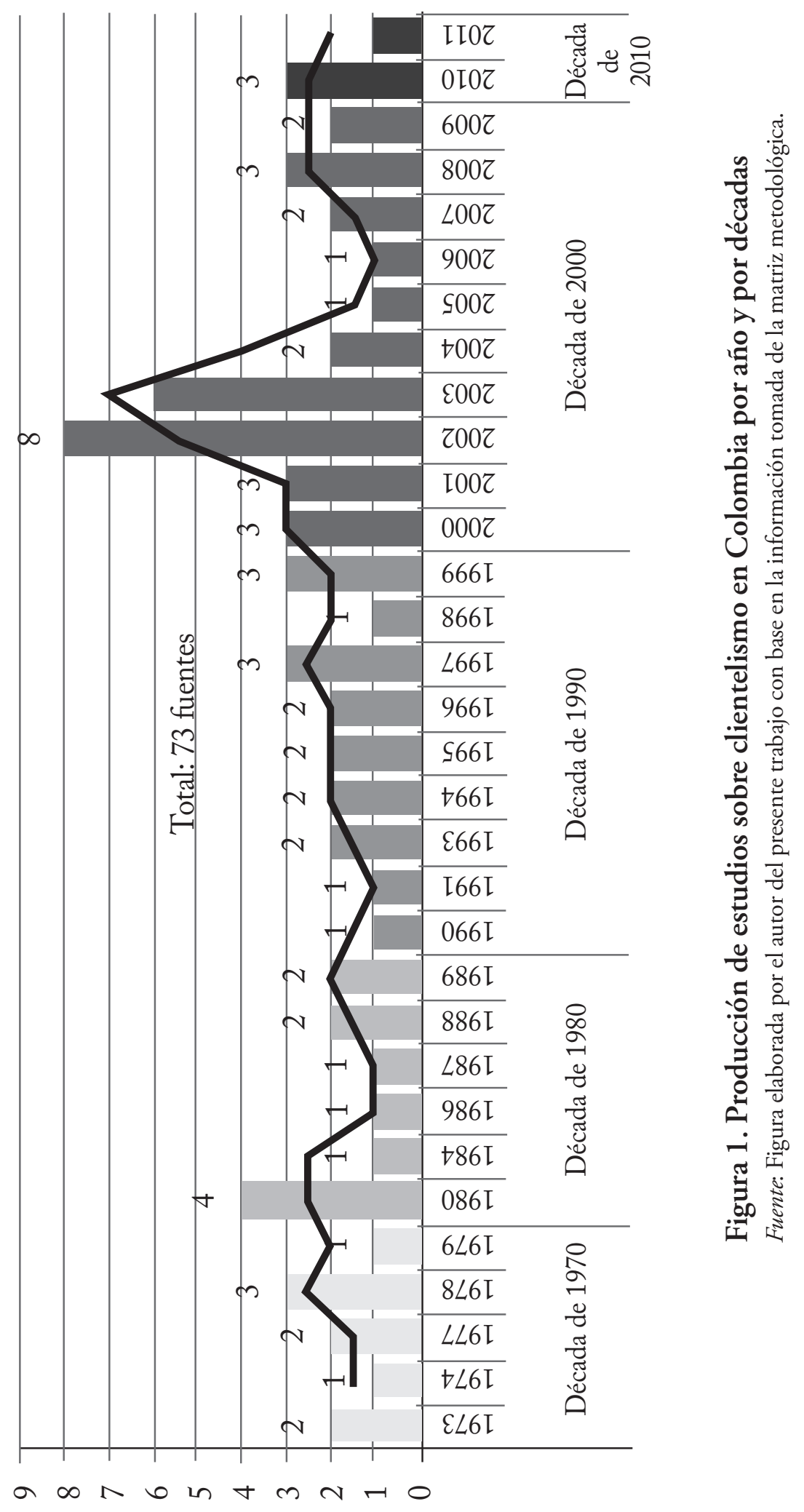


Adicionalmente, la matriz metodológica, elaborada para dar cuenta de este estado del arte (ver anexo 3), indica a manera de conclusión que en Colombia aparecieron los estudios pioneros sobre clientelismo en la década de los setenta. En la siguiente década, se observa un terreno fértil para los estudios regionales de caso. Desde 1993, se identifica que hay una tendencia a producir anualmente al menos un trabajo sobre clientelismo. Entre el 2002 y el 2003, evidencia la máxima producción de las cuatro décadas revisadas (ver figura 1). Por último, señala un declive de los estudios sobre clientelismo a partir de la segunda década del siglo xxI.

Los hallazgos de la matriz permiten establecer que en la década de los setenta los dos enfoques predominantes fueron el marxista y el funcionalista, teniendo en cuenta que el estructuralismo representa una vertiente del marxismo. Una década más tarde, se observó la desaparición del enfoque funcionalista y el auge del enfoque marxista. Simultáneamente, se mantuvo constante la cantidad de estudios de corte institucionalista, a la vez que emergió tímidamente la perspectiva socio-antropológica.En los noventa se observó un declive en el empleo del enfoque marxista; no obstante, algunas de sus ideas siguen prevaleciendo, lo que ha evitado su completa desaparición. El enfoque hegemónico en esta década fue el institucionalista; por otro lado, el estructural-funcionalista mostró sus primeras apariciones, mientras que el enfoque socio-antropológico mostró un ligero incremento. Para comienzos del siglo xxi, el enfoque predominante fue el institucionalista, le siguió el socio-antropológico y el estructural-funcionalista, pese a que se presentaron eventuales trabajos desde el enfoque marxista. 


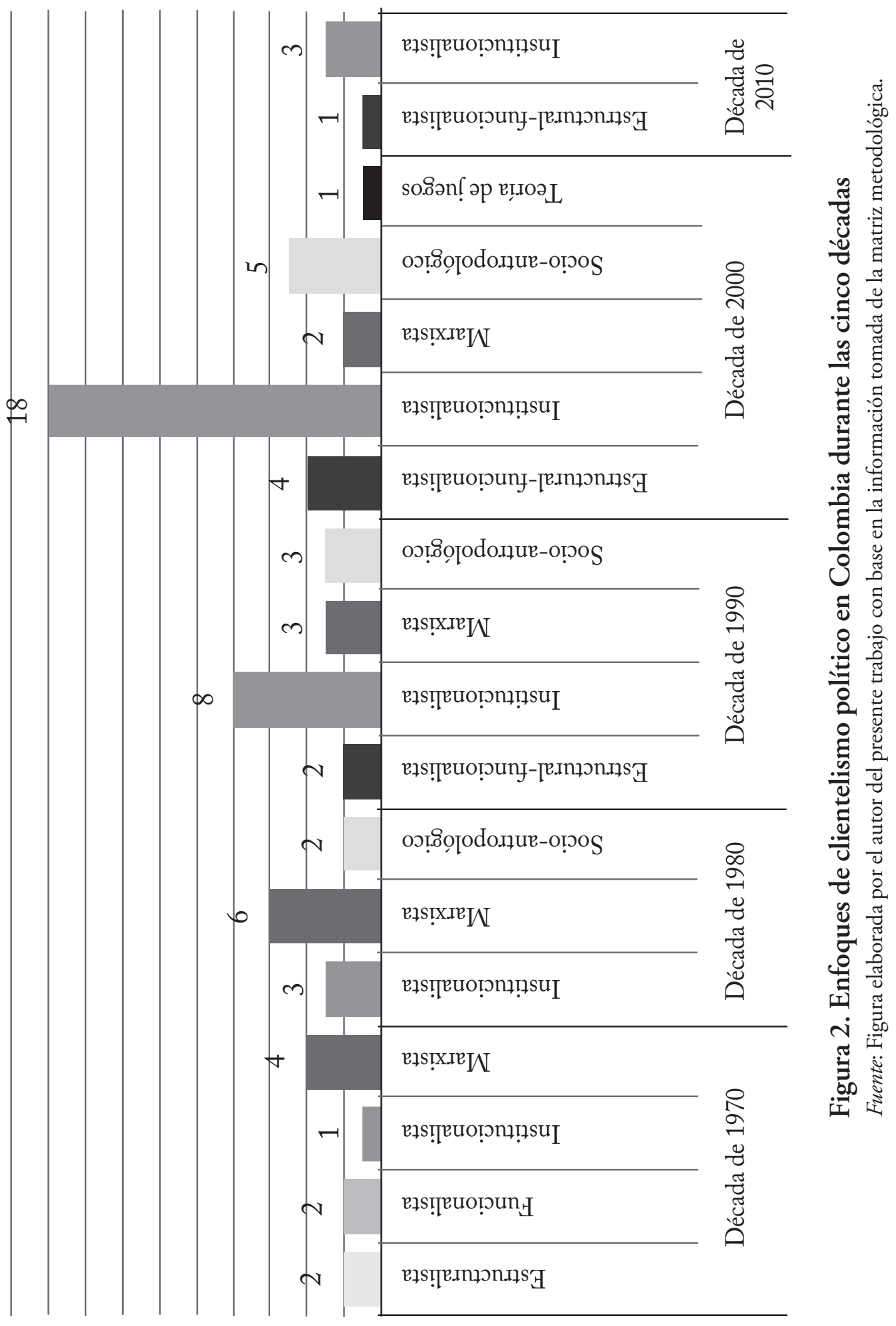


Identificar los límites teóricos de cada trabajo es una tarea que requiere claridad sobre los enfoques, ya que no todos los autores manifiestan explícitamente sus adscripciones. Sin embargo, las categorías enunciadas y los argumentos presentados son la primera clave para evidenciar el marco conceptual soporte de cada estudio. Este ejercicio se realizó, en un primer nivel de análisis, en la construcción del presente estado del arte.

A continuación, además de explicar los criterios de clasificación de las obras, se buscará hacer una exposición de las trasformaciones de cada enfoque teórico, así como de una serie de eventos diagnósticos que alimentaron la discusión a propósito del tema. Vale la pena aclarar que la selección de los eventos diagnósticos que se presentan a continuación es producto de la literatura revisada. Finalmente, se pretende mostrar el cambio que ha sufrido la forma de abordar el fenómeno en Colombia. 



\section{Enfoques teóricos de los estudios sobre clientelismo en Colombia}

Los cambios políticos de las últimas décadas impactaron no sólo al Estado, sino también a las concepciones de las ciencias sociales sobre lo público, la democracia, la ciudadanía, la participación, la transparencia y la corrupción, entre otros aspectos. De estos cambios, surgió una redefinición del clientelismo político, menos ingenua y más compleja. Las viejas concepciones funcionalistas, marxistas e institucionalistas se han redefinido y, en algunos casos, entrelazando eclécticamente, dando lugar a la emergencia de nuevas categorías analíticas.

Este capítulo da cuenta de los principales supuestos teóricos que guiaron los diferentes estudios sobre clientelismo. Su derrotero es reseñar las ideas de las que partieron los textos, en su momento, mas no hacer un tratado sobre las trasformaciones de cada enfoque desde sus orígenes hasta nuestros días.

Se observa que existe una concordancia entre los siguientes tres elementos: i) la preeminencia que tuvo cada enfoque a lo largo de las décadas estudiadas; ii) el contexto histórico-político; y iii) las tipologías sobre clientelismo empleadas por la literatura estudiada. ${ }^{20}$ Sobre este último punto, se identifican tres tipos de

${ }^{20} \mathrm{El}$ contexto será abordado en el cuarto capítulo y las tipologías en el tercero. 
clientelismo: i) el tradicional, ii) el moderno; y iii) de mercado. ${ }^{21}$ Cada tipo tiene unas características particulares que: hacen referencia a un tiempo determinado; interactúan con marcos conceptuales específicos; y con debates en boga en cada momento histórico.

\subsection{Funcionalismo}

La discusión teórica sobre clientelismo nació, en parte, de la distinción de los conceptos de comunidad y sociedad planteadas por Fernando Tönnies, Max Weber y Talcott Parsons. ${ }^{22}$ En los años sesenta, un grupo de antropólogos se interesó por el estudio de estructuras sociales definidas como arcaicas, tomando distancia de los énfasis evolutivos de la época. ${ }^{23}$ Los temas del desarrollo, la modernidad y el capitalismo fueron los problemas prioritarios para abordar la relación entre el clientelismo y las sociedades arcaicas.

El marco analítico de estos estudios fue el funcionalista, que desplazó conceptos biológicos al campo de las ciencias sociales. La sociedad fue descrita, entonces, como un organismo compuesto por partes, que tendían a adaptarse a las condiciones del ambiente: el grado de adaptación de las partes, por ende, definía la naturaleza funcional o disfuncional de los subsistemas. ${ }^{24}$ Las sociedades rurales fueron, preferencialmente, la unidad analítica

${ }^{21}$ Estas categorías ad hoc han sido construidas por diferentes autores. Comparar Andrés Dávila Ladrón de Guevara y Natalia Delgado Valera, "La metamorfosis del sistema político colombiano: ¿Clientelismo de mercado o nueva forma de intermediación?”, en Degradación o cambio: Evolución del sistema politico colombiano, compilado por Francisco Gutiérrez Sanín (Bogotá: Editorial Norma, 2002), 319-356.

${ }^{22}$ Comparar Miranda Ontaneda, Clientelismo y dominio de clase, 1.

${ }^{23}$ Comparar Duarte, Educación, 2.

${ }^{24}$ Comparar David L. Sills y otros. "Variedades de análisis funcional”, en Enciclopedia Internacional de las Ciencias Sociales (Madrid: Editorial Aguilar, vol. I, 1974), 305. 
y el microanálisis fue la metodología más empleada. Los principales hallazgos fueron el carácter diádico y las relaciones cara a cara del clientelismo. ${ }^{25}$

Para el enfoque funcionalista, la estructura social, por definición asimétrica, es una urdimbre de roles desempeñados por individuos. Allí, toda relación diferente a la familia nuclear se configura contractualmente. ${ }^{26}$ En este contexto, el clientelismo fue asumido como un contrato personal, de libre asociación e informal entre dos individuos, con diferente estatus pero con una contraprestación recíproca. ${ }^{27}$ Las tres relaciones que señalaba el enfoque en función de la estructura social (piramidal y jerárquica) eran: i) la relación patrón-cliente $(\mathrm{P}-\mathrm{C})$; ii) la relación patrón-patrón ( $\mathrm{P}-\mathrm{P})$; y iii) la relación cliente-patrón (C-P).$^{28} \mathrm{~A}$ partir de estos tipos de relaciones se crearon modelos para determinar la cantidad, la naturaleza y la calidad de las prestaciones y contraprestaciones entre los actores. Los teóricos que nutrieron este enfoque fueron, entre otros, Fernando Tonnies, Max Weber, Talcott Parsons, Mauss, Malinovski, Richard Thurwald, Redfild y Boscof. ${ }^{29}$

Tras su auge, el enfoque funcionalista mostró sus limitaciones analíticas. Las críticas cuestionaban el énfasis en unidades micro, cuando estas tienen conexiones o dependencias con centros de poder más amplios y los vínculos simples entre individuos sin complejidad y sin contexto. La respuesta funcionalista fue la

\footnotetext{
${ }^{25} \mathrm{El}$ concepto de contrato diádico hace referencia a un tipo específico de vínculo que se establece entre dos individuos con diferente estatus.

${ }^{26}$ Comparar Miranda Ontaneda, Clientelismo, 4.

${ }^{27}$ María Clara Torres Bustamante, El fenómeno del clientelismo político: Visión de los funcionalistas y de los marxistas, consultado octubre 15,2012, http://www.institut-gouvernance.org/es/analyse/fiche-analyse-43.html.

${ }^{28}$ Comparar Miranda Ontaneda, Clientelismo, 6.

${ }^{29}$ Comparar Fernán E. González, "Clientelismo”, 69.
} 
introducción de nociones tales como la de bróker, intermediario o mediador, al igual que el análisis de redes y triadas y los estudios de grupos de poder y de partidos.

En Colombia, son pocas las obras que se inscriben exclusivamente en el enfoque funcionalista. Una de ellas es la ya citada de Steffen Walter Schmidt sobre el sistema bipartidista en 1972. Este autor estableció las formas básicas de operación y los rasgos característicos de las relaciones $\mathrm{P}-\mathrm{C}$ en Colombia. ${ }^{30}$

$\mathrm{El}$ debate académico nacional reconoce que el enfoque funcionalista fue el punto de partida para los estudios de clientelismo colombiano. No obstante, las discusiones se han centrado en señalar sus límites. Ronald Archer, por ejemplo, sostiene que en la relación patrón-cliente, la asociación del patrón con grandes propietarios y del cliente con campesinos sin tierra se prestan para interpretar que la trasformación social de los roles da por terminada la relación clientelista, lo cual es erróneo. ${ }^{31}$

No en vano, desde el enfoque funcionalista el clientelismo fue asumido como un problema que tendería a desaparecer con la llegada del desarrollo. Sin embargo, pese a las transformaciones del país y su inserción económica en el mundo capitalista, el clientelismo persiste, se reproduce, se transforma y se adapta a los cambios institucionales.

\subsection{Enfoque marxista}

El enfoque marxista abordó el clientelismo al advertir que este no era un asunto exclusivo de sociedades atávicas e indicó que eran

\footnotetext{
${ }^{30}$ Comparar Schmidt, "Political Clientelism".

${ }^{31}$ Comparar Archer, Ronald P. The Transition from Traditional to Broker Clientelism in Colombia: Political Stability and Social Unrest (Notre Dame, Indiana: Kellogg Institute for International Studie, 1990), 6-7.
} 
las relaciones de producción las que explicaban cómo y a favor de quién funcionaba el sistema. ${ }^{32}$ De ahí que le imprimiera al análisis una perspectiva histórica y de clase en situaciones socioeconómicas concretas.

Este enfoque describió al clientelismo como un modo de obrar político y una transacción bajo las reglas del dar y recibir, que puede ser traducida en "dar un poco de poder a quien le hace falta”. ${ }^{33}$ En consecuencia, el clientelismo fue definido en términos de instrumentalización de una clase, dueña de los medios de producción político-económicos, sobre otra desprotegida a la que se le saca el mayor beneficio; en síntesis, un modo de explotación del hombre por el hombre. ${ }^{34}$

Miranda Ontaneda abordó, por primera vez, el problema del clientelismo en Colombia desde una perspectiva teórica marxista. Su trabajo tomó las tesis del clientelismo como una relación diádica presente en la perspectiva funcionalista. ${ }^{35}$ También, Miranda se apoyó en la obra de Guillén Martínez, ${ }^{36}$ quien realizó una génesis del clientelismo a partir de categorías que tomaron distancia de las weberianas ${ }^{37}$, para proponer un análisis de las

${ }^{32}$ Comparar González, “Clientelismo”, 69.

${ }^{33}$ Ver Miranda Ontaneda, Clientelismo, 20.

${ }^{34}$ Comparar Nicolás Jaramillo, Clientelismo y poder: relectura crítica de algunas reflexiones hechas sobre el clientelismo en Colombia (Bogotá: Universidad Nacional de Colombia, Facultad de Derecho, Ciencias Políticas y Sociales, 2005), 15.

${ }^{35}$ Los postulados teóricos elaborados por Miranda Ontaneda sirvieron de sustento teórico para la gran mayoría de obras enmarcadas en la teórica marxista. Fue a partir de este marco que se elaboraron los estudios de caso regionales publicados en 1980.

${ }^{36}$ Comparar Fernando Guillén Martínez, El poder político en Colombia, (Bogotá: Punta de lanza, 1979). La primera versión en mimeógrafo fue circulada internamente por el Centro de Investigaciones para el Desarrollo (CID) de la Universidad Nacional en 1973.

${ }^{37}$ Guillén Martínez hace una propuesta desde la historia integral y la sociología interpretativa a partir de categorías como las de tipos construidos. Su propuesta es difícil de 
formas de asociación presentes en la historia colombiana tales como: la encomienda, la hacienda y el sindicalismo. Así, señaló que tales formas de agrupación se articularon como mecanismos sutiles pero efectivos de dominación de las élites, que se trasladaron a la esfera política vía los dos partidos tradicionales y se reprodujeron a partir de lógicas clientelistas en el nivel burocrático. ${ }^{38}$

Los estudios marxistas del clientelismo, como se anotó anteriormente, aportaron una perspectiva histórica y de clase social al análisis del mismo. Desde esta postura, las relaciones de patronazgo presentes en el campo absorben las formas de producción capitalista, produciendo un biato cultural que hunde al país en un estado de producción pre-capitalista y pre-moderno. ${ }^{39} \mathrm{E} 1$ clientelismo es un mecanismo de dominación de las élites que permite reproducir y mantener las lealtades verticales e impedir la creación de asociaciones en su sentido horizontal. ${ }^{40}$

Sin embargo, cuando el clientelismo manifestó ser un fenómeno que también podía darse entre clases y en todas direcciones, los postulados marxistas perdieron alcance y capacidad explicativa. Además, su referencia a grandes estructuras, partidos, clases, el Estado, cuya figura central era casi exclusivamente el terrateniente

clasificar en un enfoque, sin embargo es claro que sus postulados son insumo fundamental para las vertientes institucionalista, marxista y estructural-funcionalista. En esta oportunidad se clasificó a Guillén dentro del enfoque estructuralista debido a que su tesis se fundamenta en la existencia de estructuras de larga duración adscriptivas desde la encomienda y la hacienda, las cuales instauraron formas de poder establecidas desde el periodo colonial hasta el momento de la escritura del texto.

${ }^{38}$ Néstor Miranda Ontaneda, "El poder político en Colombia", Enfoques colombianos, (1980): 39.
${ }^{39}$ Comparar Jorge Valenzuela Ramírez, Producción, 35.
${ }^{40}$ Comparar Miranda Ontaneda, "El poder”, 46. 
o el gamonal o cacique, impedían su efectividad y aplicabilidad. ${ }^{41}$ De otra parte, la idea de un "pre-capitalismo" agrario anacrónico le restó vigencia y capacidad explicativa sobre la naturaleza del campesinado y sus articulaciones con el capitalismo urbano. Actualmente, este enfoque se ha trasformado y su campo de análisis ha migrado a otros asuntos tales como el sindicalismo, los movimientos sociales, los análisis de grupo y de género, entre otros.

\subsection{Enfoque estructural-funcionalista}

Este enfoque comparte con el funcionalista la herencia de conceptos de las ciencias naturales con modificaciones sustanciales al trascender la biología y ver la sociedad como un gran sistema articulado por subsistemas. Con ello va más allá de la explicación del funcionamiento interno de la unidad para entender cómo se relaciona esta con un entorno mucho más amplio. Desde esta perspectiva, los conceptos de estructura social, de sistema, de función, rol, estatus y de proceso adquieren un papel central: "La estructura social es la trama de posiciones e interrelaciones mutuas mediante las cuales se puede explicar la interdependencia de las partes que conforman la sociedad. La función de cada parte es la forma en que esa parte opera para mantener el sistema total en buena salud". ${ }^{42}$

En Colombia, Leal y Dávila adoptan este enfoque para superar las dificultades analísticas de los trabajos precedentes sobre clientelismo. Su investigación articuló el macro-análisis con el micro-análisis, explicando el funcionamiento del sistema político colombiano a partir de la comprensión de su unidad más pequeña: el municipio y de su articulación con el sistema en su conjunto. En este contexto, el clientelismo se describe como aquello que

\footnotetext{
${ }^{41}$ Martz, The Politics, 14.

${ }^{42}$ Ver Sills y otros, Enciclopedia, vol. I, 299.
} 
“[...] comanda al conjunto de relaciones sociales que definen la forma real como opera la política (sistema), a partir de las normas establecidas para el efecto por el Estado (régimen). El Estado, a su vez, expresa la organización de las relaciones de poder en la sociedad, materializadas en un conjunto de instituciones administradas por los gobiernos". ${ }^{43}$

Los autores plantearon que el clientelismo se convirtió en una relación fundamental para el sistema político tras el Frente Nacional. En este período, los partidos tradicionales se apoyaron en el clientelismo para contener la crisis política que el país vivía. Es de anotar que Leal y Dávila se nutren del trabajo de Fernando Guillén Martínez, quien definió la estructura social

Como el conjunto sistemático de normas, expectativas y actitudes que condicionan las relaciones humanas -por esto- es fácil ver que ellas se originan como instituciones formales o informales, en el seno de las asociaciones predominantes. Estas asociaciones, resultado de innumerables factores, entre los cuales tienen capital importancia las relaciones de producción y la composición histórica y demográfica, proyectan su sistema de "status roles" sobre el conjunto de la sociedad en la cual se insertan y la tiñen de su propia tonalidad específica. Al final, la estructura social, en su conjunto (simbología, sistema de roles, status, y valores) no es otra cosa que una ampliación de la estructura de las asociaciones dominantes. ${ }^{44}$

\footnotetext{
${ }^{43}$ Ver Leal Buitrago y Dávila Ladrón de Guevara, Clientelismo, 48.

${ }^{44}$ Ver Guillén Martínez, El poder politico en Colombia, xi y ss.
} 
El alcance del poder político está condicionado por el lugar que los actores ocupan en dicha estructura de poder. Los partidos políticos, de esta forma, se consolidan como una red de relaciones de dependencia jerárquica, cuyo objetivo es la cooptación de presupuesto público para el mantenimiento de una exclusiva clientela patronal. ${ }^{45}$ En este orden, el clientelismo adquiere un papel fundamental en el mantenimiento del orden sociopolítico del sistema. ${ }^{46}$

Los autores que se inscriben en el estructural-funcionalismo prefieren el término de sistema político y no el de régimen. $\mathrm{Al}$ respecto, Javier Torres señala que "[...] la respuesta es que los sistemas políticos dan cuenta del verdadero funcionamiento de lo político en una sociedad, es decir, de las reglas informales que hacen parte del ejercicio político. Mientras que el concepto de régimen político se limita a la normatividad, a las reglas formales que arbitran el funcionamiento de la política". ${ }^{47}$

Es decir, el régimen es resultado de unas dinámicas que los sujetos, inmersos en una estructura social de roles, le imprimen, dándole un carácter propio que solo puede ser observado a partir del funcionamiento del sistema en general. La principal limitación de este enfoque es que tiende más que a explicar, a justificar las relaciones de la sociedad. No en vano, son los autores que se emparentan con este enfoque los que iniciaron la tendencia de atribuir funciones positivas al clientelismo.

\footnotetext{
${ }^{45}$ Comparar Jaramillo, Clientelismo y poder: relectura, 12.

${ }^{46}$ Comparar Martz, The Politics, 8.

${ }^{47}$ Ver Javier Fernando Torres Preciado, "Vicio y virtud : el sistema político colombiano en el periodo 1848-1885” (tesis de maestría, Universidad de los Andes, Bogotá, 2008), 12.
} 


\subsection{Enfoque neo-institucionalista}

Los preceptos del nuevo institucionalismo emergieron durante las décadas de los setenta y ochenta en contraposición a los enfoques conductista, de elección racional y funcionalista. Sin embargo, y muy paradójicamente, el enfoque representa una reformulación teórica que mantiene algunos postulados del viejo institucionalismo, del conductismo, de la elección racional y de la psicología cognitiva ${ }^{48}$ Por lo anterior, se ha generado un amplio debate entre los autores y diferentes versiones del neoinstitucionalismo, lo que ha generado dificultad en la identificación de las tendencias teóricas de los estudios sobre clientelismo que han sido producidos en Colombia. Dentro de esta clasificación, fueron incluidos todos los estudios que dieron prioridad a las instituciones, siendo estas formales o informales, o que hicieron uso de enfoques enmarcados dentro de la elección racional.

A diferencia del funcionalismo y del conductismo, el nuevo institucionalismo concibe la historia como un proceso complicado que no necesariamente conduce a formas más elevadas de organización política. ${ }^{49}$ Es decir, la nueva perspectiva rompe con la idea de progreso lineal. En segundo lugar, a diferencia de la elección racional, establece que los actores políticos reflejan los valores de las instituciones a las que están vinculados y, por tanto, su accionar no responde solamente a la maximización del beneficio

${ }^{48}$ Comparar Rodrigo Losada Lora y Andrés Casas Casas, Enfoques para el análisis politico: historia, epistemología y perspectivas de la ciencia politica (Bogotá: Editorial Pontificia Universidad Javeriana, 2010), 178.

${ }^{49}$ Ibid., 179. 
personal; $;^{50}$ así como también se rompe con los reduccionismos de atribuir accionares colectivos a comportamientos individuales. ${ }^{51}$

El viejo institucionalismo del siglo xIX consideraba a las instituciones sociales como "los núcleos básicos de la organización social, comunes a todas las sociedades y encargadas de algunos de los problemas fundamentales de toda vida social ordenada" ${ }^{52}$ La nueva perspectiva teórica, en un esfuerzo por estudiar las dinámicas al interior de las instituciones, tanto formales como informales, y los intereses en juegos, tanto de individuos como de grupos, no solo parte del rol fundamental de las instituciones, sino que agrega tres elementos más: en primer lugar, integra conceptos y preceptos económicos a las viejas perspectivas centradas en las instituciones; como producto de lo anterior, trasciende las teorías tradicionales concediéndole un rol importante tanto a las instituciones como a los actores sociales e individuales y a su comportamiento racional; y finalmente, supone que el orden es el resultado del cumplimiento de las normas anteriormente establecidas, por lo que un cambio solo puede ser dado de forma paulatina e incremental. ${ }^{53}$

Los estudios sobre clientelismo en Colombia han estado muy influenciados por algunos preceptos del viejo institucionalismo pero, sobre todo, se nutren de presupuestos que reformularon la perspectiva sobre las instituciones sociales.

En la década del ochenta, desde el neoinstitucionalismo se empezó a estudiar el clientelismo político en Colombia. Rodrigo

\footnotetext{
${ }^{50}$ Comparar Federico Rivera Romero, "El neoinstitucionalismo y la investigación en las ciencias sociales", Revista Centroamericana de Administración Pública-ICAP, (2013):101-128.

${ }^{51}$ Comparar Losada Lora y Casas Casas, Enfoques, 178.

${ }^{52}$ Ver Sills y otros, Enciclopedia, vol. I, 299.

${ }^{53}$ Comparar Rivera Romero, "El neoinstitucionalismo”, 102.
} 
Losada investigó el comportamiento electoral desde el paradigma de la elección racional. ${ }^{54}$ Años más tarde, se identificaron trabajos que abordaron el clientelismo desde la perspectiva del interés individual, a partir de teorías de juegos. ${ }^{55}$ En la década del noventa se vivió el auge de los estudios centrados en las instituciones. Desde un mismo paradigma, se generaron aproximaciones que parten del mismo principio, pero dan soluciones diametralmente opuestas al fenómeno. Por un lado, están los estudios que definen al clientelismo como la principal institución informal que distorsiona el funcionamiento de las instituciones formales tales como la democracia y el Estado social de derecho. El trabajo de Mauricio García y Javier Revelo se inscribe en esta corriente afirmando que:

\begin{abstract}
Existe una relación inversa entre clientelismo y la ley: a mayor importancia de aquel en la determinación de los comportamientos ciudadanos y de los funcionarios públicos, menor el peso de esta y viceversa. Por eso el clientelismo está en contravía del Estado de Derecho, y por eso mismo la mayor importancia de las relaciones clientelistas entraña un aumento de la debilidad institucional. ${ }^{56}$
\end{abstract}

${ }^{54}$ Comparar Losada Lora, Clientelismo.

${ }^{55}$ Comparar Jorge Andrés Gallego Durán y Rafael Raciborsky, Clientelism, Income, Inequality, and Social Preferences: An Evolutionary Approach to Poverty Traps, consultado agosto 29,2014,http://growth-institutions.ec.unipi.it/pages/InstitutionI/clientelism.pdf)); Rafael José Santos Villagrán, “Bogotá:The Collapse of a Political Machine”(cuadernillo no publicado Universidad de los Andes, Facultad de Economía, Bogotá, 2007).

${ }^{56}$ Ver Mauricio García Villegas y Javier Eduardo Revelo Rebolledo. Estado alterado. Clientelismo, mafias y debilidad institucional en Colombia (Bogotá: Centro de estudios de Derecho, Justicia y Sociedad), 23. 
Por otro lado, están los estudios que indican que la institución informal del clientelismo se ha trasformado a partir de cambios en el régimen legal. Desde esta perspectiva, el clientelismo es una institución que carece de los formalismos y de la fuerza legal de las relaciones contractuales, siendo una relación semi-ilegal que, aunque no viola las leyes, sí va en contra de los principios éticos. ${ }^{57}$ Se trata de un pacto social que está determinado por valores tales como la lealtad. Es, sin duda, una institución que se entrelaza con las instituciones formales, dando como resultado procesos diferentes a los establecidos dentro de las normas formales. Estudios representativos de este enfoque son, por ejemplo, el de Francisco Gutiérrez y Andrés Dávila. Sus trabajos sostienen que a partir de 1991, la estructura piramidal del clientelismo moderno se trasformó en uno de mercado, que da cabida a dinámicas de participación y representación política, visión que imprime una postura más comprensiva del fenómeno. ${ }^{58}$

Introduce así el neoinstitucionalismo visiones contradictorias del clientelismo, negativas o pragmáticamente positivas. Cuando los estudios enmarcados en esta corriente descargan toda responsabilidad en instituciones como el Estado y el gobierno, se dice que se exime de su papel proactivo a actores individuales y colectivos de la sociedad civil. Adicionalmente, los estudios con modelos económicos del fenómeno terminan por generar reduccionismos del fenómeno.

${ }^{57}$ Comparar Duarte, Educación, 8.

${ }^{58}$ Comparar Dávila Ladrón de Guevara y Delgado Varela, La metamorfosis Francisco Gutiérrez Sanín, "Clientelismo y sus enredos”. 


\subsection{Enfoque socio-antropológico}

Para José González hasta la década del noventa los estudios sobre clientelismo se inscribían en dos grandes lineamientos teóricos: i) la teoría liberal, más cercana a la derecha política, y ii) la marxista, proclive a la izquierda. González observa que en el marco de una sociedad con aspiraciones igualitarias, principios universalistas y sistemas democráticos de avanzada, la humanidad se enfrenta con el problema de la persistencia del homo bierarchicus sobre el bomo aequalis. En este contexto, desde la derecha, el clientelismo es asumido como un fenómeno "natural", dado su visión jerarquizada y patriarcal del mundo. No cuestionar esta postura condena a la humanidad a una vida de clientelismo y le resta su carácter dinámico y socio-histórico. La izquierda, por su parte, combate al clientelismo a toda costa para lograr la igualdad plena. No obstante, sus regímenes políticos no han logrado tal igualdad, ni han superado prácticas clientelistas. ${ }^{59}$

Para González, ninguna de estas aproximaciones permitió repensar conceptualmente al clientelismo, ni replantear sus prácticas. Por tanto, propone observarlo como un fenómeno propio del mundo actual, que se evidencia por el choque entre patrones culturales y tipos ideales. No es, entonces, producto de relaciones feudales o arcaicas, sino más bien de una tensión, que sólo es posible resolver a partir de la superación de las visiones moralistas. Además, anota que el clientelismo social y político constituye un universo antropológico. ${ }^{60}$

Los planteamientos de González Alcantud sintetizan el enfoque socio-antropológico. En términos generales, Rodrigo Losada

\footnotetext{
${ }^{59}$ Comparar José A. González Alcantud, El clientelismo politico. Perspectiva socioantropológica (Barcelona: Anthropos Editorial, 1997).

${ }^{60}$ Ibid., 21.
} 
y Andrés Casas, quienes lo denominan enfoque histórico-sociológico, lo refieren como una visión que da prioridad al estudio del entorno social y cultural. Así mismo, los datos son construidos a partir de fenómenos observables empíricamente, en donde se parte de la posibilidad de identificar tendencias constantes en la política y devenir de los pueblos y sociedades; por lo mismo, la historia se convierte en el principal instrumento para comprensión de los fenómenos. Tal como se muestra, su interés recae más que en individuos, en grandes colectividades humanas como la sociedad, los pueblos, las culturas, el Estado, etc. ${ }^{61}$

Aterrizando los preceptos del enfoque socio-antropológico al campo del clientelismo político, se identifica que los planteamientos de González Alcantud se configuraron como el primer referente de los estudios de este corte durante el presente siglo en Colombia. Estos se caracterizaron por tomar distancia de la visión moralista y por adoptar dimensiones ancladas a la cultura política, donde se hizo referencia a dinámicas sociales como la creación de ciudadanía, la participación y la representación política, todas dinámicas observables al anterior del mismo fenómeno clientelista. Así mismo, el clientelismo es tomado como algo más allá de un simple fenómeno atávico. ${ }^{62}$ En este contexto, es de citar el trabajo de Rocío Rubio, quien estudió la red clientelista del político

${ }^{61}$ Comparar Losada Lora y Casas Casas, Enfoques, 148.

${ }^{62}$ Dentro de las obras que abordan la problemática desde esta perspectiva son de relatar: Miguel García Sánchez, ¿Ciudadanía avergonzada? Democracia local y construcción de ciudadanía en Bogotá (Bogotá: Universidad de los Andes y Universidad Nacional de Colombia, 2003); Miguel García Sánchez, "La política bogotana, un espacio de recomposición (1982-2001)”, en Degradación o cambio: evolución del sistema político colombiano, compilado por Francisco Gutiérrez Sanín (Bogotá: Editorial Norma, 2002); Escalante, "Clientelismo", 31-41. 
conservador Telésforo Pedraza y la definió como una forma de hacer política. La autora anota que su tesis sobre el clientelismo

[...] marca una distancia frente a aquellos que lo narran como un fenómeno atávico, pre moderno o como un rezago de las formas arcaicas del quehacer político, así como frente a aquellos que lo observan como un mecanismo articulador entre las formas pre modernas de lo político y las modernas. Tal distancia no implica observar el clientelismo como un fenómeno absolutamente moderno que subordina elementos pre-modernos. Se esgrime la hipótesis según la cual este fenómeno se apoya en tales elementos. Son estos finos hilos a través de los cuales se teje la trama de las redes clientelares y, en el caso del teleforismo, relatan una racionalidad particular y la aplicación de un principio de economía para su producción eficiente. Se trata, entonces, de interrogar hasta dónde se han modificado los mecanismos de producción y reproducción de la red teleforista, a quien sirven y en qué contextos [...] también se toma distancia de las tesis que observan el carácter universal del clientelismo. Por otra parte, se tienden puentes a las miradas políticas del fenómeno en el país. Algunas han justificado de cierto modo su existencia, expresando que es un fenómeno universal asociado a condiciones de desigualdad socioeconómica, mientras que otras lo han señalado como la mayor patología del sistema político. El texto invita a superar las anteriores versiones. En el primer caso, porque no permite anotar particularidades del fenómeno, y pareciera que mientras no se superen las desigualdades, el clientelismo será consustancial al 
quehacer político. En el segundo, porque tras las tensiones de políticos "clientelistas" versus "no clientelistas", "presentables" versus "representables", "independientes" versus "tradicionales", "sanos" versus "corruptos", se esconden densas relaciones entre unos y otros, y se negocian apoyos; y, por último, porque ninguna de las dos categorías puede ser tomada a priori como condición de moralidad pública. ${ }^{63}$

En síntesis, la transformación de los paradigmas ha conducido a replantear las formas de aproximación al clientelismo: se presentó un desplazamiento de las ideas sobre desarrollo y capitalismo hacia un análisis de clase y el estudio de las instituciones formales. Actualmente, el clientelismo es asumido como un universo complejo, que puede sufrir trasformaciones a partir de las reformas al régimen. Las nuevas aproximaciones se caracterizan por posturas más comprensivas del fenómeno, donde la dimensión de la cultura y el comportamiento político adquieren un papel fundamental en los análisis. A manera de conclusión de este acápite, se presentan a continuación cinco tablas que sintetizan los principales rasgos de cada uno de los enfoques identificados en este trabajo.

${ }^{63}$ Ver Rubio Serrano, No bay paraísos, 15-16. 
Tabla 1. Rasgos del enfoque funcionalista en el clientelismo político

\begin{tabular}{|c|c|c|c|}
\hline \multirow{2}{*}{$\begin{array}{l}\text { Enfoque o } \\
\text { paradigma }\end{array}$} & \multicolumn{2}{|c|}{ Características } & \multirow[b]{2}{*}{ Críticas al enfoque } \\
\hline & Generales & $\begin{array}{l}\text { Aplicadas al estudio } \\
\text { del clientelismo }\end{array}$ & \\
\hline Funcionalista & $\begin{array}{l}\text { La sociedad fue } \\
\text { entendida como } \\
\text { un organismo } \\
\text { compuesto por } \\
\text { partes que tendían } \\
\text { a adaptarse a las } \\
\text { condiciones del } \\
\text { ambiente. } \\
\text { La adaptación de } \\
\text { los subsistemas a } \\
\text { las condiciones del } \\
\text { ambiente definía } \\
\text { la funcionalidad o } \\
\text { disfuncionalidad } \\
\text { de los mismos. }\end{array}$ & $\begin{array}{l}\text { Las sociedades } \\
\text { rurales o sociedades } \\
\text { consideradas } \\
\text { "arcaicas" fueron } \\
\text { preferentemente } \\
\text { tomadas como las } \\
\text { unidades de análisis } \\
\text { y el microanálisis fue } \\
\text { la metodología más } \\
\text { empleada. } \\
\text { La relación clientelar } \\
\text { es asumida como un } \\
\text { contrato personal, } \\
\text { de libre asociación } \\
\text { e informal entre } \\
\text { dos individuos, con } \\
\text { diferente estatus } \\
\text { pero con una } \\
\text { contraprestación } \\
\text { recíproca. } \\
\text { Estos primeros } \\
\text { estudios establecieron } \\
\text { las características } \\
\text { base del clientelismo: } \\
\text { el carácter diádico y } \\
\text { la relación cara a cara. } \\
\text { Establece relaciones } \\
\text { en tres direcciones: i) } \\
\text { la relación patrón- } \\
\text { cliente (P-C); ii) la } \\
\text { relación patrón- } \\
\text { patrón (P-P); iii) } \\
\text { la relación cliente- } \\
\text { patrón (c-P). }\end{array}$ & $\begin{array}{l}\text { El clientelismo fue } \\
\text { asociado con una forma } \\
\text { de subdesarrollo. El } \\
\text { fenómeno estaba dado } \\
\text { a desaparecer con la } \\
\text { llegada de la modernidad. } \\
\text { Se introdujo el concepto } \\
\text { de bróker o intermediario } \\
\text { y el estudio de redes y } \\
\text { triadas. }\end{array}$ \\
\hline
\end{tabular}

Fuente: Tabla elaborada por el autor con base en la información presente en las fichas bibliográficas elaboradas. 
Tabla 2. Rasgos del enfoque marxista en el clientelismo político

\begin{tabular}{|c|c|c|c|}
\hline \multirow{2}{*}{$\begin{array}{l}\text { Enfoque o } \\
\text { paradigma }\end{array}$} & \multicolumn{2}{|c|}{ Características } & \multirow[b]{2}{*}{ Críticas al enfoque } \\
\hline & Generales & $\begin{array}{c}\text { Aplicadas al estudio del } \\
\text { clientelismo }\end{array}$ & \\
\hline \multirow{3}{*}{ Marxista } & $\begin{array}{l}\text { Las relaciones } \\
\text { de producción } \\
\text { constituyen la base } \\
\text { de la estructura } \\
\text { económica y por ende } \\
\text { la base de la sociedad. } \\
\text { (Losada, Rodrigo, } \\
\text { 2010, p. 263) }\end{array}$ & $\begin{array}{l}\text { Imprime a los estudios } \\
\text { de clientelismo el análisis } \\
\text { histórico y de clase. }\end{array}$ & $\begin{array}{l}\text { El clientelismo } \\
\text { manifestó ser un } \\
\text { fenómeno que podía } \\
\text { darse entre clases, } \\
\text { pero también en } \\
\text { todas direcciones, } \\
\text { restando alcance } \\
\text { y capacidad } \\
\text { explicativa al } \\
\text { enfoque marxista. }\end{array}$ \\
\hline & $\begin{array}{l}\text { Las condiciones } \\
\text { materiales están } \\
\text { determinadas } \\
\text { por los modos } \\
\text { de producción, } \\
\text { la propiedad y la } \\
\text { tenencia de la tierra. }\end{array}$ & $\begin{array}{l}\text { El clientelismo fue } \\
\text { definido en términos de } \\
\text { instrumentalización de } \\
\text { una clase, dueña de los } \\
\text { medios de producción } \\
\text { político-económicos, } \\
\text { sobre otra desprotegida a } \\
\text { la que se le saca el mayor } \\
\text { beneficio. }\end{array}$ & $\begin{array}{l}\text { La referencia a las } \\
\text { grandes estructuras } \\
\text { de poder, partidos, } \\
\text { élites o clases generó } \\
\text { dificultades para } \\
\text { operacionalizar } \\
\text { y estudiar el } \\
\text { fenómeno. }\end{array}$ \\
\hline & $\begin{array}{l}\text { Existe una relación } \\
\text { de dominación de } \\
\text { unas clases sobre } \\
\text { otras. }\end{array}$ & $\begin{array}{l}\text { Introdujo el } \\
\text { macroanálisis: la relación } \\
\text { de dominación entre } \\
\text { sociedades pequeñas y los } \\
\text { centros de poder. }\end{array}$ & $\begin{array}{l}\text { La referencia al } \\
\text { sector rural como } \\
\text { premoderno y } \\
\text { precapitalista restó } \\
\text { vigencia y capacidad } \\
\text { explicativa a las } \\
\text { relaciones actuales } \\
\text { del campesinado y al } \\
\text { agro colombiano. }\end{array}$ \\
\hline
\end{tabular}

Fuente: Tabla elaborada por el autor del presente trabajo con base en la información presente en las fichas bibliográficas elaboradas. 
Tabla 3. Rasgos del enfoque estructural-funcionalista en el clientelismo político

\begin{tabular}{|c|c|c|c|}
\hline \multirow[b]{2}{*}{$\begin{array}{l}\text { Enfoque o } \\
\text { Paradigma }\end{array}$} & \multicolumn{2}{|c|}{ Características } & \multirow[b]{2}{*}{ Críticas al enfoque } \\
\hline & Generales & $\begin{array}{l}\text { Aplicadas al } \\
\text { estudio del } \\
\text { clientelismo }\end{array}$ & \\
\hline $\begin{array}{l}\text { Estructural- } \\
\text { funcionalista }\end{array}$ & $\begin{array}{l}\text { Integra preceptos } \\
\text { básicos de los } \\
\text { enfoques: funcionalista, } \\
\text { estructuralista y } \\
\text { sistémico. } \\
\text { Entiende la estructura } \\
\text { social como el conjunto } \\
\text { sistemático de normas, } \\
\text { expectativas y actitudes } \\
\text { que condicionan } \\
\text { las relaciones } \\
\text { humanas, originando } \\
\text { instituciones formales } \\
\text { o informales en el seno } \\
\text { de las asociaciones } \\
\text { predominantes. } \\
\text { Explica el } \\
\text { funcionamiento interno } \\
\text { de la unidad en su } \\
\text { relación con su entorno } \\
\text { inmediato. } \\
\text { Aplica conceptos de la } \\
\text { biología a las ciencias } \\
\text { sociales. Los conceptos } \\
\text { fundamentales son los de } \\
\text { estructura social, sistema, } \\
\text { función, rol, estatus y } \\
\text { proceso. }\end{array}$ & $\begin{array}{l}\text { El clientelismo } \\
\text { adquiere un papel } \\
\text { fundamental en el } \\
\text { mantenimiento del } \\
\text { orden sociopolítico } \\
\text { del sistema. } \\
\text { Acude a la } \\
\text { diferenciación de } \\
\text { los conceptos de } \\
\text { régimen político } \\
\text { y del sistema } \\
\text { político, matizando } \\
\text { las dinámicas de } \\
\text { las instituciones } \\
\text { informales y de las } \\
\text { formales. } \\
\text { Articula el } \\
\text { microanálisis con el } \\
\text { macroanálisis. }\end{array}$ & $\begin{array}{l}\text { La principal } \\
\text { limitación de este } \\
\text { enfoque es que } \\
\text { tiende, más que a } \\
\text { explicar, a justificar } \\
\text { las relaciones de la } \\
\text { sociedad. }\end{array}$ \\
\hline
\end{tabular}

Fuente: tabla elaborada por el autor del prsente trabajo con base en lainformación presente en las fichas bibliográficas elaboradas. 
Tabla 4. Rasgos del enfoque institucionalista en el clientelismo político

\begin{tabular}{|c|c|c|c|}
\hline \multirow{2}{*}{$\begin{array}{l}\text { Enfoque o } \\
\text { paradigma }\end{array}$} & \multicolumn{2}{|c|}{ Características } & \multirow[b]{2}{*}{ Críticas al enfoque } \\
\hline & Generales & $\begin{array}{l}\text { Aplicadas al estudio del } \\
\text { clientelismo }\end{array}$ & \\
\hline \multirow{6}{*}{ 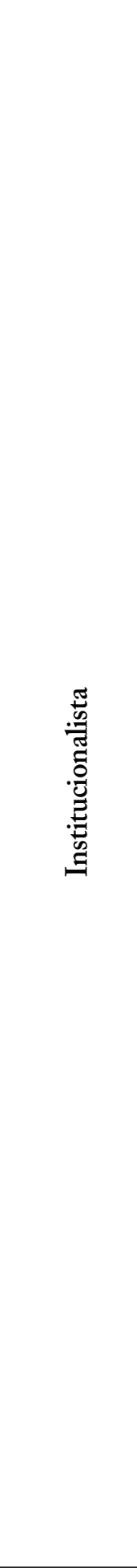 } & $\begin{array}{l}\text { Analiza las } \\
\text { instituciones, los actores } \\
\text { y su comportamiento } \\
\text { racional. }\end{array}$ & $\begin{array}{l}\text { Analiza el clientelismo en } \\
\text { relación con instituciones } \\
\text { formales como: el Estado, } \\
\text { la democracia, el sistema } \\
\text { político. }\end{array}$ & $\begin{array}{l}\text { Cuando se descarga } \\
\text { toda responsabilidad en } \\
\text { instituciones como el } \\
\text { Estado y el gobierno, se } \\
\text { dice que se exime de su } \\
\text { papel proactivo a actores } \\
\text { individuales y colectivos } \\
\text { de la sociedad civil. }\end{array}$ \\
\hline & $\begin{array}{l}\text { Da un papel } \\
\text { protagónico e } \\
\text { independiente a } \\
\text { las instituciones } \\
\text { sin desconocer la } \\
\text { importancia de los } \\
\text { actores individuales, } \\
\text { incluyendo en estos los } \\
\text { procesos sociopolíticos y } \\
\text { participativos. }\end{array}$ & $\begin{array}{l}\text { Algunos autores inscritos } \\
\text { en esta perspectiva teórica } \\
\text { definen el clientelismo como } \\
\text { una relación semi-ilegal que, } \\
\text { aunque no viola las leyes, sí } \\
\text { va en contra de los principios } \\
\text { éticos; }\end{array}$ & $\begin{array}{l}\text { Algunos enfoques } \\
\text { económicos aplicados } \\
\text { al comportamiento } \\
\text { electoral se presentan } \\
\text { como visiones simplistas } \\
\text { y reduccionistas del } \\
\text { fenómeno. }\end{array}$ \\
\hline & $\begin{array}{l}\text { Integra conceptos y } \\
\text { preceptos económicos } \\
\text { a las viejas perspectivas } \\
\text { teóricas centradas en las } \\
\text { instituciones. }\end{array}$ & $\begin{array}{l}\text { como un pacto social que } \\
\text { está determinado por valores } \\
\text { tales como la lealtad; }\end{array}$ & $\begin{array}{l}\text { Algunos trabajos } \\
\text { enmarcados en el enfoque } \\
\text { de elección racional } \\
\text { han presentado fallas } \\
\text { metodológicas. }\end{array}$ \\
\hline & $\begin{array}{l}\text { El orden es el resultado } \\
\text { del cumplimiento de las } \\
\text { normas anteriormente } \\
\text { establecidas, por lo que } \\
\text { un cambio solo puede } \\
\text { ser dado de forma } \\
\text { paulatina e incremental. }\end{array}$ & $\begin{array}{l}\text { como una institución } \\
\text { informal que influye a las } \\
\text { instituciones formales. } \\
\text { Esta influencia puede ser } \\
\text { asumida como un aspecto } \\
\text { problemático o desde una } \\
\text { perspectiva comprensiva. }\end{array}$ & $\begin{array}{l}\text { Las reformas legales e } \\
\text { institucionales antes que } \\
\text { producir una erradicación } \\
\text { de un fenómeno visto } \\
\text { como algo netamente } \\
\text { negativo, ha producido la } \\
\text { mutación, complejización y } \\
\text { transformación del mismo. }\end{array}$ \\
\hline & $\begin{array}{l}\text { Rompe con la idea de } \\
\text { progreso lineal. }\end{array}$ & $\begin{array}{l}\text { Algunos estudios han } \\
\text { aplicado modelos } \\
\text { económicos para la } \\
\text { comprensión del fenómeno } \\
\text { del clientelismo a lo largo del } \\
\text { proceso electoral. }\end{array}$ & \\
\hline & $\begin{array}{l}\text { Da mayor importancia a } \\
\text { los procesos sociales que } \\
\text { a los resultados de los } \\
\text { mismos. }\end{array}$ & $\begin{array}{l}\text { Estudian el fenómeno } \\
\text { para poder producir } \\
\text { modificaciones en el mismo, } \\
\text { bien sea a partir de ingeniería } \\
\text { institucional o a partir de } \\
\text { otras medidas. }\end{array}$ & \\
\hline
\end{tabular}

Fuente: Tabla elaborada por el autor del presente trabajo con base en la información presente en las fichas bibliográficas elaboradas. 
Tabla 5. Rasgos del enfoque socio-antropológico en el clientelismo político

\begin{tabular}{|c|c|c|c|}
\hline \multirow{2}{*}{$\begin{array}{l}\text { Enfoque o } \\
\text { paradigma }\end{array}$} & \multicolumn{2}{|c|}{ Características } & \multirow[b]{2}{*}{ Críticas al enfoque } \\
\hline & Generales & $\begin{array}{l}\text { Aplicadas al estudio } \\
\text { del clientelismo }\end{array}$ & \\
\hline $\begin{array}{l}\text { Socio- } \\
\text { antropológico }\end{array}$ & $\begin{array}{l}\text { Enfoque centrado } \\
\text { en el entorno social y } \\
\text { cultural. } \\
\text { Su argumentación } \\
\text { está basada en } \\
\text { hechos observables. } \\
\text { Busca identificar } \\
\text { tendencias } \\
\text { constantes en la } \\
\text { política de los } \\
\text { pueblos. } \\
\text { La historia de los } \\
\text { pueblos da una } \\
\text { comprensión de los } \\
\text { fenómenos. }\end{array}$ & $\begin{array}{l}\text { El clientelismo } \\
\text { social y político } \\
\text { constituye un universo } \\
\text { antropológico. } \\
\text { Se evidencia por el } \\
\text { choque entre patrones } \\
\text { culturales y tipos } \\
\text { ideales. } \\
\text { El clientelismo como } \\
\text { un fenómeno propio } \\
\text { de la modernidad, no } \\
\text { como un fenómeno } \\
\text { atávico. } \\
\text { Se distancia de una } \\
\text { visión moralista y } \\
\text { contempla la presencia } \\
\text { de dimensiones } \\
\text { tales como la cultura } \\
\text { política, la creación } \\
\text { de ciudadanía, la } \\
\text { participación y la } \\
\text { representación política } \\
\text { en este fenómeno. }\end{array}$ & $\begin{array}{l}\text { Es exitoso cuando } \\
\text { se trata de describir } \\
\text { procesos, pero fracasa } \\
\text { a la hora de explicar } \\
\text { los mismos. } \\
\text { La comprensión del } \\
\text { fenómeno puede } \\
\text { recurrir en una } \\
\text { justificación del } \\
\text { mismo. }\end{array}$ \\
\hline
\end{tabular}

Fuente: Tabla elaborada por el autor del presente trabajo con base en la información presente en las fichas bibliográficas elaboradas. 


\section{Tipologías de clientelismo}

Si bien la literatura señala que el fenómeno del clientelismo ha sido observado desde el siglo xix en Colombia, no siempre se hace referencia al mismo tipo de fenómeno. De hecho, las transformaciones en las condiciones económicas, sociales y de los regímenes políticos ha generado consenso entre los mismos autores al identificar tres tipos de clientelismo. Por ejemplo, durante el siglo xix, los recursos base del intercambio clientelista eran tanto públicos como privados debido a la débil capacidad fiscal del Estado de la época. ${ }^{64}$ Durante el siglo xx, en cambio, el aumento de la capacidad de recaudo estatal hizo que las clientelas empezaran a ser sostenidas exclusivamente con recursos públicos. No obstante, en los años ochenta se observó que los recursos públicos no alcanzaban a cubrir la totalidad de las demandas de las redes clientelistas y se le abrió la puerta a capitales privados (no del todo lícitos) en las dinámicas políticas.

Estos cambios en la naturaleza del intercambio de las relaciones clientelistas permiten plantear tres tipos de clientelismo: ${ }^{65}$ el tradicional, que se presentó a lo largo del siglo XIx y parte del xx; el moderno, que estuvo presente a lo largo de la segunda mitad del siglo xx; y el de mercado, estudiado especialmente para el caso de Bogotá post Constitución de 1991. A continuación se presenta cada tipología y los debates teóricos que las acompañaron.

\footnotetext{
${ }^{64}$ Comparar Torres Preciado, "Vicio", 18.

${ }^{65}$ Estas tres categorías ad hoc fueron formuladas por los diferentes autores. Se observa que existe consenso alrededor de las mismas.
} 


\subsection{Clientelismo tradicional}

El clientelismo tradicional fue estudiado a partir de los trabajos sobre caciquismo y patronazgo de autores tales como Malcolm Deas y Fernando Guillén Martínez. El estudio de este tipo de clientelismo partió de la revisión de las instituciones coloniales. $\mathrm{Al}$ respecto, Guillén Martínez encuentra que el caudillismo y el clientelismo son formas de asociación política con génesis en la encomienda. Esta figura generó lealtades feudales a partir de pactos tácitos sobre el intercambio de prestaciones y contraprestaciones, y es antecedente de la hacienda, figura que logró proyectarse hasta mediados del siglo xx y se caracterizó por presentar un intercambio casi exclusivo entre el patrón, gamonal o cacique y el cliente, siervo o campesino. Se trataba de una relación diádica, personal y directa, donde los recursos comprometidos provenían del acervo patrimonial y privado del patrón. En el clientelismo de corte tradicional, el Estado no ocupaba un papel central en la relación y en el sistema de adhesiones y lealtades. ${ }^{66}$

Desde una postura institucionalista, se señaló que las formas de asociación del siglo XIX superaron el espacio temporal de la encomienda de tal manera que se trasladaron al espacio temporal de la hacienda. Lo anterior es la razón por la cual los hacendados fueron los mismos que conformaron los dos partidos políticos tradicionales. Se sigue la senda del pasado de manera que las élites políticas regionales lograron mantenerse en el juego por el control del Estado. El traslado del modelo de la hacienda al Estado implicó, a su vez, el tránsito de un tipo de dominación patrimonial a uno de dominación burocrática. El Estado se convirtió en el patrón de los patrones y estos, a su vez, pasaron a ser meros intermediarios. Con ello se efectuó un desplazamiento hacia un

${ }^{66}$ Comparar Dávila Ladrón de Guevara, “Clientelismo, intermediación”, 65-66. 
tipo diferente de clientelismo. En este, los políticos, la burocracia y el Estado empiezan a ser los protagonistas. Se trata, entonces, de un clientelismo moderno, burocrático o estatal. Este tránsito del clientelismo tradicional al moderno se dio durante el Frente Nacional. Sin embargo, algunas características del régimen (tales como su aspecto cerrado, excluyente y oligárquico) tienen sus orígenes en estas primeras formas de asociación, las cuales pese a las rupturas presentan continuidades hasta el presente.

\subsection{Clientelismo moderno}

El clientelismo moderno es la tipología con mayor frecuencia abordada por los autores que trabajan la temática. Este hace referencia al fenómeno que alcanzó grandes proporciones dentro del sistema político colombiano; es decir, a aquel contra el cual Carlos Lleras Restrepo emprendió su lucha cuando publicó, en el diario Nueva Frontera, un artículo titulado "Las elecciones sucias y otras $\operatorname{cosas}{ }^{767}$ que, posteriormente, trató de ser erradicado vía reformas constitucionales.

El montaje del clientelismo moderno se surtió a lo largo del Frente Nacional y tuvo su punto máximo de concreción a partir de la reforma de 1968. ¿Qué generó el paso de un tipo de clientelismo a otro? Eduardo Díaz explica que a raíz del modelo cepalino de sustitución de importaciones, implementado desde mediados del siglo $\mathrm{xx}$, se "[...] liberó a amplios sectores de las relaciones de servidumbre $[. .$.$] de los gamonales y jefaturas políticas tradicionales,$ ubicándolos en las barricadas y cinturones de miseria de las grandes ciudades o centros industriales". ${ }^{68}$

\footnotetext{
${ }^{67}$ Ver Leal Buitrago y Davila Ladrón de Guevara, Clientelismo, 35.

${ }^{68}$ Ver Jaramillo, Clientelismo y poder: relectura, 18.
} 
El cambio de una producción agrícola a una industrial implicó: una mayor urbanización, relaciones económicas monetizadas, diversificación de clases sociales, expansión de las instituciones del Estado, entre otros. ${ }^{69}$ Esto generó una ruptura con las formas tradicionales de organización política en la medida que las relaciones de servidumbre se transformaron en relaciones laborales y las lealtades fueron sustituidas por otros mecanismos de vinculación. Los más afectados fueron los partidos tradicionales, quienes tuvieron que desarrollar mecanismos para defender y solidificar su autoridad en la nueva forma de poder estatal. ${ }^{70} \mathrm{De}$ hecho, el Frente Nacional puede interpretarse como el esfuerzo de tales partidos por mantener su poder, siendo los intermediarios entre la población rural (y algún porcentaje de la urbana) y el Estado, presentándose como únicos proveedores de servicios y bienes públicos.

Cristina Escobar señala, al respecto, que la relación clientelista se caracterizó por ser "[...] periódica, específica, causal, instrumental, y el voto es [fue] el principal bien de intercambio. Por estos motivos, el clientelismo de intermediación debe ser entendido en relación con el Estado, sus instituciones burocráticas, regímenes políticos, estructuras y sistemas de partidos y asociaciones civiles". ${ }^{71}$

El nuevo líder, señala Roll, ya no es el típico terrateniente o comerciante próspero. Ahora, es un individuo que, por lo general, proviene de sectores populares y ha escalado en la maquinaria

${ }^{69}$ Ibid., 25.

${ }^{70}$ Comparar Martz, The Politics, 31.

${ }^{71}$ Ver Cristina Escobar, Clientelism Movilization and Citizenship: Peasant Politics in Sucre, Colombia (Michigan: UMI, Ann Arbor, 1998), 9. 
política. Se trata de un intermediario: es cliente frente al poder central, pero patrón frente a las instancias regionales. ${ }^{72}$

Jorge Valenzuela, en un estudio de caso sobre la producción arrocera en el Huila en $1978,{ }^{73}$ encuentra que el perfil del líder en el nivel local varía del departamental. En el primer nivel, el líder es más cercano a un clientelismo tradicional, mientras que en el segundo a uno de corte moderno.

En este orden, las categorías de clientelismo tradicional y moderno no necesariamente obedecen a categorías temporales. También pueden obedecer a lógicas espaciales de organización del poder político. ${ }^{74}$ En síntesis, el recorrido realizado da cuenta de que la mayor concentración de estudios sobre el clientelismo lo observan como un fenómeno político moderno. Para el caso colombiano es preciso advertir que si bien el carácter moderno está relacionado con la noción de Estado racional moderno y su aparato burocrático, también es factible observar algunas pautas o herencias previas de formas premodernas, asociadas a las relaciones patronales de la hacienda. Esta observación toma mayor fuerza cuando la unidad de análisis no es lo nacional, sino lo regional y lo local.

\subsection{Clientelismo de mercado}

El clientelismo de mercado es el tercer tipo que emerge tras las reformas introducidas al régimen bogotano a partir de 1991. Mauricio García Villegas señala que el clientelismo de mercado "tiene a los políticos como protagonistas y se vale de la existencia de nuevas

\footnotetext{
72 Comparar David Alberto Roll, Rojo difuso y azul pálido (Bogotá: Universidad Nacional de Colombia, 2002), 67.

${ }^{73}$ Comparar Valenzuela Ramírez, Producción, 35-37.

${ }^{74}$ Ibid., 35-37.
} 
reformas institucionales tales como la descentralización, la elección popular y los mecanismos de participación". ${ }^{75}$

La Constitución de 1991 propendía por la eliminación de todas las prácticas consideradas como atrasadas o clientelistas. Para tal efecto, en la carta política se consagraron medidas en pro de la apertura política del sistema y la profundización democrática del régimen. Nuevas fuerzas y movimientos aparecieron en la escena pública, gracias a la reducción de los umbrales electorales y la flexibilización de los requisitos de acceso a los órganos y cargos de elección popular. Por otra parte, la Constitución prohibió los mecanismos que se creían aceitaban la maquinaria clientelista (entre ellos, los auxilios parlamentarios); estableció incompatibilidades e inhabilidades que limitaban el acceso de políticos clientelistas; colocó topes a la financiación de las campañas electorales; creó el tarjetón e introdujo cambios en las circunscripciones de Senado y Cámara, entre otras disposiciones. Finalmente, la Constitución de 1991 intentó recuperar la función de control político del poder legislativo a partir de figuras como la moción de censura. Sin embargo, el cumplimiento de tales objetivos no logró la eliminación total del clientelismo, sino su adaptación a las nuevas realidades institucionales. ${ }^{76}$

El clientelismo de mercado, concretamente, se diferencia del moderno en que el líder no cuenta con un gran caudal electoral a nivel nacional, sino, por el contrario, es representante de una red más pequeña, particular y menos asimétrica. La competencia de los intermediarios (políticos) ha crecido, produciendo una gran capacidad de negociación por parte de los clientes. Los elementos ideológicos tienden a desaparecer. La naturaleza de los

\footnotetext{
${ }^{75}$ Ver García Villegas y Revelo Rebolledo, Estado, 24.

${ }^{76}$ Comparar Dávila Ladrón de Guevara y Delgado Varela, “La metamorfosis”, 328-332.
} 
recursos a intercambiar es tanto pública como privada. Este nuevo modelo, al fraccionar a los partidos en miles de redes clientelistas, ha sido denominado como el modelo de la "micro-empresa electoral". ${ }^{77}$ También, se observa que el clientelismo florece en la creación de otros tipos de identidad tales como la cultural e incluso la religiosa. ${ }^{78}$

El clientelismo de mercado es un fenómeno que hasta ahora sólo se ha analizado en Bogotá, a partir de la Constitución de 1991 y de la proclamación del Estatuto Orgánico que rige a la capital. Los estudios señalan que los cambios institucionales en Bogotá permiten vislumbrar una nueva faceta del clientelismo. En esta, el fenómeno se configura como una forma de hacer política que no está exenta de implementar participación ciudadana y representación política.

77 Comparar Eduardo Pizarro Leongómez, "La atomización partidista en Colombia: el fenómeno de las micro-empresas electorales", en Degradación o cambio: evolución del sistema politico colombiano, compilado por Francisco Gutiérrez Sanín (Bogotá: Editorial Norma, 2002).

${ }^{78}$ Comparar también Álvaro Cepeda Van Houten, Neopentecostalismo y política. El caso colombiano (Cali: Universidad de San Buenaventura, 2010); Lucía Eugenia Meneses, "La política Nasa y el clientelismo en el municipio de Páez, Cauca", Revista Colombiana de Antropología e Historia, 38 (2002): 105-130. 



\section{Modernidad, capitalismo y democracia: tres debates a propósito del clientelismo}

La revisión de las fuentes seleccionadas permitió identificar rasgos del fenómeno, al respecto de los cuales se ha generado un grado significativo de debate entre los diferentes autores. Aunque muchos de ellos no contaron con la posibilidad de poner a interactuar las ideas, a continuación se exponen algunas de las controversias despertadas a propósito del tema del clientelismo político entre los diferentes autores revisados. Como comentario adicional, se observa que los debates desarrollados también presentan una correspondencia con los periodos y las categorías ad hoc previamente desarrolladas (clientelismo tradicional, moderno y de mercado).

\subsection{El clientelismo, ¿fenómeno moderno o premoderno?}

Miranda Ontaneda estableció una relación entre tres elementos a saber: el capitalismo,la democracia y el desarrollo. Miranda planteó un paralelo entre un modelo de producción capitalista desarrollado y uno de capitalismo tardío: en el modelo en el que el capitalismo se muestra en una etapa desarrollada, la alta producción y los excedentes terminan siendo canalizados por el Estado por medio de los impuestos, lo que se traduce en bienes y servicios públicos ofrecidos a la totalidad de la población civil; en consecuencia, la oferta estatal da sustento al ejercicio de derechos de los ciudadanos. 
Está última característica se comporta como rasgo general de todo régimen democrático.

En contraste, otra situación es la que se describe cuando el capitalismo no está totalmente desarrollado. En este caso, la cantidad de bienes y servicios es escasa y, en consecuencia, el Estado realiza una asignación selectiva de los bienes y servicios públicos a través de intermediarios (gamonales, caciques, etc.), quienes, a su vez, realizan una repartición selectiva dentro de sus clientelas. Se forma, de este modo, una estructura piramidal y jerárquica. En la cabeza de esta estructura está el intermediario: el gamonal, quien mantiene la lealtad de sus clientes a través de la distribución que realiza. Si este orden no es reproducido por los clientes, los mismos pueden quedar excluidos de los servicios generados por el Estado. En este esquema, los servicios públicos son ofrecidos como dádivas y no como garantía de derechos. Por ende, el sistema democrático nunca llega a consolidarse más allá de su enunciación formal. ${ }^{79}$ En otras palabras, para Miranda Ontaneda, el capitalismo en Colombia estaba tomando un rumbo diferente al de los países desarrollados: este, al no desarrollarse a cabalidad creaba una situación de subdesarrollo, aspecto que afectaba proporcionalmente la idea de cualquier progreso económico. El estado precapitalista que el autor atribuye al país durante la década de los setenta lo condujo a plantear un choque entre modernidad y tradición, donde las relaciones clientelistas son asumidas como una forma típica de relación de sociedades atrasadas. Dentro de la lógica planteada por el auto, las relaciones capitalistas poco desarrolladas, observables para ese entonces en Colombia, se traducían en una asignación ineficiente de los bienes y servicios públicos; esto, a su vez, generaba la dificultad para la garantía de

${ }^{79}$ Comparar Miranda Ontaneda "El poder", 45. 
derechos plenos a la totalidad de la población y, en conclusión, toda una cadena de trabas o impedimentos para la consolidación de una democracia tal como era comprendida en su sentido ideal.

La mirada premoderna del clientelismo es cuestionada en trabajos como los de Fernán González, quien observa que este fenómeno se presenta en las burocracias modernas independientemente del grado de desarrollo económico presente en el Estado. En tal sentido, afirma que:

Algunos políticos como Alfonso López Michelsen han prestado poca atención al término considerándolo como un problema secundario de mecánica electoral al referirse a la campaña de Lleras Restrepo en 1976. Otros autores, como el politólogo Fernando Ulloa, lo consideran "no ya como un vicio colombiano propiciado por un determinado sector del partido liberal, sino como uno de los fenómenos que han sido característicos de la vida política aquí y en Cafarnaún". Anotaba Cepeda que el uso del término en el debate electoral dejó en muchos la impresión de ser un fenómeno exótico, peculiar, casi inventado por politiqueros mañosos y de fácil erradicación si triunfaban los sectores modernizantes. El fenómeno es bastante universal: el patrón otorga favores burocráticos a sus clientes a cambio de lealtad política y otros servicios, en una relación ciertamente desigual pero que favorece a ambas partes. Esta relación no es exclusiva del sector rural ni propia tan solo de sociedades atrasadas: se da en sectores urbanos y en las burocracias más sofisticadas a nivel nacional e internacional. ${ }^{80}$

${ }^{80}$ Ver González, “Clientelismo”, 68. 
El fenómeno muestra tener rasgos que lo posicionan como algo mucho más universal, que no se limita únicamente a la coyuntura electoral, sino que nutre el modo de operación de modelos burocráticos más modernos. No obstante, González matiza la anterior afirmación al señalar que si bien el clientelismo no es un fenómeno exclusivo de sociedades atrasadas, para el caso colombiano este sí se estructura sobre el conjunto de intereses regionales, que, a su vez, aún se articulan con sociedades tradicionales. ${ }^{81}$

\section{2. ¿Clientelismo como producto de la modernidad o como contradicción a la misma?}

El debate que se desarrollará a continuación tiene que ver con la relación que el clientelismo tiene con la modernidad, bien sea esta una relación pujante o una donde el clientelismo es un producto de la dinámica moderna.

Algunos autores han considerado el clientelismo como producto de un sincretismo entre lo tradicional y lo moderno. ${ }^{82} \mathrm{La}$ convivencia de elementos, modernos y tradicionales, presenta tensiones que han sido denunciadas como choques entre lo formal y lo informal, lo vicioso y lo virtuoso, que dan al régimen estabilidad e inestabilidad simultáneamente. Por ejemplo, de allí se explica que Colombia sea reconocida, en un ejercicio comparado con sus países vecinos, como uno de los más democráticos, y al mismo tiempo, sea vista como uno de los más excluyentes y oligárquicos a la vez. Desde esta postura, se acepta que el clientelismo es un

${ }^{81}$ Comparar González, "Apróximación a la configuración política de Colombia” (Controversia II, 1989), 37.

${ }^{82}$ Comparar también Torres Preciado, "Vicio", 5; Alfredo Antonio León Monsalvo, Penumbras y demonios en la política colombiana: un análisis sobre el clientelismo (Bogotá: Ediciones Desde abajo, 2011), 9; Escobar, Clientelism. 
aspecto presente en la modernidad aún cuando presenta contradicciones con la misma.

Sin embargo, otros análisis sobre el clientelismo han llevado a diluir al máximo el componente atávico del fenómeno, sosteniendo que el clientelismo es un fenómeno que se alimenta y reproduce de muchos de los elementos de la modernidad, dentro de los que se pueden enumerar la idea suprema de Estado; el funcionamiento de la burocracia; y la misma lógica bajo la que se plantea la democracia formal. A continuación se enunciarán cuáles han sido los argumentos que relacionan al clientelismo con cada uno de estos elementos modernos anunciados.

En primer lugar, John D. Martz parte de la hipótesis de que el clientelismo se configuró en la época moderna como un mecanismo para restablecer y mantener el control político y social, durante un momento de profunda transformación, a partir de mecanismos centralistas. No obstante, el autor reconoce que el fenómeno sí tuvo sus primeras manifestaciones en el seno de formas tradicionalmente rurales, presentes en épocas feudales y coloniales. De esta manera, el autor concibe al clientelismo moderno, no precisamente como un fenómeno opuesto al ideal de Estado racional moderno, sino como un producto del mismo.

John D. Martz sostiene que el imaginario de modernidad se desarrolló alrededor de la idea de un Estado como patrón máximo o final. Esta idea tuvo unos desarrollos de alto alcance en el mundo entero, en tanto que el Estado fue asumido como la institución dominante de la sociedad. Pronto, el Estado se convirtió en la unidad de montaje para la modernización y el desarrollo, $\mathrm{y}$ las funciones necesarias para el ejercicio de su gobernabilidad fueron ampliadas de forma exponencial. Con el advenimiento del Estado burocrático se generó un centralismo pronunciado, generando una ruptura de las lealtades regionales y locales. E1 Estado 
se convirtió en el proveedor de infraestructura en áreas como el transporte, las comunicaciones y en el responsable de la diversificación económica. ${ }^{83}$ En medio de las trasformaciones sociales vividas a raíz de la migración campo-ciudad y el paso de una sociedad agraria a una industrial, el clientelismo cobró un rol fundamental. En palabras del autor, "el establecimiento y la defensa, o el colapso y la renovación de la capacidad de ejercer control social y político han sido dependientes de los mecanismos clientelistas" 84 desde entonces. Por otro lado, sostiene el autor, la misma noción de Estado, por sus características, es un concepto proclive al desarrollo de relaciones clientelistas. Es decir, el carácter jerarquizado del Estado, su organización centralizada y su creciente control monopolizado sobre los recursos hace que quienes estén más cerca al poder puedan tener un beneficio mayor de los recursos. Esta naturaleza innata del Estado moderno, mezclado con los bajos niveles de participación, hacen que el clientelismo se configure como un mecanismo eficiente para expandir las funciones del Estado cuando la comunicación con la ciudadanía se ve impedida. En este orden de ideas, los mecanismos democráticos establecidos a través del voto dejan de ser funcionales a los principios de participación y representación, para trabajar en función del mismo clientelismo burocrático. ${ }^{85}$

Ahora bien, David Roll argumenta que la racionalidad weberiana del Estado Moderno en el Estado clientelista queda reducida a su mínima expresión cuando las órdenes de los funcionarios no vienen de cargos administrativos sino políticos. ${ }^{86}$ Sin embargo,

\footnotetext{
${ }^{83}$ Comparar Martz, The Politics, 12.

${ }^{84}$ Ibid., 12. Traducción hecha por la autora del trabajo.

${ }^{85}$ Ibid., 315.

${ }^{86}$ Comparar Roll, "El clientelismo”, 118-119.
} 
Steffen W. Schmitt señala que la burocracia weberiana, tal como fue planteada en sus inicios, es un modelo ideal que nunca va a corresponder con la realidad de facto. En consecuencia, la burocracia técnicamente mejor desarrollada no necesariamente es funcional a las órdenes que vienen desde arriba sin ninguna disposición a la defensa de programas propios o impersonales. Para el autor, "el burócrata moderno puede de hecho, ser caracterizado por ser formalmente 'impersonal'. Sin embargo, si su sistema social es aquel en el que los vínculos clientelistas son perseguidos, puede encontrarse obligado a establecer estos vínculos por sí mismo para lograr los planes técnicos que desea" ${ }^{87}$ Es decir, la racionalidad weberiana existe, sin embargo, en la medida en que la burocracia es ejecutada por seres humanos, hay un pequeño margen de acción donde no opera la ley o las órdenes desde arriba, sino una racionalidad guiada por un impulso personal o clientelista. Por esto mismo, la burocracia es el segundo de los aspectos de la modernidad que se adapta bien a las dinámicas clientelistas.

En tercer lugar, todos pensamos que la modernización de las instituciones políticas implicaba necesariamente su democratización. ${ }^{88}$ No obstante, la modernización que llegó a Colombia, formulada por Lleras Restrepo, no estaba planteada en términos de democracia o mínimos de igualdad social, sino en términos de progreso económico. De hecho, retomando planteamientos de Martz, el sistema político colombiano es por definición un sistema político excluyente y tal adjetivo nunca fue un impedimento para que el bipartidismo se desplazara hacia procesos que llevaron al Estado

\footnotetext{
${ }^{87}$ Ver Schmidt, "Bureaucrats”, 425-450. Traducción hecha por la autora del trabajo.

${ }^{88}$ Comparar David Alberto Roll, Inestabilidad y continuismo en la dinámica del cambio politico en Colombia: perspectiva de la reforma politica en Colombia desde 1930 hasta 1991 (Bogotá: ICFEs, 1999), 19-20.
} 
hacia su modernización. Empero, el gran choque se produjo entre los partidos y el paradigma mismo de modernidad, cuando el proceso de modernización del Estado empezó a integrar formas incluyentes de participación mediante la adopción de un sistema democrático. La democratización fue, por tanto, el gran enemigo del poderío que habían adquirido los dos partidos políticos. Lo anterior conlleva a cuestionarse lo siguiente: si el desarrollo colombiano no estaba planteado en términos democráticos, ¿cuál debió haber sido el camino tomado por los partidos?, ¿existen choques que se dan entre las formas tradicionales de hacer política, el sistema democrático y el modelo de modernidad adoptado por Colombia? Todos estos elementos permiten concluir que Colombia en efecto no ha terminado su proceso de construcción de Estado y que en dicho proceso la adopción de valores universales, tal como han sido planteados por el sistema occidental, no son el camino más conveniente para una sociedad como la colombiana. Esto, en la medida en que el paradigma moderno es producto de unas circunstancias culturales, históricas y sociales que se vivieron en Europa. Colombia, al tener unas realidades diferentes a las europeas, adoptó el paradigma con algunas variaciones que terminó por producir choques entre sus formas tradicionales de operación y los procesos universales que fueron importados. Por tanto, Colombia se encuentra en un momento en el que debe empezar a diseñar modelos que se adecuen a sus procesos históricos y culturales.

De esta manera, se encuentra que definitivamente el clientelismo es parte esencial de la política moderna, en tanto que los partidos no podrían sobrevivir sin los incentivos a los votantes y simpatizantes y eso, inmediatamente, produce repercusiones en los planes y programas de gobierno a nivel burocrático. Sin embargo, el clientelismo burocrático es mucho más proclive en sistemas 
oligárquicos y excluyentes donde no hay niveles óptimos de participación ciudadana. De tal manera, aun cuando se intenten implantar mecanismos formales de democracia, el efecto seguido es una instrumentalización del voto y de todo el sistema democrático en su aspecto formal, por lo que el Estado, su burocracia y los mecanismos democráticos establecidos por la ley terminan por configurarse como elementos funcionales al sistema clientelista.

\subsection{Clientelismo y democracia, ¿un imposible?}

Cuando se habla de democracia y de clientelismo, se parte del presupuesto de que estos son dos términos excluyentes: o hablamos de democracia o hablamos de clientelismo. En efecto, algunos autores sostienen que pensar desde el mundo de las clientelas produce una distancia abismal con respecto al mundo regido por la ley, la ciudadanía y la democracia. ${ }^{89}$ Para muchos, el clientelismo es un fenómeno que facilita la fragmentación de la ciudadanía, puesto que individualiza y privatiza los intereses, descolectiviza las demandas y aliena la función de control político que debe ser ejercida por la sociedad civil. ${ }^{90}$

Por otro lado, John D. Martz planteó un escenario alternativo al clientelismo a partir del fortalecimiento de la democracia substancial, desde el cual se propone propiciar una verdadera dinámica de competencia política entre partidos, que rompa con los personalismos y genere una dinámica del voto programático. En este orden de ideas, se propiciaría un trabajo conjunto entre el sector

\footnotetext{
${ }^{89}$ Comparar tambien García Villegas y Revelo Rebolledo, Estado, 33; Roll, "E1 clientelismo”,114-128; Miranda Ontaneda, Clientelismo,i;Juan David Guevara Salamanca, "La democracia participativa como instrumento de dominación de la esfera pública. Una mirada crítica a la realidad política colombiana a partir de la constitución de 1991" (trabajo de grado, Universidad del Rosario, Bogotá, 2009), 3.

${ }^{90}$ Comparar Guevara Salamanca, "La democracia", 23.
} 
privado y el público en la formulación de políticas, se fortalecería lo local y se buscarían mecanismos alternos para la resolución del conflicto. ${ }^{91}$ Sin embargo, ya se ha visto cómo la proclamación de la nueva carta política no logró el cometido, un tanto ideal, de la instauración de una democracia en su sentido substancial. Esto se debe a que el clientelismo se vale de los mecanismos formales para poder reproducirse e impide que los valores democráticos se desarrollen a cabalidad. Gilberto Alzate Cardona, al respecto, indica que la cultura de la participación política colombiana se pone en entre dicho cuando se descubre que el derecho al sufragio en Colombia se compone por quienes tienen las capacidades sociales y económicas para tener un voto de opinión; por quienes debido a la precariedad de sus condiciones económicas venden su derecho al voto a cambio de algún tipo de contraprestación; y por quienes deciden no votar, ya que tal acción no representa beneficio alguno. ${ }^{92}$

Por su parte, Andrés Dávila plantea un escenario alternativo al señalar que la intermediación clientelista tiene una dimensión de representación política que no debería ser menospreciada. ${ }^{93}$ En adición, Cristina Escobar afirma que el clientelismo no es necesariamente ni una interrupción a la movilización social, ni tampoco un vehículo para la democratización ${ }^{94}$ y Fernán González anota que:

\footnotetext{
${ }^{91}$ Comparar Martz, The Politics, 318.

${ }^{92}$ Comparar Alzate Cardona, Concentración de poder, violencia, clientelismo y democracia participativa en Colombia (Bogotá: Pontificia Universidad Javeriana, 1995), 347.

${ }^{93}$ Comparar Dávila Ladrón de Guevara, "Clientelismo, intermediación”, 62.

${ }^{94}$ Comparar Jaramillo, Clientelismo y poder: relectura, 29.
} 
Esta paradoja obliga a considerar que el problema de la viabilidad de la democracia y de su eventual colapso o fracaso en Colombia puede afrontarse desde tres puntos de vista: a. Desde un modelo ideal y abstracto de democracia, generalmente bastante idealizado, tomado de la experiencia de los Estados nacionales solidados de Occidente que se pone a prueba en nuestros subdesarrollados sistemas y países; $b$. Desde una visión idealizada de un pasado donde reinaba la armonía y el orden, una mítica edad de oro donde los valores cívicos y cristianos eran respetados, la ley era observada y las instituciones estatales tenían pleno control de la sociedad, desde la cual el presente se ve como decadencia o caída, pérdida del monopolio estatal de la fuerza; c. Desde un proceso paulatino y conflictivo de construcción de las instituciones del Estado, que poco a poco va integrando las diferentes regiones del territorio nacional y articulando sus respectivas poblaciones al conjunto de la vida nacional, construcción del monopolio estatal de la coerción legítima que implica también la gradual. ${ }^{95}$

De esta manera, las trasformaciones al régimen político a partir de la Constitución de 1991 permiten evidenciar una faceta del clientelismo que antes no había sido tenida en cuenta. Este nuevo momento conduce a pensar que el proceso de construcción del Estado colombiano no es de ninguna forma algo ya acabado, por el contrario, esta coyuntura señalada con respecto a la forma de percibir el fenómeno abre camino hacia nuevos modelos de

${ }^{95}$ Ver González, “CColapso parcial o presencia diferenciada del Estado en Colombia? Una mirada desde la historia”, Colombia Internacional (2003): 126-127. 
Clientelismo POlítico, ¿DESVIACIÓN DE LA POLÍTICA O FORMA DE REPRESENTACión?

democracia que se adapten a las circunstancias y procesos particulares de sociedades como la colombiana. 


\section{Análisis político sobre la emergencia de los estudios de clientelismo}

Los estudios sobre clientelismo en Colombia no han estado desarticulados del contexto histórico-político del país. La puesta en escena de este fenómeno como unidad de análisis y su respectiva problematización, desde diversos enfoques, da cuenta e interactúa, también, con luchas políticas e ideológicas vivenciadas en las últimas décadas. No es de interés del presente trabajo realizar un análisis de corte historiográfico sobre la política nacional desde la segunda mitad del siglo $\mathrm{xx}$, pero sí presentar aquellos eventos diagnósticos que ayudan a comprender el contexto en el cual se producen los estudios del clientelismo en Colombia. ${ }^{96} \mathrm{El}$ presente capítulo trabajará cuatro eventos diagnósticos: i) el período del Frente Nacional (1958-1974); ii) el desmonte del citado régimen y la consecuente crisis del bipartidismo; iii) la reforma política de 1968; y iv) la Constitución política de 1991.

\footnotetext{
${ }^{96}$ Estas coyunturas son una suerte de eventos diagnósticos. Se entiende por estos eventos aquellos momentos históricos que "revelan tanto competencias, contradicciones y conflictos que están sucediendo como los esfuerzos para prevenirlos, suprimirlos o reprimirlos". Ver María Clemencia Ramírez, Entre el Estado y la guerrilla: identidad y ciudadanía en el movimiento de los campesinos cocaleros en Putumayo (Bogotá: Instituto Colombiano de Antropología e Historia-Colciencias, 2001), 20.
} 


\subsection{Frente Nacional}

Los partidos tradicionales cumplen un papel fundamental en la historia y devenir político de Colombia desde el siglo xix. De acuerdo con Fernán González, cuando el Estado colombiano no tenía presencia, ni control, sobre la totalidad de su territorio, los partidos se encargaron de crear identidades más allá de las locales o regionales e integrar las clases populares a la vida política nacional, a través de las clientelas. Esta inclusión vertical desde arriba fue un modo para superar la fragmentación del territorio colombiano y posibilitar que algunos intereses regionales fueran agenciados por la burocracia central, superando, en parte, problemas de indiferencia $\mathrm{y}$ frialdad de la tecnocracia nacional con respecto a las demandas $\mathrm{y}$ reivindicaciones locales.

En aquel entonces, para González, la inclusión de las clientelas en la política nacional no representaba una amenaza para la estabilidad del régimen político. Por el contrario, este mecanismo permitió la legitimación electoral de los partidos y de los gobiernos posteriores. ${ }^{97}$

Ahora bien, la escasez de bienes públicos y la precariedad estatal en lo local fomentaron la competencia interpartidista por el acceso a los recursos públicos y el mantenimiento de las redes clientelares. En este contexto, la inscripción y adhesión partidista era un asunto vital en las regiones, pues generaba sentido de pertenencia, proveía identidad política y aseguraba el acceso a bienes y servicios públicos limitados. No en vano, los partidos Conservador y Liberal se comportaron como intransigentes subculturas que imposibilitaron la creación de un proyecto nacional

${ }^{97}$ Comparar González, ¿Colapso?”, 137. 
unificado, pese a que lograron trascender en ocasiones las fronteras regionales. ${ }^{98}$

El bipartidismo imprimió, desde entonces, unas características que diferencian el sistema político colombiano de otros sistemas en el continente. Según David Roll, en Colombia existen mecanismos de mediación clientelista, enraizados en los partidos tradicionales, junto con un modelo de democracia formal, restringida y excluyente. Esta combinación le imprime al régimen un rasgo de estabilidad y continuismo en contraste con otros países latinoamericanos. ${ }^{99}$ No en vano, Colombia fue uno de los pocos países sin dictaduras de largo alcance y sin movimientos populistas de gran envergadura. ${ }^{100}$ Daniel Pecaut, por su parte, observa que el clientelismo colombiano se configuró como un mecanismo de asociación política que imposibilitó la existencia de populismos, la creación de un proyecto nacional y la búsqueda de soluciones para los problemas sociales que enfrentaba la violencia rural y urbana. ${ }^{101}$ Marco Palacios refuerza esta idea señalando que el fracaso de movimientos populistas de ideología de izquierda en Colombia, tales como el gaitanismo y el anapismo, no se explica por la intervención de unas fuerzas armadas, sino por el funcionamiento del

\footnotetext{
${ }^{98}$ Comparar Roll, Rojo, 57.

${ }^{99}$ Comparar Roll, Rojo, 57.
}

${ }^{100}$ El único gobierno colombiano considerado bajo el título de dictadura fue el de Gustavo Rojas Pinilla, el cual tuvo lugar de 1953 a 1957, para luego ser remplazado por una junta militar de un año, instaurada para la transición a la democracia. Esta dictadura fue la base para la construcción del régimen de coalición denominado Frente Nacional. Se dice que Colombia no presentó dictaduras de largo alcance, puesto que esta excepcionalmente corta dictadura no es comparable con otros regímenes militares del continente.

${ }^{101}$ Comparar Daniel Pecaut, "Populismo imposible y Violencia: El caso colombiano", en Guerra contra la sociedad (Bogotá: Editorial Planeta Colombiano, 2001), 53- 86. 
sistema político bipartidista. ${ }^{102}$ Es decir, el clientelismo imprimió en el país unos rasgos particulares que marcaron una diferencia de la vida política nacional con respecto a otros procesos políticos latinoamericanos, evitando los caudillismos o las dictaduras militares que marcaron su historia.

En la década de 1930 a 1940, el país entró en un proceso de modernización económica donde los partidos políticos tradicionales pasaron a ser canales de captación de masas que terminaron por producir un equilibrio. Sin embargo, la intransigencia de sus dirigentes e ideólogos terminó por conducir al país a una guerra entre las subculturas políticas que dio origen al período histórico conocido como la Violencia en Colombia. ${ }^{103}$

El cierre de este período, paradójicamente, se da a partir de pacto suscrito por las élites políticas liberales y conservadoras para poner fin a su enfrentamiento. La fórmula acordada inaugura el período del Frente Nacional en el país (1958-1974). Sobre el tema, David Roll anota que le siguió a "la reanudación de la violencia y esa utópica ambición de Rojas Pinilla de sustituir un bipartidismo pujante y conflictivo". ${ }^{104}$ Sin embargo, paradójicamente, esa misma capacidad de movilización ciudadana que habían tenido los partidos fue la misma que luego se vio socavada cuando el Acto Legislativo Numero 1 de 1959 consagró la alternancia presidencial. ${ }^{105}$ De esta manera, se pactaron, sin consultar al constituyente primario, los principios de alternancia y paridad

${ }^{102}$ Comparar Marco Palacios, "Presencia y ausencia de populismo: para un contrapunteo colombo-venezolano", en Populistas, mandarines y violencias. Luchas por el poder (Bogotá: Editorial Planeta Colombiano, 2001), 45-81.

${ }^{103}$ Comparar también Roll, Rojo; Jaime Arocha Rodríguez, "Clientelismo, gasteo y violencia”, Enfoques colombianos, (1980); Archer, The Transition; Martz, The Politics.

${ }^{104}$ Ver Roll, Rojo, 57.

105 Ibid., 58. 
política entre los dos partidos tradicionales. Estas reglas del juego determinaron formalmente la vida política del país durante los siguientes 16 años. ${ }^{106}$

Pronto, la repartición burocrática terminó por desideologizar a los partidos. El régimen del Frente Nacional no sólo evidenció su incapacidad para crear programas competitivos, sino también, para buscar mecanismos de inclusión de nuevos sectores, por supuesto más amplios que los meros clientelares. ${ }^{107}$ Implicó, por tanto, la pérdida de la capacidad de cooptación y arrastre electoral de los partidos tradicionales y evidenció el carácter restringido de sus clientelas y la incapacidad e inconsistencia para generar un proyecto democrático que superara las coyunturas electorales.

Para John D. Martz, Colombia adoptó un sistema político excluyente e implantó estructuras formales que se ajustaban a la definición ortodoxa de democracia, pero con un pluralismo restringido, una predominancia del ejecutivo, un estilo patrimonial de regulación y una ausencia marcada de ideologías. ${ }^{108}$

\subsection{Crisis del bipartidismo}

La noción de crisis alude a dos fenómenos independientes, pero estrechamente interconectados: i) la crisis de los partidos tradicionales que estalló, con fuerza, en la década de los ochenta y ii) la pérdida de legitimidad del sistema político, en su conjunto, derivada en buena parte del Frente Nacional. Vale recordar que los partidos

${ }^{106}$ Comparar Jonathan Hartlyn, La politica del régimen de coalición (Bogotá: Tercer Mundo y Universidad de los Andes, 1993). Quizás se trata del estudio más sistemático sobre el Frente Nacional y, aunque hace referencia al clientelismo como fenómeno histórico, no parece ser una preocupación central del autor.

${ }^{107}$ Comparar Roll, Rojo, 75.

${ }^{108}$ Comparar Martz, The Politics, 38. 
tradicionales se convirtieron en los protagonistas exclusivos de la historia política y, por tanto, la alteración de los mismos repercutía en el sistema político en general. ${ }^{109}$

Los partidos no entraron a la modernización política ni se sintonizaron con las transformaciones culturales y la modernización económica que vivió el país en las seis primeras décadas del siglo xx. ${ }^{110}$ Ellos se acostumbraron a reproducirse a través del mecanismo de inclusión vertical. La alternancia del poder y la minuciosa repartición burocrática del Frente Nacional les aseguraba un espacio para sus clientelas. Sin embargo, esta fórmula no daba respuesta a los malestares y demandas de vastos sectores urbanos, que empezaban a hacer presencia en la esfera pública del país. ${ }^{111}$ Pronto se observó que sólo los ciudadanos con intereses de por medio acudían a las urnas. En consecuencia, el clientelismo y el uso de los recursos estatales rápidamente se esgrimieron como las modalidades empleadas por los partidos para la recuperación del control político. Sus esquemas clientelistas aseguraban la continuidad en el poder político y, simultáneamente, acrecentaba la distancia con las demandas políticas del país emergente. El vacío de representación pudo haber sido un detonador de la apatía y el abstencionismo, así como de la opción de la vía armada como mecanismo para propiciar cambios en el sistema político.

La no sintonía del país político con los cambios que demandaba el país real se acrecentaba aún más en el escenario legislativo. Las iniciativas transformadoras y otras se veían truncadas debido a que todas ellas requerían de mayoría calificada y no simple. Este modo de elección se instauró en el Frente Nacional con el

\footnotetext{
${ }^{109}$ Comparar Roll, Rojo, 57.

${ }^{110}$ Comparar Jaramillo, Clientelismo y poder: relectura, 29.

${ }^{111}$ Comparar Roll, Rojo, 56.
} 
objetivo de evitar conflictos bipartidistas. Sin embargo, la medida pronto se tradujo en una situación sostenida de ingobernabilidad.

\subsection{Modernización y reforma del 68}

La idea de cambiar el sistema fue capitalizada por el presidente liberal Carlos Lleras Restrepo (1966-1970). A pesar de las trabas del legislativo, se logró impulsar la reforma constitucional de 1968. La reforma perseguía la modernización del país. Para tal efecto, se buscó fortalecer la orientación del ejecutivo, previo proceso tecnocrático de planeación, en detrimento del poder legislativo. ${ }^{112}$ Sin embargo, su aprobación no fue fácil: esta se surtió de una fuerte oposición por parte de los parlamentarios. ${ }^{113}$ Por ende, para su trámite exitoso se les concedieron privilegios que les aseguraran las curules y el acceso a bienes públicos vía mecanismos clientelares. ${ }^{114}$ Así, la reforma aseguró la reproducción de redes clientelistas vía la creación de los llamados auxilios parlamentarios, ${ }^{115}$ los cuales financiaron campañas reeleccionistas de los congresistas y el mantenimiento de redes clientelares. ${ }^{116}$

La reforma del 68, además, permitió dar continuidad a la fórmula de partición proporcional. ${ }^{117} \mathrm{Y}$ si bien esta generó cambios de gran envergadura en el régimen constitucional anterior, también marcó el comienzo de una forma de operación particular del

${ }^{112}$ Comparar González, “Clientelismo”, 85.

113 Ibid., 85.

${ }^{114}$ Comparar Roll, Inestabilidad,18-19.

${ }^{115}$ Partidas presupuestales para el desarrollo de proyectos que solucionaran problemáticas, necesidades y demandas de cada una de las circunscripciones electorales, pero cuyo gasto era discrecional de los congresistas

${ }^{116}$ Comparar Martz, The Politics, 291.

${ }^{117}$ Comparar Roll, Inestabilidad, 301. 
Congreso. Por ende, en este contexto, no se logró una plena modernización del régimen político y, por el contrario, se afianzó el clientelismo como modo de operación del sistema político. Sus resultados enquistaron unas élites políticas y económicas lejanas a la ciudadanía, que en general desconfiaban de los políticos y no se sentían representadas por los partidos. La crisis de legitimidad del régimen político era cada vez más evidente.

Por otra parte, la reforma del 68 generó una división (discursiva) de la clase política nacional. La división liberales versus conservadores cedió el terreno a la realizada entre políticos tecnócratas, asociados al país económico, la rama ejecutiva del poder público y el discurso modernizante de la política, versus políticos clientelistas, asociados al bipartidismo de corte rural, regional y a la rama legislativa con tonos más arcaicos en el quehacer político. No en vano, en aquel entonces, los integrantes de la Comisión del Plan en el Congreso tildaban de clientelistas a sus opositores. ${ }^{118}$ En este orden discursivo, los cuerpos colegiados pronto pasaron a ser considerados como el principal impedimento para el desarrollo del país. De esta manera, el clientelismo emerge como un mecanismo de reproche mutuo entre partidos, al igual que un objeto visible y de gran envergadura del sistema político colombiano.

Según Martz, no se puede desconocer que mientras el Frente Nacional estuvo vigente, este procuró la estabilización de la democracia en su sentido formal. Sin embargo, los aspectos rescatables del pacto no fueron suficientes para superar los aspectos indeseables del mismo. En consecuencia, en 1968 se inició el proceso de su desmonte ${ }^{119}$ con el fin de desvincular la participación de los

${ }^{118}$ Comparar Alfonso Miranda Talero, "Del manzanillismo al clientelismo presupuestal", Areopago, 2 (1987): 24.

${ }^{119}$ Comparar Martz, The Politics, 36. 
partidos políticos de la toma de las decisiones estatales. ${ }^{120}$ Aun cuando el desmonte se inició en 1968, muchas de las dinámicas establecidas durante este pacto se perpetuaron de facto hasta la década de los ochenta.

\subsection{Constitución de 1991}

El discurso anti-clientelista, el de la paz y el de una democracia efectiva fueron el motor para adelantar las reformas políticas de finales de los años ochenta y principio de los años noventa (reforma constitucional de 1986 y Constitución política de 1991). Si bien Colombia no había vivido una dictadura instaurada por un largo periodo de tiempo, sí se hablaba en aquel entonces de una democracia más formal que real, excluyente y restringida. Para entender la magnitud del fenómeno es fundamental saber cómo funcionaba el sistema antes de 1991. Para lo cual, Rodrigo Losada señala:

[...] es conviene recordar cuál era la práctica anterior a 1991: el candidato al Senado hacía alianzas con uno o más candidatos a Cámara, y a través de éstas, o él directamente, pactaba también alianzas con uno o más candidatos a Asamblea y con uno o más candidatos a Concejos en varios municipios del departamento. Se conformaban pirámides de alianzas, en las que todos los integrantes se fortalecían, o esperaban lograrlo. De hecho, quienes más se beneficiaban de estas alianzas eran quienes las coronaban, o sea, los grandes caciques regionales. ${ }^{121}$

\footnotetext{
120 Ibid., 309.

${ }^{121}$ Rodrigo Losada, "Reformas regresivas: las reformas electorales propuestas por el gobierno solo favorecen a los caciques y al clientelismo", Dinero, septiembre, 1996. Este artículo es importante en la medida en que muestra cuáles fueron los puntos de discusión a
} 
La Constitución de 1991 consagró reformas electorales que tenían como objetivo romper con la estructura piramidal y clientelista anteriormente descrita. El resultado inesperado de las mismas fue un aumento del abstencionismo, la aparición del voto de opinión y, consecuentemente, la reducción aparente del voto clientelista. Si bien la nueva carta política eliminó las bases de grandes caciques regionales, también dio origen a pequeñas redes locales con capacidad limitada de movilización de recursos, mejor conocidas como micro-empresas. ${ }^{122}$ Esta ruptura con la estructura piramidal clientelista es lo que ha sido denominado el colapso de la maquinaria política. ${ }^{123}$

La entrada en vigencia de la Constitución política de 1991, en Colombia, generó limitación a las prácticas clientelistas de los políticos tradicionales, gracias a medidas tales como: i) la eliminación de los auxilios parlamentarios; ii) la aparición del tarjetón en sustitución de la papeleta y iii) el control sobre los recursos manejados discrecionalmente por los políticos. Esto, si bien tenía como objetivo erradicar el clientelismo, antes que hacerlo de raíz,

propósito de la reforma electoral. Lo más importante es que el autor permite identificar que las teorías democráticas propuestas por autores como Robert Dahl y Giovanni Sartori son contradictorias con las prácticas políticas tradicionales en Colombia. Dentro de los temas de coyuntura del momento se encuentran: el voto obligatorio, la unificación del calendario electoral y la prolongación del periodo de las autoridades electivas electorales regionales.

122 "Las micro-empresas electorales son la expresión en el plano electoral de las facciones personalistas que, en su sumatoria de representaciones fragmentadas, conforman un conjunto heterogéneo que todavía se llama partido (Liberal o Conservador, con mayúsculas). También son el instrumento de expresión electoral de múltiples movimientos o micro-partidos no adscritos a los partidos tradicionales para ingresar al juego político-electoral”. Ver Pizarro Leongómez, "La atomización”, 357.

${ }^{123}$ Comparar también Santos Villagrán, "Bogotá”, 13. 
suscitó la trasformación del fenómeno, pasando del anterior clientelismo corporativo (moderno) a uno más de tipo de mercado. ${ }^{124}$

La reforma no eliminó las prácticas clientelistas. Por el contrario, lo que se presenció fue una adaptación de las mismas a las nuevas realidades institucionales. A manera de ejemplo, los auxilios parlamentarios pronto fueron remplazados por los fondos de cofinanciación, figura que fue utilizada por el ejecutivo como un mecanismo para dar prebendas al legislativo a cambio de votos favorables a sus iniciativas. ${ }^{125}$

El recorrido por el contexto político permite esgrimir a manera de hipótesis de trabajo que el clientelismo (en sus diferentes modalidades: tradicional, moderno o de mercado) ha estado estrechamente articulado con el sistema político colombiano. Este fenómeno se ha alimentado del sistema y en su desarrollo le ha generado improntas significativas, que lo caracterizan y particularizan. La relación del clientelismo y el bipartidismo, en el marco de una democracia formal, pero excluyente, es notoria. En este contexto, el clientelismo toma rasgos de fenómenos como el caciquismo y patronazgo, pero no se reduce a estos. Por el contrario, se observa que el clientelismo cumplió una función de articulación de lo local y lo nacional a través del régimen bipartidista, evitando la diferenciación de los proyectos políticos y perpetuando subculturas que no lograron sintonizarse con los procesos de modernización demandados; de manera opuesta, los partidos tradicionales terminaron generando lo que se conoce como la Violencia Política. La superación de este período se dio mediante un pacto y arreglo institucional que le dio más oxígeno y vida al clientelismo político

${ }^{124}$ Comparar también Gutiérrez, "Clientelismo y sus enredos”; Dávila Ladrón de Guevara, "Clientelismo, intermediación”, 62-78.

${ }^{125}$ Comparar Roll, Rojo, 73. 
en Colombia. El desmonte del Frente Nacional implicó no sólo superar la división antagónica entre los partidos Liberal y Conservador, sino también trajo consigo una nueva división entre políticos técnicos, modernizantes y próvidos para lo público versus políticos clientelistas, atávicos y con tintes de corruptos. Emerge, entonces, un discurso anti-clientelista que influenciaría muchos de los estudios producidos a lo largo de los años ochenta e, incluso, la reforma constitucional de 1991. Es por ello que, antes de 1991, los estudios sobre clientelismo presentan un visión preeminentemente negativa del mismo. Sin embargo, la adaptación del fenómeno a las nuevas realidades constitucionales, permite inferir que el sector autodefinido como no-clientelista no estaba exento de utilizar prácticas similares. Por lo anterior, cualquier reforma institucional que busque la eliminación del fenómeno, antes que dar muerte al mismo, parece generar su trasformación y rápida adaptación a las nuevas reglas. 


\title{
6. ¿Clientelismo como desviación de la política o como forma de representación?
}

\begin{abstract}
Algunos autores discuten que el clientelismo es un fenómeno que se nutre de elementos contradictorios, que en ocasiones chocan entre sí. Sin embargo, es el conjunto de estos elementos opuestos, contradictorios y disímiles, lo que al mismo tiempo facilita sus formas de reproducción. Para Cristina Escobar, el clientelismo "combina asimetría e inequidad con solidaridad, coerción con participación voluntaria, ilegalidad con imágenes públicas de poder y continuidad con inestabilidad". ${ }^{126}$ En esta línea, Javier Fernando Torres atribuye al clientelismo elementos que él denomina virtuosos y, simultáneamente, viciosos.
\end{abstract}

Paradójicamente, el clientelismo ha contribuido a la ya histórica debilidad estatal, y a su vez ha permitido que el pueblo se sienta "incluido" en el juego político. En esta medida, ha permitido cierta estabilidad y funcionamiento a las instituciones, aunque no de la manera adecuada. El clientelismo ha sido un mecanismo perverso, por lo que significa en términos de debilitamiento de las instituciones democráticas, pero útil como eje de la política regional y local. ${ }^{127}$

${ }^{126}$ Ver Escobar, Clientelism, 37.

${ }^{127}$ Ver Torres Preciado, “Vicio”, 107. 
La existencia de dichos elementos ha conducido a que los estudios sobre clientelismo oscilen en dos grandes tendencias o aproximaciones. A un extremo del espectro se encuentran los autores que atribuyen al clientelismo y a las redes patrón-cliente un carácter moralmente indeseable o "malévolo", con consecuencias negativas para el sistema político inexploradas. ${ }^{128} \mathrm{Al}$ otro extremo, están quienes hacen hincapié en aspectos "positivos" del clientelismo, argumentando que este es un canal de distribución y de movilidad social, un mecanismo de representación política y de construcción de una res pública ${ }^{129}$, al igual que una fuerza estabilizadora entre partidos. ${ }^{130}$

\subsection{Clientelismo como desviación}

En Colombia, los estudios sobre clientelismo político se han inclinado más por observarlo en clave negativa, desde enfoques como el institucionalista y el marxista, predominantes en los años setenta y ochenta. Para los institucionalistas, el clientelismo está fuertemente ligado a la corrupción, el debilitamiento de la institucionalidad y el detrimento del ejercicio democrático. Para los marxistas, el clientelismo se observa como un mecanismo de instrumentalización

${ }^{128}$ Comparar también Roll, Rojo; García Villegas y Revelo Rebolledo, Estado; Luis

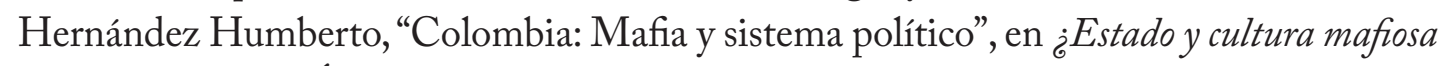
en Colombia?, ed. Óscar Mejía Quintana, (Bogotá: Universidad Nacional de Colombia, Facultad de Derecho, Ciencias Políticas y Sociales, Instituto Unidad de Investigaciones Jurídico-Sociales Gerardo Molina, 2010), 127-147.

${ }^{129}$ La Res Pública es una expresión del latín que denota la cosa pública.

${ }^{130}$ Comparar también Archer, The Transition, 4-5; Dávila Ladrón de Guevara, "Clientelismo, intermediación”, 62-78; García Sánchez, “La política”; García Sánchez, ¿Ciudadanía avergonzada?; Francisco Gutiérrez Sanín, "Historia de democratización anómala: el partido Liberal en el sistema político colombiano desde el Frente Nacional hasta hoy”, en Degradación o cambio: evolución del sistema politico colombiano, comp. Francisco Gutiérrez Sanín (Bogotá: Editorial Norma, 2002), 25-78; Rubio Serrano, No hay paraísos. 
del ser humano. Entre los institucionalistas que observan al clientelismo en clave negativa se puede citar a David Roll, Mauricio García y Javier Revelo. Roll asegura que:

El clientelismo es una especie de corrupción a tres bandas, pues al mismo tiempo que afecta negativamente los bienes y servicios públicos, al feriarlos, perjudica un bien no patrimonial del Estado -la representación-,y por añadidura contribuye a generar una cultura de la corrupción, la cual se expresa en actos diferentes pero inspirados en el mismo anti principio de la preeminencia del interés particular sobre el colectivo. ${ }^{131}$

García y Revelo, por su parte, aseguran que dentro de la institucionalidad colombiana hay un clima proclive a ver el clientelismo como norma superior debido a la función distributiva que cumple. ${ }^{132} \mathrm{~A}$ pesar de eso, la asociación entre corrupción y clientelismo hace que la atribución de prácticas clientelistas a políticos genere inmediatamente el detrimento de su imagen y de su buen nombre. En este orden, la Constitución de 1991 y la reforma electoral de 2003 tenían como objetivo dar muerte al fenómeno del clientelismo; pero, como se ha visto, estas producen su adaptación y no eliminación. Andrés Dávila replica que la cercanía del clientelismo con la corrupción administrativa y fiscal generó un clima propicio para asociarlo con la corrupción política. A pesar de tratarse de fenómenos diferentes, es evidente que quienes intercambian los bienes deben darle un tratamiento deferencial

\footnotetext{
${ }^{131}$ Ver Roll, “E1 clientelismo”, 115.

${ }^{132}$ Comparar García Villegas y Revelo Rebolledo, Estado, 31.
} 
a las reglas en cada caso, originando una frontera entre lo legal y lo ilegal que crea la antesala para la corrupción política. ${ }^{133}$

Para quienes asocian el clientelismo con corrupción política, el fenómeno se convierte en el primer factor que vulnera las bases del sistema democrático y fragmenta la igualdad de los ciudadanos por favorecer privilegiadamente a unos pocos a partir de la repartición desproporcional e inequitativa del erario público. ${ }^{134}$ Sin embargo, para superar las dificultades analíticas, es necesario establecer los límites entre la corrupción y el clientelismo y evitar estas apresuradas asimilaciones. El clientelismo que se da desde las instituciones públicas se genera a partir de la manipulación de las estructuras formales para el beneficio de grupos o sectores particulares. Por el contrario, la corrupción implica una trasgresión directa de las normas. ${ }^{135}$ Estos presupuestos nos obligan a hacernos las siguientes preguntas: ¿Qué sucede cuando se crean leyes para prevenir formas particulares de hacer política? ¿Es acaso desde este instante en que el clientelismo deviene en corrupción?

El reto que tienen los nuevos estudios sobre clientelismo consiste en superar el grado de ambigüedad del concepto y esto implica, en gran medida, tratar de eliminar todas aquellas interpretaciones que tienden a asociarlo con todos los vicios del sistema político colombiano. Este es un objetivo difícil, pero además peligroso, tal como plantea Francisco Gutiérrez, la noción "apropiación privada de lo público" pareciera ser una categoría aún inexplorada que podría acercarnos aún más a la delimitación, tanto de la corrupción como del clientelismo. Sin embargo, todavía hacen falta trabajos

\footnotetext{
${ }^{133}$ Dávila Ladrón de Guevara, “Clientelismo, intermediación”, 69.

${ }^{134}$ Comparar Roll, “El clientelismo”, 115.

${ }^{135}$ Duarte, Educación, 9.
} 
comparados que nos ayuden a establecer relaciones de causalidad y operacionalización de los fenómenos. ${ }^{136}$

\subsection{Clientelismo como representación}

La constitución de 1991 buscaba la modernización de la política, la apertura democrática y la erradicación del clientelismo. ${ }^{137}$ No obstante, el fenómeno no desapareció con la reforma. La constatación de este hecho generó una revisión del clientelismo en los estudios posteriores a 1991. Desde entonces, la definición y uso del concepto se problematiza, anotando un laxo empleo del mismo como sinónimo de corrupción e ilegalidad. Emergen, por ende, preguntas sobre la naturaleza del fenómeno, sus continuidades y transformaciones.

Ante la trasformación del régimen, O'Donnell, sugiere asumir al clientelismo no como un aspecto que se ubica fuera de la institucionalidad, sino como una forma diferente de la misma u "otra institucionalidad" anclada a los procesos de construcción del Estado y al sistema democrático de cada país. ${ }^{138}$

Al clientelismo, también, se le ha considerado como el mecanismo que superó la violencia sectaria entre liberales y conservadores a partir del Frente Nacional. ${ }^{139}$ Los partidos se convirtieron

${ }^{136}$ Comparar Francisco Gutiérrez Sanín y Andrés Dávila Ladrón de Guevara, "Paleontólogos o politólogos: ¿Qué podemos decir hoy sobre los dinosaurios?”, Revista de Estudios Sociales, (2000): 45.

${ }^{137}$ Algunos de los mecanismos creados por la Constitución de 1991 que castigaban las prácticas de clientelismo electoral eran: la circunscripción nacional para senado, el tarjetón, la no acumulación de mandatos, la modificación del calendario electoral, la desaparición de las suplencias, la pérdida de la investidura, el remplazo de la inmunidad parlamentaria por fuero y aumento drástico de las incompatibilidades.

${ }^{138}$ Comparar Dávila Ladrón de Guevara, “Clientelismo, intermediación”, 65.

${ }^{139}$ Ibid., 67-68. 
en aliados, se puso fin a la violencia política y se facilitó la continuidad de la democracia formal y el del resto de instituciones políticas. ${ }^{140}$

Sin embargo, adicional a estos pequeños elementos que permiten entrever aspectos positivos del clientelismo, autores como Miguel García, Francisco Gutiérrez, Andrés Dávila y Rocío Rubio marcaron un precedente en la forma de abordar el fenómeno al encontrar que las reformas hechas en Bogotá originaron dinámicas en las cuales hay un proceso de negociación, entre clientelas e intermediarios, para tramitar demandas sociales ante el Estado, generando un proceso de participación ciudadana que no necesariamente es ajeno a la democracia.

${ }^{140}$ Comparar también Ricardo Peñaranda y Javier Guerrero (compiladores), De las armas a la política (Bogotá: TM Editores; IEPRI, 1999). 


\section{La emergencia del clientelismo como objeto visible del sistema político y la preeminencia de la visión negativa del fenómeno}

Este capítulo busca esgrimir la hipótesis de trabajo que emergió de la revisión del estado del arte de los estudios de clientelismo en Colombia: la presencia de un mayor número de estudios sobre clientelismo donde el fenómeno es abordado desde una postura preeminentemente negativa puede ser explicada a partir de la creación de un discurso anti-clientelista que se gestó en el seno de la clase política, a raíz de un conflicto por el poder entre un sector modernizante e industrial y otro tradicional.

Se observa que la crisis del bipartidismo fue, en parte, producto de tres efectos de desestabilización del sistema. En palabras textuales de Francisco Gutiérrez:

Hay tres efectos de desestabilización, todos ellos verificados. Primero, una ruptura muy profunda entre el personal político tradicional y las élites socioeconómicas, sobre todo aquellas cuya actividad principal y residencia se encuentra en las grandes ciudades. Segundo, desprestigio y rechazo de dos de las instituciones claves de la vida política, Congreso y partidos. Este desprestigio ha ido acompañado de acciones concretas en varias direcciones 
comenzando con el encarcelamiento de decenas de congresistas liberales. Tercero, desestructuración de los partidos, al darle un gran margen de maniobra (gracias a recursos ilícitos), a grupos regionales y locales en su relación con la dirección partidista. ${ }^{141}$

El efecto bola de nieve sirve de analogía para explicar lo sucedido con estos tres efectos desestabilizadores del sistema. En primer lugar, la ruptura del personal político desencadenó un discurso abiertamente anti-clientelista, que tildaba de corruptos y anti-modernistas a los opositores a la reforma de 1968 o a los miembros de la oposición. En segundo lugar, se desprestigió a los cuerpos colegiados. Finalmente, se desestructuraron los partidos tradicionales. Así, el clientelismo aparece como objeto visible del sistema político colombiano en medio de una pugna por el poder político. Por esta razón, el discurso anti-clientelista no era consecuente en la eliminación del fenómeno. Por el contrario, este fue utilizado como mecanismo para desprestigiar al oponente, sin querer decir con ello que los políticos notables no hicieran uso de mecanismos clientelistas para mantenimiento y reproducción de su poder.

Lo anterior permite observar que existen elementos contradictorios entre el discurso que se generó alrededor del fenómeno y las medidas adoptadas para combatirlo. Las reformas institucionales que pretendían dar muerte al clientelismo sólo produjeron nuevos fenómenos aún más difíciles de combatir y unas dosis duplicadas de clientelismo. De esta manera, es posible pensar que la trasformación del fenómeno y la mezcla con otros problemas más complejos puede tener una profunda relación con la presencia

${ }^{141}$ Ver Gutiérrez Sanín y Dávila Ladrón de Guevara, "Paleontólogos”, 42. 
del narcotráfico y los grupos al margen de la ley en la política nacional. ${ }^{142}$

\title{
7.1. Propagación del clientelismo y del discurso anti-clientelista
}

Jaime Arocha traduce una cita de un experto en sistemas en la cual explica lo que sucede cuando se implementan medidas para modificar un sistema sin saber a ciencia cierta los posibles efectos: ${ }^{143}$

\begin{abstract}
Machetear es [...] "disminuir irregularidades sin habilidad o propósito definido"; [...] cuando un sistema construido de esta forma comienza a crecer, se hace más y más inestable. Si uno de sus subsistemas falla de una manera imprevista, es posible remediarlo hasta que desaparezca el problema. Sin embargo, como no hay una teoría general del funcionamiento de todo el [conjunto], éste no pasa a ser un agregado caótico de subsistemas, cuya influencia en
\end{abstract}

\footnotetext{
${ }^{142}$ Comparar Jaramillo, Clientelismo y poder: relectura, 19.

${ }^{143}$ Ver Joseph Weizenbaujm, Computer Power and Human Reason: From Judgement to Calculation (San Francisco: Freeman, 1976), 119. "To hack is, according to the dictionary, 'to cut irregularly, without skill or definite purpose; to mangle by or as if by repeated strokes of a cutting instrument [...]' Programming systems [...] just as houses, cities, systems of dams, and national economic policies can be similarly hacked together. As a system so constructed begins to get large, however, it also becomes increasingly unstable. When one of its subfunctions fails in an unanticipated way, it may be patched until the manifest trouble disappears. But since there is no general theory of the whole system, the system itself can only be a more or less chaotic aggregate of subsystems whose influence on one another's behavior is discoverable only piecemeal and by experiment. The hacker spends part of his time at the console piling new subsystems onto the structure he has already built $[. .$.$] and$ the rest of his time in attempts to account for the way in which substructures already in place misbehave [...] The act of modifying the then existing program invariably causes some of its substructures to collapse; they constitute, after all, an amorphous collection of processes whose interactions with one another are virtually fortuitous".
} 
la conducta mutua solo puede descubrirse fragmentariamente, por ensayo y error. El machetero gasta la mayoría de su tiempo [...] apilando nuevos subsistemas [correctivos], sobre una estructura ya establecida [...] [Para luego tratar] de explicar por qué esos subsistemas no operan adecuadamente [...] Las modificaciones del programa original indefectiblemente ocasionan el colapso de algunas subestructuras, debido a que al fin y al cabo éstas no son más que una aglomeración amorfa de procesos cuyas interacciones son virtualmente fortuitas. ${ }^{144}$

Arocha hace una crítica a las reformas de los años ochenta al señalar que las mismas institucionalizan elementos propios del clientelismo de tal manera que antes de darle muerte, se generan fenómenos aún más complejos.

No es complicado realizar un inventario de los "subprogramas correctivos" que quienes sustentan el poder han "macheteado" en 1979 desde sus "concolas" [consolas] de control político. Las reformas constitucional y de la justicia; el proyecto de estatuto indígena y la propuesta de reforma universitaria, entre otros, contienen elementos que institucionalizan e "involucran"las relaciones de clientela, fuera del ámbito político. Sin embargo, es dudoso su potencial estabilizador. Las declaraciones recientes de figuras políticas como el Dr. Echandía parecerían indicar que los "subprogramas macheteados" pueden llegar a erosionar el modelo que pretenden sustentar. ${ }^{145}$

${ }^{144}$ Ver Arocha Rodríguez, "Clientelismo”, 64.

${ }^{145}$ Ibid., 64. 
Por otro lado, David Roll afirma que el clientelismo moderno, tal como es conocido hoy día, si bien tuvo alguna presencia durante el Frente Nacional, sólo logró consolidarse completamente durante la etapa final del mismo; es decir, cuando más fue combatido. Según explica el autor, desde 1970 las élites políticas presentaron la necesidad, que con el paso de los gobiernos se fue haciendo progresiva, de utilizar mecanismos clientelistas que articularan el poder regional para lograr el triunfo de las elecciones. ${ }^{146}$

La metástasis del clientelismo a lo largo y a lo ancho del sistema político colombiano no tardó en elevar los costos de mantenimiento, el sostén y la reproducción de las clientelas. No en vano, los auxilios parlamentarios se convirtieron en fondos de financiación de las campañas políticas, que elevaron los costos de las mismas y limitaron la entrada de nuevos líderes a la arena política. ${ }^{147} \mathrm{Tal}$ aumento en los costos implicó acudir a fuentes de financiación privadas ilícitas o no. ${ }^{148} \mathrm{La}$ entrada de dineros ilegales al sistema político pronto produjo la injerencia de actores al margen de la ley en las decisiones tomadas por el mismo Estado. Andrés Dávila no podría decirlo mejor: "[...] el clientelismo, durante un buen tiempo, le generó al régimen político colombiano la legitimidad suficiente para reproducirse y subsistir; pero, evidentemente, también generó algunas condiciones de ilegitimidad en la medida en que sectores de la población ya no se sentían parte del sistema político y empezaban a cuestionar la institucionalidad vigente". ${ }^{149}$

\footnotetext{
${ }^{146}$ Ver Roll, “E1 clientelismo”, 117-118.

${ }^{147}$ Comparar Dávila Ladrón de Guevara, "Clientelismo, intermediación”, 68.

${ }^{148}$ Comparar Jaramillo, Clientelismo y poder: relectura, 19.

${ }^{149}$ Ver Dávila Ladrón de Guevara, “Clientelismo, intermediación”, 68.
} 
En efecto, las clientelas fueron las formas de vinculación de los ciudadanos al Estado. Sin embargo, la reforma de 1968, junto con la crisis de representatividad que ya venían sufriendo los partidos, generó una situación sostenida de corrupción administrativa tanto por la apropiación de bienes públicos con fines privados como por la injerencia de dineros privados ilegales en el sector público. Con todo ello, el clientelismo devino en corrupción, y la forma tradicionalmente adoptada para hacer política fue satanizada, penalizada y, por supuesto, considerada como contrapuesta al paradigma reinante: el democrático.

Para Fernán González, el debate que inició el ex presidente Lleras Restrepo en contra del clientelismo se enmarcó dentro de un proyecto de modernización de la vida política mucho más amplio, que se sustentaba en la implantación del modelo de sustitución de importaciones y, por ende, en el respaldo a los intereses del sector industrial. Sin embargo, se complementaba con un modelo de democracia formal tipo burgués que de cualquier forma implicaba el aumento de la concentración del poder en manos de los poderosos sobre la imposibilidad de injerencia de los más débiles. El discurso anti clientelista sostenido por el sector "modernizante" en Colombia, hasta este momento, no contempló la implementación de una democracia en el sentido substancial. El ex presidente no calculó que el clientelismo es imposible de superar sin ciertas bases mínimas de igualdad social y económica. ${ }^{150}$

${ }^{150}$ Comparar González, "Clientelismo”, 71. 


\section{Conclusiones}

El clientelismo en Colombia representa una preocupación nada despreciable ni en términos de cantidad, ni menos en términos teóricos para el mundo académico. Desde que el fenómeno se posicionó como problema visible del sistema político colombiano, en 1974, el análisis del problema ha sido constante y sostenido. Son de subrayar tres momentos importantes en la producción sobre clientelismo: en 1973, momento de su aparición; en 1980, momento en el que se observa una explosión de estudios de caso regionales; y en el año 2000, cuando hay un incremento en el número de publicaciones con un enfoque predominantemente neo institucional.

Dentro de los primeros estudios sobre el fenómeno en Colombia se encuentran los publicados por el Cinep en 1974, liderados por Miranda Ontaneda, y la tesis de doctorado de Steffen Walter Schmidt en 1973. Los postulados tanto de Miranda Ontaneda, como de otros autores de países europeos, permiten entrever que el desarrollo de los estudios en Colombia fue paralelo al de otros estudios que tenían lugar en países de Europa y en Estados Unidos, a propósito del tema.

Los dos primeros enfoques empleados para la comprensión del fenómeno fueron el funcionalista, más frecuentemente utilizado en el exterior, y el marxista, insumo fundamental para el desarrollo de enfoques posteriores, dentro de los cuales se pueden enlistar: el institucionalista, el estructural-funcionalista y el socioantropológico. 
En Colombia, en la década de los años setenta los dos enfoques predominantes fueron el funcionalista y el marxista. A pesar de que el enfoque funcionalista no fue el marco predilecto de los autores nacionales, se observa que este sí fue el punto de partida de los estudios inscritos en el enfoque marxista. En la década de los ochenta, el enfoque funcionalista desapareció del panorama, pero en su remplazo nacieron otros enfoques como el socio antropológico y el estructural-funcionalista. Por otro lado, los viejos postulados del institucionalismo, adaptados a las nuevas realidades, se empezaron a volver cada vez más frecuentes. Para la década de los noventa, los estudios marxistas exhibieron una frecuencia menor y, en cambio, el enfoque institucionalista se configuró como el marco conceptual predominante. Por lo anterior, se concluye que una ruptura en el abordaje del fenómeno en Colombia fue la utilización de los dos primeros enfoques a saber, el marxista y el funcionalista. Y como continuidad, se identifica la cada vez más frecuente publicación de estudios inscritos en la perspectiva institucionalista. Finalmente, durante las últimas dos décadas, los enfoques más recurrentes han sido: el institucionalista, el estructural-funcionalista y el socio antropológico.

Es claro que la década de los noventa exhibió un viraje en la forma de aproximación al clientelismo político. La obra de Francisco Leal y Andrés Dávila, junto con las de Francisco Gutiérrez Sanín, Miguel García y Rocío Rubio, empezaron a comprender al clientelismo tanto como fenómeno funcional al sistema político, como forma de hacer política compatible con mecanismos democráticos.

En un recorrido por los enfoques utilizados por los autores que han trabajado el problema del clientelismo en Colombia, se encuentra que la transformación de los paradigmas ha conducido a replantear las formas de aproximación al clientelismo: se 
presentó un desplazamiento de las ideas sobre desarrollo y capitalismo hacia un análisis de clase y el estudio de las instituciones formales. Actualmente, el clientelismo es asumido como un universo complejo, que puede sufrir trasformaciones a partir de las reformas al régimen. Las nuevas aproximaciones se caracterizan por posturas más comprensivas del fenómeno, donde la dimensión de la cultura y el comportamiento político adquieren un papel fundamental en los análisis.

Los autores que han contribuido al estudio del clientelismo político han identificado en sus obras tres tipologías de clientelismo alrededor de las cuales existe un grado considerado de consenso. Estas tres tipologías se distinguen por presentar ciertas características y por ser predominantes en periodos históricos determinados. La primera tipología, el clientelismo tradicional, marcó el periodo del siglo XIx hasta mediados del siglo Xx, se caracterizó por el intercambio de bienes, más que todo de procedencia priva$\mathrm{da}$, entre patrones, caciques o gamonales y sus respectivos clientes. Muchos de los autores que estudiaron esta tipología generaron relaciones entre este modelo de clientelismo e instituciones coloniales tales como la encomienda y la hacienda.

Por otro lado, la segunda tipología, conocida como clientelismo moderno, marcó todo el periodo seguido al establecimiento del Frente Nacional. Este es atribuido a las transformaciones sociales, económicas y políticas de la época. Su principal rasgo fue el intercambio de bienes y servicios más que todo de naturaleza pública, entre un patrón supremo (el Estado), un intermediario (los políticos, más que todo procedentes de cualquiera de los dos partidos tradicionales) y los clientes (la ciudadanía en general).

La tercera categoría es denominada por algunos autores como clientelismo de mercado. Vale la pena aclarar que esta última tipología aún es una hipótesis que requiere comprobación; a pesar 
de que un buen número de autores ya la reconocen y la dan por cierta. El clientelismo de mercado, hasta ahora, es un fenómeno observable en la ciudad de Bogotá. Lo anterior debido a las reformas en materia administrativa que sufrió la ciudad post Constitución de 1991 y a partir del estatuto orgánico. Concretamente, se caracteriza por contar con líderes de alcance local-lo que permite una competencia entre los mismos por la captación de votos- $y$, por ende, garantizar la capacidad de negociación por parte de las clientelas. La naturaleza de los bienes intercambiados en el clientelismo de mercado es tanto pública como privada y los capitales no siempre son lícitos.

Es cierto que cada una de estas categorías obedece a unas transformaciones que marcaron ciertos periodos de la historia colombiana. Sin embargo, Fernán González señala que las categorías de clientelismo tradicional y moderno también pueden obedecer a lógicas espaciales de la organización del poder político.

La hipótesis desarrollada por el presente estado del arte sostuvo que el hecho de que el clientelismo se posicionara en Colombia a partir de 1974, tanto en la agenda académica como política como un elemento problemático y negativo del sistema político colombiano, tuvo que ver con las transformaciones de la vida política colombiana de la época. Como sustento de lo anterior, se mostró que previamente a la década de los setenta, los mecanismos dispuestos por el ejecutivo para lograr la aprobación, por parte del Congreso, de la reforma constitucional de 1968, puso en evidencia: por un lado, la división de las élites políticas entre un sector industrial y "tecnócrata” y otro sector arraigado a las dinámicas regionales y, por tanto, tradicionales. Fue en este clima político que el debate sobre el clientelismo llegó a Colombia por medio de académicos como Néstor Miranda Ontaneda y el Cinep. Esta coincidencia sirvió para que el ex presidente Carlos Lleras 
Restrepo se abanderara del discurso modernizador y se gestara un discurso anti-clientelista en contra de los líderes políticos tradicionales. Este discurso logró influenciar la opinión de los medios de comunicación, las reformas institucionales emprendidas y un gran número de estudios sobre clientelismo, haciendo de la visión negativa la aproximación hegemónica al clientelismo político.

Las dos reformas más importantes de los últimos lustros (la de 1968 y la proclamación de la nueva Carta Constitucional en 1991) tuvieron como objetivo la modernización del país, en un primer momento, y luego la puesta en marcha de una democracia más participativa. Ambas reformas trataron de romper con prácticas clientelistas. Sin embargo, los diseños institucionales antes de eliminar el clientelismo han incentivado su trasformación, adaptabilidad y afianzamiento. Lo anterior, en paralelo con procesos de promoción de la participación ciudadana y del voto de opinión, más programático y menos anclado a dádivas. Esta coexistencia de elementos antes considerados como contradictorios ha generado que los investigadores exploren nuevas formas de aproximación al fenómeno, estableciendo relaciones entre mecanismos de representación y de formación de ciudadanía con el clientelismo, a partir de redes clientelares de corto alcance que tengan acceso a núcleos descentralizados de poder.

Este estudio permite sugerir que el clientelismo se comporta dentro del sistema político colombiano como un fenómeno que ha logrado irrigar todos los recodos de la vida pública. Se trata de una suerte de rayo de luz que a partir del efecto de la refracción permite entrever todos los posibles matices de la vida política actual. Es así como su estudio permite vincular su proceso de intervención (incluyendo todas las reformas institucionales e intentos para eliminarlo) con otros fenómenos posteriores como el de la emergencia de grupos armados al margen de la ley y 
emergencia de economías ilegales. El camino en dirección a mecanismos políticos más inclusivos, trasparentes, que permitan la creación de un nuevo imaginario de lo público, requieren estudios de caso comparados que permitan dar un tratamiento diferencial, objetivo y claro sobre el problema del clientelismo en Colombia. 


\section{Bibliografía}

Alzate Cardona, Gilberto. Concentración de poder, violencia, clientelismo y democracia participativa en Colombia. Bogotá: Pontificia Universidad Javeriana, 1995.

Archer, Ronald P. The Transition from Traditional to Broker Clientelism in Colombia:Political Stability and Social Unrest. Notre Dame, Indiana: Kellogg Institute for International Studies, 1990.

Cepeda Van Houten, Álvaro. Neopentecostalismo y política. El caso colombiano. Cali: Universidad de San Buenaventura, 2010.

Díaz Uribe, Eduardo. Elclientelismo en Colombia: Un estudio exploratorio. Bogotá: Áncora Editores, 1986.

Duarte, Jesús. Educación pública y clientelismo en Colombia. Medellín: Universidad de Antioquia, 2003.

Echavarría Córdoba, Jaime y Julio C. Hálaby Córdoba. Sociología politica de comicios yclientelismo. Chocó: Universidad Tecnológica del Chocó, 1988.

Echeverri Uruburu, Álvaro. Élites, clientelismo y burocracia estatal, 19601990. Bogotá: Universidad Autónoma de Colombia, 1993.

Escobar, Cristina. Clientelism Movilization and Citizenship: Peasant Politics in Sucre, Colombia. Michigan: UMI, Ann Arbor, 1998.

García Sánchez, Miguel. ¿Ciudadanía avergonzada? Democracia local y construcción de ciudadanía en Bogotá. Bogotá: Universidad de los Andes y Universidad Nacional de Colombia, 2003.

García Villegas, Mauricio y Javier Eduardo Revelo Rebolledo. Estado alterado. Clientelismo, mafias y debilidad institucional en 
Colombia. Bogotá: Centro de estudios de Derecho, Justicia y Sociedad, 2010.

González Alcantud, José A. El clientelismo politico. Perspectiva socioantropológica. Barcelona: Anthropos Ediorial, 1997.

González, Fernán E. Para leer la politca: Ensayos de historia politica colombiana. Bogotá: Cinep, 1997.

Guillén Martínez, Fernando. El poder politico en Colombia. Bogotá: Punta de lanza, 1979.

Hartlyn, Jonathan. La politica del régimen de coalición. Bogotá: Tercer Mundo y Universidad de los Andes, 1993.

Jaramillo, Nicolás. Clientelismo y poder: relectura crítica de algunas reflexiones hechas sobre el clientelismo en Colombia. Bogotá: Universidad Nacional de Colombia, Facultad de Derecho, Ciencias Políticas y Sociales, 2005.

Leal Buitrago, Francisco y Andrés Dávila Ladrón de Guevara. Clientelismo, el sistema político y su expresion regional. Bogotá: Tercer Mundo Editores, 1991.

LeGrand, Catherine. Colonización y Protesta campesina en Colombia, 1850-1950. Bogotá: Universidad Nacional de Colombia, 1988.

León Monsalvo, Alfredo Antonio. Penumbras y demonios en la politica colombiana: un análisis sobre el clientelismo. Bogotá: Ediciones Desde abajo, 2011.

Losada Lora, Rodrigo. Clientelismo y elecciones: tres modelos explicativos del comportamiento electoral colombiano. Bogotá: Pontificia Universidad Javeriana, 1984.

Losada Lora, Rodrigo y Andrés Casas Casas. Enfoques para el análisis politico: historia, epistemología y perspectivas de la ciencia politica. Bogotá: Pontificia Universidad Javeriana, Facultad de Ciencias Políticas y Relaciones Internacionales, 2008. 
Martz, John D. The Politics of Clientelism: Democracy \& the State in Colombia. New Brunswick, New Jersey: Transaction Publishers, 1997.

Miranda Ontaneda, Néstor. Clientelismo y dominio de clase. Bogotá: Cinep, 1977.

Moreno Arteaga, Darío. El sistema politico del clientelismo en Popayán, 1930-1940. Bogotá: Ministerio de Cultura, 2002.

Peñaranda, Ricardo y Javier Guerrero (compiladores). De las armas a la política. Bogotá: TM Editores; IEPRI, 1999.

Ramírez, María Clemencia. Entre el Estado y la guerrilla: identidad y ciudadania en el movimiento de los campesinos cocaleros en Putumayo. Bogotá: Instituto Colombiano de Antropología e Historia-Colciencias, 2001.

Reyes, Alejandro. Latifundio y poder politico: la hacienda ganadera en Sucre. Bogotá: Cinep, 1978.

Roll, David Alberto. Rojo difuso y azul pálido. Bogotá: Universidad Nacional de Colombia, 2002.

Roll,David Alberto. Inestabilidad y continuismo en la dinámica del cambio politico en Colombia:perspectiva de la reforma politica en Colombia desde 1930 hasta 1991. Bogotá: ICFes, 1999.

Rubio Serrano, Rocío. No hay paraísos sino los perdidos: Historia de una red clientelista en Bogotá. Bogotá: Universidad Nacional de Colombia, 2003.

Sudarsky,John. Clientelismo y Desarrollo Social. Bogotá:Tercer Mundo Editores, 1988.

Valenzuela Ramírez, Jorge. Producción arrocera y clientelismo. Bogotá: Cinep, 1978.

Vasco, Eloísa. Clientelismo y minifundio: bases socio-económicas del poder politico en un municipio minifundista. Bogotá: Cinep, 1978.

Weizenbaujm, Joseph. Computer Power and Human Reason: From Judgement to Calculation. San Francisco: Freeman, 1976. 


\section{Capítulos o artículos en libro}

Dávila Ladrón de Guevara, Andrés. “Clientelismo y elección popular de alcaldes: dilemas y 'sinsalidas' en la conformación de un nuevo sistema político". En Descentralización y corrupción, coords. Fernando Rojas, Andrés Dávila Ladrón de Guevara, Jorge M. Eastman Robledo y Jesús A. Bejarano, 49-68. Bogotá: Milenio \& Fescol, 1996.

Dávila Ladrón de Guevara, Andrés y Natalia Delgado Varela. "La metamorfosis del sistema político colombiano: ¿Clientelismo de mercado o nueva forma de intermediación?". En Degradación o cambio: evolución del sistema politico colombiano, compilado por Francisco Gutiérrez Sanín, 319-356. Bogotá: Editorial Norma, 2002.

García Sánchez, Miguel. "La política bogotana, un espacio de recomposición (1982-2001)”. En Degradación ocambio:evolución del sistema político colombiano, compilado por Francisco Gutiérrez Sanín, 183-220. Bogotá: Editorial Norma, 2002.

Gutiérrez Sanín, Francisco. “Clientelismo y sus enredos". En La ciudad representada:politica y conflicto en Bogotá, 55-120. Bogotá: TM Editores, 1998.

Gutiérrez Sanín, Francisco. "Historia de democratización anómala: el partido Liberal en el sistema político colombiano desde el Frente Nacional hasta hoy". En Degradación o cambio: evolución del sistema político colombiano, compilado por Francisco Gutiérrez Sanín, 25-78. Bogotá: Editorial Norma, 2002.

Hernández Humberto,Luis. “Colombia: Mafia y sistema político”. En $\dot{i}$ Estado y cultura mafiosa en Colombia?, coordinado por Óscar Mejía Quintana, 127-147. Bogotá: Universidad Nacional de Colombia, Facultad de Derecho, Ciencias Políticas y Sociales, 
Instituto Unidad de Investigaciones Jurídico-Sociales Gerardo Molina, 2010.

Morales Benítez, Otto. “Clientelismo y Corrupción”. En Carlos Lleras Restrepo, compilado por Otto Morales Benítez,113-172. Santafé de Bogotá: Universidad Central, 1999.

Palacios, Marco. "Presencia y ausencia de populismo: para un contrapunteo colombo-venezolano”. En Populistas, mandarines y violencias. Luchas por el poder, 45-81. Bogotá: Editorial Planeta Colombiano, 2001.

Pecaut, Daniel. "Populismo imposible y Violencia: El caso colombiano". En Guerra contra la sociedad, 53- 86. Bogotá: Editorial Planeta Colombiano, 2001.

Pizarro Leongómez, Eduardo. "La atomización partidista en Colombia: el fenómeno de las micro-empresas electorales". En Degradación o cambio: evolución del sistema político colombiano, compilado por Francisco Gutiérrez Sanín,357-401. Bogotá: Editorial Norma, 2002.

Sills David L. y otros. "Análisis Funcional”. En Enciclopedia Internacional de las Ciencias Sociales, (Madrid: Editorial Aguilar, vol. I, 1974).pp. 299-317.Madrid:Editorial Aguilar, vol.I, 1974. Wills Obregón,María Emma y María Milagros Rivera Bonza."Poder, familia y clientelismos en Montería, Córdoba (1950-2008): Visibilización y ascenso de las mujeres en contextos totalitarios". En A la sombra de la guerra: ilegalidad y nuevos órdenes regionales en Colombia, 97-164. Bogotá: Universidad de los Andes, Facultad de Ciencias Sociales, Centro de Estudios Socioculturales, 2009. 


\section{Artículos en publicaciones periódicas académicas}

Aguirre González, Guillermo. "Clientelismo, caciquismo y caudillismo, expresiones de una práctica política”. Revista Sociología (2004): 100-106.

Alviar Nieto, Mario. “Clientelismo y participación política: el caso de la juventud liberal”. Enfoques colombianos (1980): 107-127.

Arocha Rodríguez,Jaime. “Clientelismo, gasteo y violencia”. Enfoques colombianos 14 (1980): 47-65.

Betancourt, Car. "Clientelismo y asimetría de agendas en la descentralización colombiana”. Revista de la Contraloría general de la repuiblica 60 (2000): 82-91.

Dávila Ladrón de Guevara, Andrés y Miguel García Sanchez. "Control político y control ciudadano en Bogotá”. Servicio Civily mecanismos de control (2000).

Dávila Ladrón de Guevara, Andrés. “Clientelismo, intermediación y representación política en Colombia: ¿Qué ha pasado en los noventa?”. Estudios Politicos (1999): 62-78.

Deas, Malcolm. "Algunas notas sobre el caciquismo en Colombia". Revista de Occidente tomo XLIII (1973): 118-140.

Díaz, Fernando. "Dominacion, clientelismo y desarrollo social en el Bajo Sinú”. Revista Universidad de Córdoba (1994): 21-26.

García Duarte, Ricardo."El mercado político y la lógica de la clientela". Revista Foro (1994): 17-25.

Escalante, Fernando. "Clientelismo y ciudadanía en México: apuntes sobre la conceptualización de las formas de acción política”. Análisis Politico (1995): 31-41.

Escobar, Cristina. "Clientelismo y ciudadanía: los límites de las reformas democráticas en el departamento de Sucre”. Análisis Político (2002): 36-54. 
González, Fernán E. “Clientelismo y administración pública”. Enfoques colombianos (1980): 67-106.

González, Fernán E. “¿Colapso parcial o presencia diferenciada del Estado en Colombia? Una mirada desde la historia”. Colombia Internacional (2003): 124-158.

González, Fernán E. "Aportes al diálogo entre historia y ciencia política. Una contribución desde la experiencia investigativa en el Cinep". Historia Critica (2004): 23-38.

González, Fernán E. "Apróximación a la configuración política de Colombia”. Controversia 2 (1989): 19-72.

Gutiérrez Sanín, Francisco y Andrés Dávila Ladrón de Guevara."Paleontólogos o politólogos: ¿Qué podemos decir hoy sobre los dinosaurios?". Revista de Estudios Sociales (2000): 39-49.

Leal Buitrago, Francisco. "El sistema político del clientelismo”. Análisis Politico (2003): 63-140.

LeGrand, Catherine C. "Perspectives for the Historical Study of $\mathrm{Ru}-$ ral Politics and the Colombian Case: An Overview". Latin American Research Review 12 (1977): 7-36.

Medina, Medófilo. "Clientelismo: el sistema político y su expresión regional". Análisis Político (1991): 95-99.

Mendoza M., Adaulfo Enrique. "Estado, clientelismo y sociedad: una mirada desde la función política de la Educación”. Cuestiones IV (2007): 97-108.

Meneses, Lucía Eugenia. "La política Nasa y el clientelismo en el municipio de Paéz, Cauca”. Revista colombiana de Antropología e Historia 38 (2002): 105-130.

Miranda Ontaneda, Néstor. "El poder político en Colombia”. Enfoques colombianos (1980): 7-46.

Miranda Talero, Alfonso. "Del manzanillismo al clientelismo presupuestal”. Areopago (1987): 24-25. 
Pizano Rojas, Lariza. "Caudillismo y clientelismo: expresiones de una misma lógica. El fracaso del modelo liberal de Latinoamérica”. Revista de Estudios Sociales (2001): 75-83.

Rivera Romero, Federico. "El neoinstitucionalismo y la investigación en las ciencias sociales". Revista Centroamericana de Administración Pública-ICAP (2013): 101-128

Roll, David Alberto. "El clientelismo: corrupción a tres bandas". Sindéresis (2000): 114-128.

Schmidt, Steffen W."Bureaucrats as Modernizing Brokers? Clientelism in Colombia”. Comparative Politics 6 (1974): 425-450.

Uprimny, Rodrigo. "Legitimidad, clientelismo y política en Colombia: Un ensayo de interpretación”. Cuadernos de Economia x (1989): 113-164.

\section{Artículos en publicaciones periódicas no académicas}

Losada, Rodrigo. "Reformas regresivas: las reformas electorales propuestas por el gobierno solo favorecen a los caciques y al clientelismo". Dinero, septiembre, 1996.

\section{Otros documentos}

Fonseca Galvis, Ángela María. "E1 elefante en la Caja Agraria”. Tesis de maestría, Universidad de los Andes, Bogotá, 2008.

Gallego Durán, Jorge Andrés y Rafael Raciborsky. Clientelism, Income, Inequality, and Social Preferences: An Evolutionary Approach to Poverty Traps.Informe no publicado. Consultado agosto 29, 2014. http://growth-institutions.ec.unipi.it/pages/InstitutionI/clientelism.pdf

González Hernández, Carlos José. "La cofinanciación en Colombia: una empresa más del clientelismo político". Tesis de pregrado, Universidad de lo Andes, Bogotá, 2001. 
Guevara Salamanca, Juan David. "La democracia participativa como instrumento de dominación de la esfera pública. Una mirada crítica a la realidad política colombiana a partir de la constitución de 1991". Trabajo de grado, Universidad del Rosario, Bogotá, 2009.

Jaramillo G., Nicolás J. "Clientelismo y Poder. Cambios en las relaciones clientelistas en Colombia (1960-1990)”. Tesis de pregrado, Universidad Nacional, Bogotá, 2003.

Múnera Rojas, Betty Paola. "Clientelismo mafioso: estudio de caso de una red clientelista para elecciones de alcalde". Tesis de pregrado, Universidad de los Andes, Bogotá, 2006.

Ramírez Montenegro, Verónica. "Análisis de la participación en ejercicios de control ciudadano sobre la gestión pública estatal". Monografía de grado,Universidad del Rosario, Bogotá, 2009. Sandquist Restrepo, Erik. "Clientelismo, descentralización y Fondo de Cofinanciación”. Tesis de pregrado, Universidad de los Andes, Bogotá, 2001.

Santos Villagrán, Rafael José. "Bogotá: The Collapse of a Political Machine”. Cuadernillo no publicado, Universidad de los Andes, Facultad de Economía, Bogotá, 2007.

Schmidt, Steffen Walter. "Polítical Clientelism in Colombia". Tesis de doctorado, University Microfilms International,Londres, 1972.

Torres Bustamante, María Clara. El fenómeno del clientelismo político: Visión de los funcionalistas y de los marxistas. Consultado octubre 15, 2012. http://www.institut-gouvernance.org/es/ analyse/fiche-analyse-43.html.

Torres Preciado, Javier Fernando. "Vicio y virtud: el sistema político colombiano en el periodo 1848-1885”. Tesis de maestría, Universidad de los Andes, , Bogotá, 2008. 

Anexos 


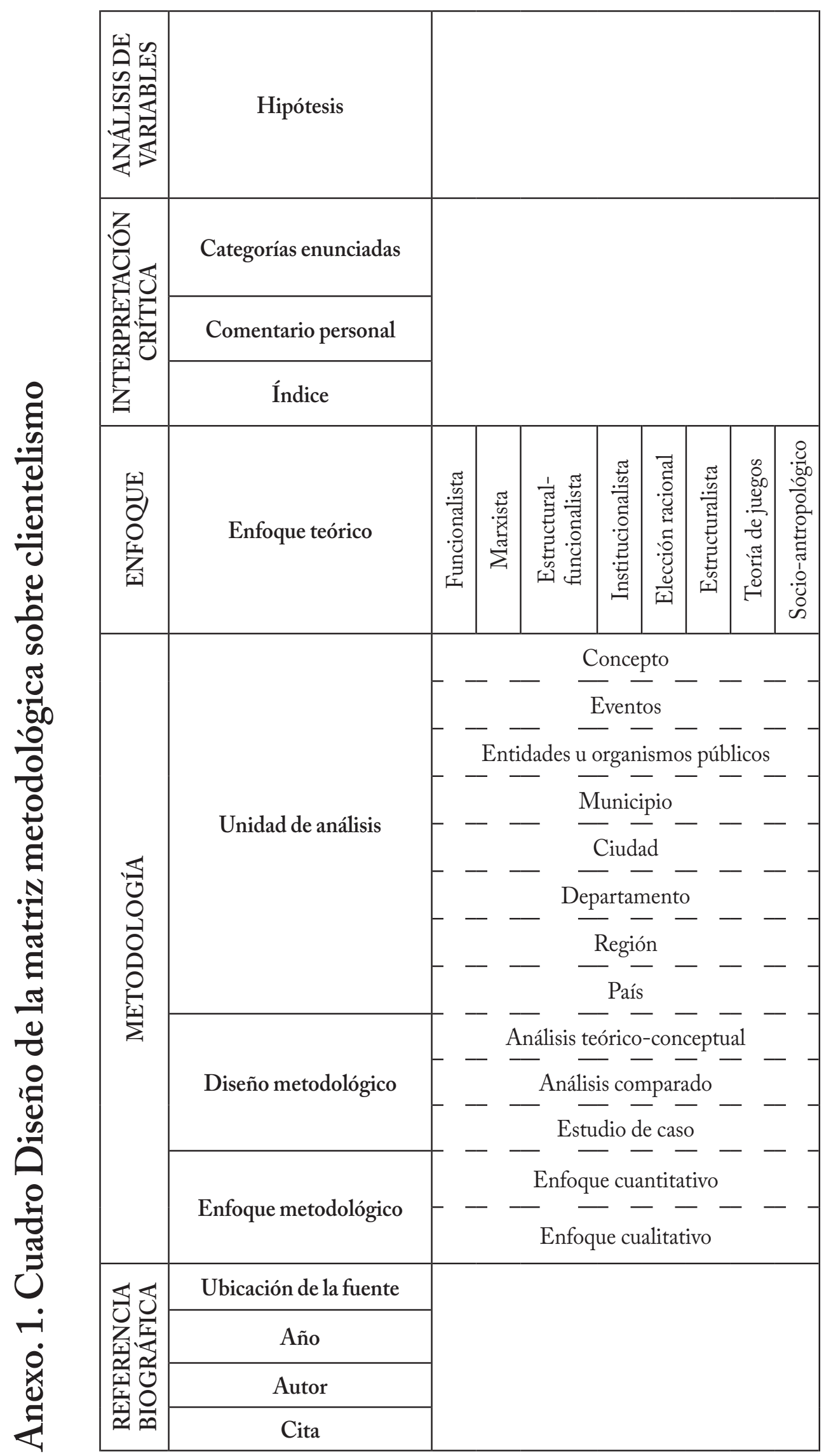




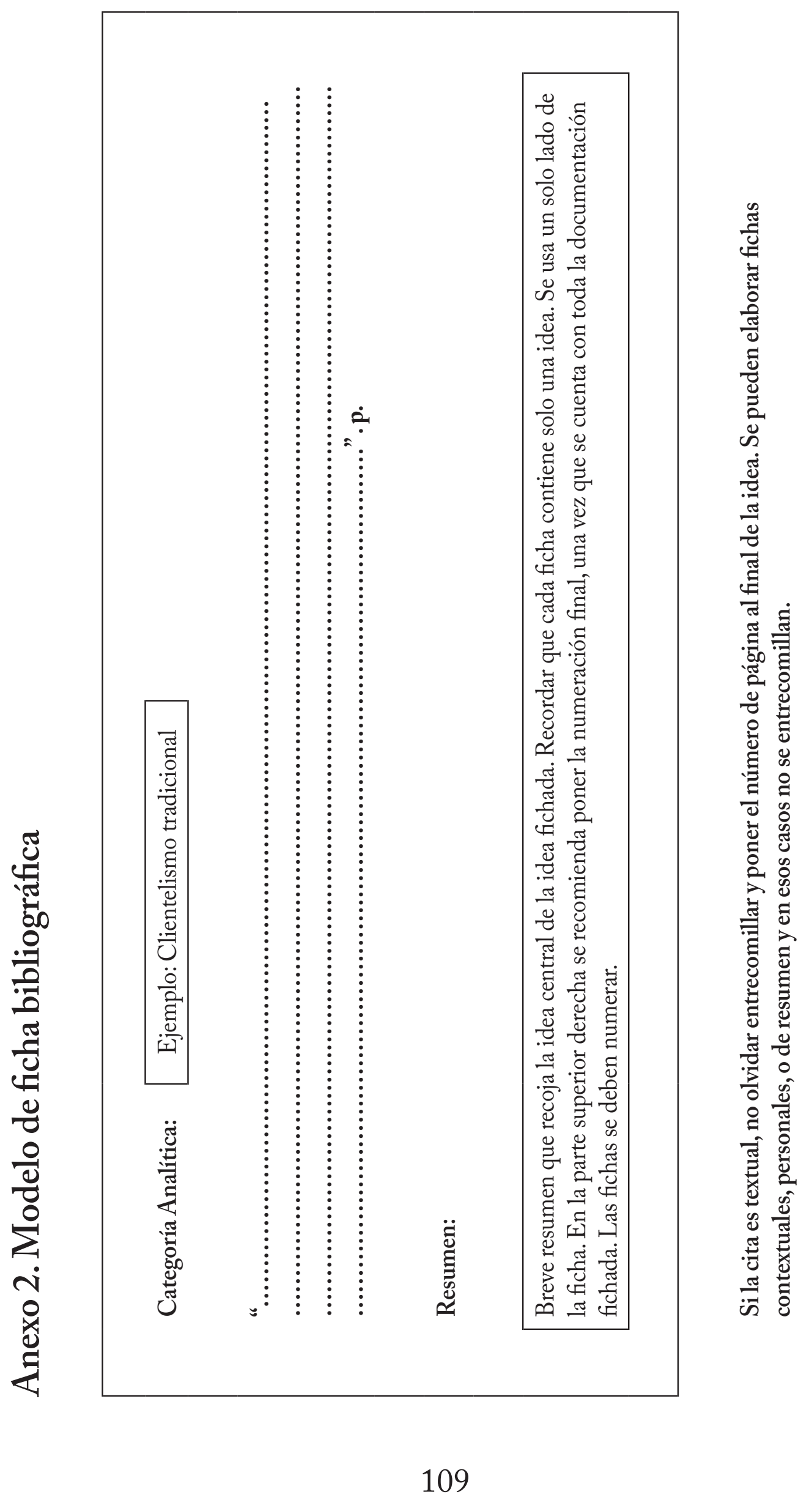




\section{Anexo 3. Producción de estudios sobre clientelismo en Colombia por décadas}

\begin{tabular}{|c|c|}
\hline Cita & $\begin{array}{l}\text { Schmidt, Steffen Walter. "Political Clientelism in Colombia". Tesis de doctorado. } \\
\text { Londres: University Microfilms International, } 1972\end{array}$ \\
\hline Año & 1972 \\
\hline $\begin{array}{r}\text { Enfoque } \\
\text { teórico } \\
\end{array}$ & Funcionalista \\
\hline $\begin{array}{r}\text { Categorías } \\
\text { enunciadas }\end{array}$ & Relaciones patron-intermediarios-cliente; Frente Nacional; bipartidismo; violencia. \\
\hline Hipótesis & $\begin{array}{l}\text { "Violence as a by-product of highly competitive politics appears to have cast } \\
\text { Colombian struggles for control of decisions making positions into a winner-take- } \\
\text { all framework. Patronage jobs and preferments in the use of public funds have been } \\
\text { the characteristic exchange for political loyalty. Thus political has been of great } \\
\text { interest both to the winning politician ant to his client supporters. } \\
\text { In the analysis of a small, highland community, Salado, one finds among } \\
\text { other things that the high level of political conflict has led to two significant } \\
\text { consequences. First, people relate politically more to others of their own party } \\
\text { because the violence was primarily between the two parties. This forms the basis for } \\
\text { rather small networks of people working through brokers to achieve personal and } \\
\text { family well being. } \\
\text { Second, Saladans keep opinions about important issues to themselves, } \\
\text { dichotomizing their articulation into what I have called "public" and "private" } \\
\text { responses. Finally three functionally distinct leadership types, community oriented, } \\
\text { particularistic and positional brokers are identified. } \\
\text { From the analysis we can conclude that intense political competition in Colombia } \\
\text { has led to the creation of strong clientelistic networks forming the infrastructure } \\
\text { of the political parties. Since } 1957 \text { the National Front coalition has reduced the } \\
\text { dependence of the parties on these networks and on voter turnout. Other groups, } \\
\text { notably Anapo, a new political party, have tried to gain access to the relatively } \\
\text { dormant polity. } \\
\text { Patron-broker-client relations as the dominant force responsible for the } \\
\text { instrumental and affective political loyalties of Colombians, has force the Liberal } \\
\text { and Conservative parties to remain at least modestly responsive to "public opinion" } \\
\text { and thus has avoided a complete isolation of the elite from the masses. It has given } \\
\text { the political system the characteristics of elasticity, moderate authoritarianism and a } \\
\text { very competitive, violent party system. One can tentatively conclude therefore that } \\
\text { an increased level of competitiveness between Liberals and Conservatives will renew } \\
\text { the relevance of clientelistic politics to the Colombian arties". (p. 2-3) }\end{array}$ \\
\hline $\begin{array}{l}\text { Observaciones } \\
\text { sobre la fuente }\end{array}$ & $\begin{array}{l}\text { El análisis parte del cuestionamiento sobre las posibles causas que explicaban la } \\
\text { ferviente participación de los colombianos en la política. Para el autor, era claro } \\
\text { que el sistema político colombiano estaba dado por la dinámica bipartidista. Sin } \\
\text { embargo, aspectos que principalmente habían sido tomados para dar razón de } \\
\text { dichas dinámicas, tales como los grupos de interés, las ideologías, el comportamiento } \\
\text { electoral, la lógica incondicional entre partidos (parties qua parties), no eran aspectos } \\
\text { suficientes para explicar la participación política colombiana. El autor identificó que } \\
\text { la participación estaba dada por unos incentivos desinteresados, pero más aún, por } \\
\text { una lógica instrumental que explicaba el reclutamiento de partidos y la intensidad } \\
\text { de la dinámica. Este marco es el que abre la discusión del clientelismo en Colombia, } \\
\text { su construcción teórica identifica } 4 \text { dimensiones del clientelismo a saber: 1. La } \\
\text { reciprocidad; 2. Relación cara a cara; } 3 \text {. Desigualdad; 4. Multidimensionalidad. }\end{array}$ \\
\hline
\end{tabular}




\begin{tabular}{|c|c|}
\hline Cita & $\begin{array}{l}\text { Dávila Ladrón de Guevara, Andrés. “Clientelismo y elección popular de alcaldes: } \\
\text { dilemas y 'sin salidas'en la conformación de un nuevo sistema político”. En } \\
\text { Descentralización y corrupción, editado por Fernando Rojas, Andrés Dávila Ladrón } \\
\text { de Guevara, Jorge M. Eastman Robledo y Jesús A. Bejarano, 49-68. Bogotá: Milenio } \\
\text { \& Fescol, 1996. }\end{array}$ \\
\hline Año & 1996 \\
\hline $\begin{array}{r}\text { Enfoque } \\
\text { teórico }\end{array}$ & Institucionalista \\
\hline $\begin{array}{r}\text { Categorías } \\
\text { enunciadas }\end{array}$ & $\begin{array}{l}\text { Elección popular de alcaldes; descentralización; Frente Nacional; clientelismo } \\
\text { moderno; corrupción; clientelismo armado. }\end{array}$ \\
\hline Hipótesis & $\begin{array}{l}\text { "A continuación se plantea una interpretación de la elección popular de alcaldes } \\
\text { y la descentralización como cambios en el régimen político que potencialmente } \\
\text { afectarían la lógica de funcionamiento del clientelismo pero cuyos efectos son } \\
\text { todavía inciertos [...] Antes de continuar, considero importante hacer dos } \\
\text { aclaraciones que explican el carácter hipotético, de reflexión inicial y de propuesta } \\
\text { de investigación de muchos de los planteamientos desarrollados. En primer lugar, } \\
\text { aunque es evidente que la descentralización y la elección popular de alcaldes han } \\
\text { modificado el proceso político, y la nueva Constitución y sus desarrollos legales } \\
\text { y normativos han profundizado este proceso, hay en juego relaciones conflictivas } \\
\text { y tendencias muy variadas que dificultan discernir claramente el rumbo de los } \\
\text { acontecimientos y las relaciones que finalmente predominarán entre los distintos } \\
\text { factores considerados. Y en segundo lugar, este carácter transicional y de cambio en } \\
\text { aspectos centrales de la vida política colombiana carece aún de suficientes análisis y } \\
\text { diagnósticos y evaluaciones sistemáticas o aproximaciones relativamente rigurosas, } \\
\text { desde el ángulo político, a cada uno de los fenómenos y mucho menos a sus } \\
\text { interrelaciones".(p.50) }\end{array}$ \\
\hline $\begin{array}{r}\text { Observaciones } \\
\text { sobre la fuente }\end{array}$ & $\begin{array}{l}\text { Este artículo se cuestiona por los efectos que tuvieron las relaciones clientelistas } \\
\text { en Colombia luego de la implementación de la elección popular de alcaldes en } \\
1988 \text { y la descentralización propuesta por la Constitución política de 1991. Ente } \\
\text { este, Dávila concluye que son claros los efectos que estas medidas de ingeniería } \\
\text { institucional han tenido. En primer lugar, afirma que los casos de corrupción abierta } \\
\text { puede ser un producto de la pérdida de poder a lo largo de la etapa de clientelismo } \\
\text { moderno; en segundo lugar, se abre la entrada a actores armados, como la guerrilla, } \\
\text { imprimiendo un nuevo matiz de "clientelismo armado"; el tercer efecto, recalca el } \\
\text { autor, concerniente a los líderes, facciones clientelares, coaliciones y movimientos, } \\
\text { debe seguir siendo investigado por cuanto no existe suficiente evidencia empírica de } \\
\text { tales transformaciones. Este artículo es importante en la medida en que hace énfasis } \\
\text { sobre un vacío de conocimiento en el área del clientelismo político en Colombia. }\end{array}$ \\
\hline
\end{tabular}

\begin{tabular}{r|l}
\hline Cita & $\begin{array}{l}\text { Schmidt, Steffen W. "Bureaucrats as Modernizing Brokers? Clientelism in } \\
\text { Colombia”. Comparative Politics 6, (1974): 425-450. }\end{array}$ \\
\hline Año & 1974 \\
\hline $\begin{array}{r}\text { Enfoque } \\
\text { teórico }\end{array}$ & Funcionalista \\
\hline $\begin{array}{r}\text { Categorías } \\
\text { enunciadas }\end{array}$ & $\begin{array}{l}\text { Burocracia moderna; relaciones patrón-intermediario- cliente; técnico- burócrata } \\
\text { moderno (intermediario). }\end{array}$ \\
\hline
\end{tabular}




\begin{tabular}{c|l}
\hline Hipótesis & [El autor sostiene que la modernización de la burocracia puede acarrear un cambio \\
en las características iniciales del intermediario político; sin embargo, estos nuevos \\
intermediarios nunca abandonan algunas características principales de las relaciones \\
clientelares. Los burócratas modernos pueden seguir siendo intermediarios \\
políticos, lo que implica una contradicción con el tipo ideal de burocracia de \\
Max Weber]: “En una burocracia 'tipo ideal', la racionalidad y la desmitificación \\
aumentan a medida que la burocracia se vuelve más sofisticada. Argumentaré, en \\
cambio, que no hay pruebas que indiquen que una burocracia técnicamente mejor \\
preparada no tiene que ser necesariamente: (a) funcional en el sentido específico \\
que el burócrata seguirá las órdenes del superior y no estará dispuesto a participar en \\
política en defensa de sus propios programas, ni (b) más impersonal. En este último \\
caso, el burócrata moderno es un individuo que de hecho puede ser caracterizado \\
como 'formalmente impersonal'; sin embargo, si su sistema social es aquel en el que \\
los vínculos clientelistas son buscados, puede ser obligado a establecer estos vínculos \\
por sí mismo con el fin de lograr los planes técnicos que desea. Una vez hecho esto, \\
existe la posibilidad de que ya no va a ser capaz de limitar su interacción con el \\
'distrito electoral'o 'clientes' para los aspectos de la ejecución del programa, ya que el \\
clientelismo tiende a convertirse en un proceso múltiple y complejo con condiciones \\
ilimitadas de interacción”. (p. 426)
\end{tabular}

\begin{tabular}{r|l}
\hline Cita & $\begin{array}{l}\text { LeGrand, Catherine C. "Perspectives for the Historical Study of Rural Politics and } \\
\text { the Colombian Case: An Overview". Latin American Research Review 12,(1977): } \\
7-36 .\end{array}$ \\
\hline Año & 1977 \\
\hline $\begin{array}{r}\text { Enfoque } \\
\text { teórico }\end{array}$ & Estructuralista \\
\hline $\begin{array}{r}\text { Categorías } \\
\text { enunciadas }\end{array}$ & $\begin{array}{l}\text { Política rural colombiana; campesinos y rebelión; interacción de la política } \\
\text { nacional y la local; relaciones patrón-cliente; regionalismo. }\end{array}$ \\
\hline
\end{tabular}




\begin{tabular}{|c|c|}
\hline Hipótesis & $\begin{array}{l}\text { La autora concluye que es necesario formular investigaciones empíricas centradas en } \\
\text { el ámbito sub-nacional, que retomen lo dicho en los campos de la motivación de la } \\
\text { agitación campesina; la interacción nacional y local; las relaciones patrón-cliente; y el } \\
\text { regionalismo: "To conclude, four mutually complementary research perspectives - } \\
\text { the structural motivations of peasant unrest, local-national interaction, patron-client } \\
\text { relations, and regionalism- have been explored in terms of the orientations they } \\
\text { espouse, the questions they raise, and the advantages they offer for the study of rural } \\
\text { politics in Latin America and elsewhere. It has been argued that research which } \\
\text { makes use of these perspectives should help to fill significant gaps in Colombian } \\
\text { agrarian and political history. This kind of investigation may shed light on such } \\
\text { fundamental issues in Colombian historiography as rural-urban ties and power } \\
\text { relations, the origins of La Violencia, and the socioeconomic bases and evolution of } \\
\text { the party system over time. A number of scholars are developing new orientations } \\
\text { for the study of Colombian agrarian themes. The empirical work, however, remains } \\
\text { to be done". (p.29) }\end{array}$ \\
\hline $\begin{array}{c}\text { Observaciones } \\
\text { sobre la fuente }\end{array}$ & $\begin{array}{l}\text { El presente se configura como un estado del arte sobre historia rural y política } \\
\text { en Colombia. Su objetivo general es determinar una ruta de investigación para } \\
\text { la comprensión de los desarrollos de la política en el país. La autora relaciona } 4 \\
\text { perspectivas con el problema de la política rural, que son a saber: campesinos y } \\
\text { rebelión; la interacción de la política } \\
\text { nacional y local; las relaciones patrón-cliente; y el regionalismo. }\end{array}$ \\
\hline
\end{tabular}

\begin{tabular}{r|l}
\hline Cita & Miranda Ontaneda, Néstor. Clientelismo y dominio de clase. Bogotá: Cinep, 1977. \\
\hline Año & 1977 \\
\hline $\begin{array}{r}\text { Enfoque } \\
\text { teórico }\end{array}$ & Marxista \\
enunciadas & Enfoque marxista; distribución de bienes; poder real o fingido de los intermediarios. \\
\hline Hipótesis & $\begin{array}{l}\text { "Nuestra hipótesis es que en Colombia, al igual que en muchos otros países, se hace } \\
\text { política en la medida en que la distribución de estos bienes es mediatizada por los } \\
\text { partidos actuando a manera de demiurgos los intermediarios (gamonales, caciques, } \\
\text { etc.), quienes cimentan su poder por el manejo real o fingido de los mismos". (p. 34) }\end{array}$ \\
\hline $\begin{array}{l}\text { Observaciones } \\
\text { sobre la fuente }\end{array}$ & $\begin{array}{l}\text { Miranda Ontaneda es uno de los primeros académicos que incursiona en el tema del } \\
\text { clientelismo político en Colombia. Las investigaciones a su cargo, que se realizaron } \\
\text { en el Cinep desde 1975 a 1978, tenían como objetivo romper con el enfoque a } \\
\text { histórico y funcionalista típico de la época. Por el contrario, este grupo de autores } \\
\text { enmarcaron la discusión dentro del enfoque marxista, en el cual el clientelismo } \\
\text { es asumido como un mecanismo de instrumentalización del ser humano para } \\
\text { la conservación del poder de las élites políticas. Dicho en términos de Miranda } \\
\text { Ontaneda, el clientelismo es asumido como una herramienta de dominación } \\
\text { de clase. Los estudios dirigidos por Miranda Ontaneda son importantes en la } \\
\text { medida en que traen a Colombia un tema de análisis que está en el ojo del mundo } \\
\text { por esa época. El clientelismo es puesto sobre la mesa de una manera teórica y } \\
\text { rigurosa y deja un precedente en la forma de abordar el fenómeno con miras a } \\
\text { producir estudios de caso que expliquen la realidad colombiana de diferentes } \\
\text { regiones. Para Miranda, la política colombiana está dada a partir de mecanismos } \\
\text { de intermediación administrados por una clase política que sustentan la base de su } \\
\text { poder en manejo real o fingido de bienes que en teoría deberían ser repartidos a la } \\
\text { ciudadanía. }\end{array}$ \\
\hline
\end{tabular}




\begin{tabular}{r|l}
\hline Cita & $\begin{array}{l}\text { Reyes, Alejandro. Latifundio y poder político: la hacienda ganadera en Sucre. Bogotá: } \\
\text { Cinep, 1978. }\end{array}$ \\
\hline Año & 1978 \\
\hline $\begin{array}{r}\text { Enfoque } \\
\text { teórico }\end{array}$ & Marxista \\
\hline $\begin{array}{r}\text { Categorías } \\
\text { enunciadas }\end{array}$ & Instituciones coloniales; la hacienda. \\
\hline Hipótesis & $\begin{aligned} \text { "La estructura regional que nos hemos propuesto estudiar, así sea de manera } \\
\text { preliminar y descriptiva, se circunscribe al actual departamento de Sucre. Aunque } \\
\text { Sucre comprende varias regiones geográficas (costa o golfo de Morrosquillo, } \\
\text { Montes de María, Sabanas de Sucre y Ciénagas del Bajo Cauca y Bajo San Jorge), } \\
\text { la estructura regional más importante corresponde a las Sabanas. Estas, a su vez, } \\
\text { constituyen buena parte de las tradicionalmente conocidas 'Sabanas de Bolívar', } \\
\text { Departamento del cual formaba parte Sucre hasta 1968. Las 'Sabanas de Bolívar' } \\
\text { constituyen el asiento principal, desde la Colonia hasta hoy, de la típica hacienda } \\
\text { latifundista ganadera de la Costa Nor-Occidental de Colombia. Las relaciones de } \\
\text { producción propias de la hacienda han sido aquíl las determinantes de la producción, } \\
\text { las clases y los conflictos sociales. Podría postularse incluso la existencia de un } \\
\text { modelo de obrar político y una ideología justificadora asociados a las relaciones de } \\
\text { producción características de la hacienda ganadera”. }\end{aligned}$ \\
\hline $\begin{array}{l}\text { Observaciones } \\
\text { sobre la fuente }\end{array}$ & $\begin{array}{l}\text { Esta investigación pertenece al conjunto de investigaciones publicadas por el Cinep } \\
\text { enmarcadas dentro del enfoque marxista. La investigación hace una aproximación } \\
\text { regional del clientelismo buscando encontrar vínculos con el modelo de producción } \\
\text { basado en la hacienda ganadeara, esquema típico del departamento de Sucre. }\end{array}$ \\
\hline
\end{tabular}

\begin{tabular}{r|l}
\hline Cita & Valenzuela Ramírez, Jorge. Producción arrocera y clientelismo. Bogotá: Cinep, 1978. \\
\hline Año & 1978 \\
\hline $\begin{array}{r}\text { Enfoque } \\
\text { teórico }\end{array}$ & Marxista \\
enunciadas & Capitalismo; desarrollo económico; sindicalismo. \\
\hline Hipótesis & $\begin{array}{l}\text { "Lo anterior permite precisar un poco más el objeto de este estudio. Se trata de } \\
\text { relacionar los rasgos fundamentales de la estructura económica regional de Sucre } \\
\text { con el modo como están organizadas las instituciones políticas y como operan } \\
\text { concretamente los mecanismos de poder que garantizan la conservación de las } \\
\text { relaciones de producción". (p. 2-3) }\end{array}$ \\
\hline Observaciones \\
sobre la fuente
\end{tabular} \begin{tabular}{l} 
Esta investigación hace parte del conjunto de estudios de caso que desarrolló el \\
$\begin{array}{l}\text { Cinep a propósito de los estudios sobre clientelismo que venían desarrollándose } \\
\text { a lo largo de la década de los setenta. Este estudio se centra en la producción } \\
\text { arrocera del Huila, considerando que dicho sector representa el mayor eje de } \\
\text { desarrollo capitalista en el momento. La investigación parte del presupuesto de } \\
\text { que es necesario estudiar la estructura social para poder entender cómo es que esa } \\
\text { estructura social, a partir de unas relaciones de producción, da noción de las clases } \\
\text { y de los intereses de las mismas. Para el autor, hay una relación estrecha entre lo } \\
\text { económico y lo político: de esta manera, la economía capitalista, cuando empieza a } \\
\text { aplicarse aceleradamente en un territorio determinado, es absorbida por las formas } \\
\text { tradicionales de hacer política, determinando asílas nuevas relaciones de producción. } \\
\text { El clientelismo es visto como una herramienta de dominación. }\end{array}$ \\
\hline
\end{tabular}




\begin{tabular}{r|l}
\hline Cita & $\begin{array}{l}\text { Vasco, Eló́sa. Clientelismo y minifundio: bases socio-económicas del poder político en un } \\
\text { municipio minifundista. Bogotá: Cinep, 1978. }\end{array}$ \\
\hline Año & 1978 \\
\hline $\begin{array}{r}\text { Enfoque } \\
\text { teórico }\end{array}$ & Marxista \\
enunciadas & Poder local; poder nacional; burocracia estructurada sobre el poder burocrático. \\
\hline Hipótesis & $\begin{array}{l}\text { "El examen de la estructura de poder local y de su ejercicio y vinculación con } \\
\text { instancias superiores de poder revela, sin embargo, una estrecha relación entre lo } \\
\text { económico y el modo de obrar político, en el sentido de que la actividad política } \\
\text { tiene, en alto grado, un contenido económico. Este nexo esta mediado por } \\
\text { mecanismos que aquí se denominan 'clientelistas', y que tradicionalmente se han } \\
\text { designado por los nombretes de 'caciquismo'y 'gamonalismo'. Los bajos niveles } \\
\text { de ingreso y la pobreza de la población hacen que la obtención de ciertos bienes } \\
\text { y servicios tales como la educación y empleo esté estrechamente relacionada con } \\
\text { estos mecanismos, apuntando así una relación entre lo económico y lo político, no } \\
\text { a través del control de los medios de producción, sino estructurada sobre el poder } \\
\text { burocrático". (p. 63) }\end{array}$ \\
\hline $\begin{array}{r}\text { Observaciones } \\
\text { sobre la fuente }\end{array}$ & $\begin{array}{l}\text { La obra estudia el sistema de producción minifundista. Este es visto como una } \\
\text { forma de producción precapitalista que se articula de tal forma que permea todas las } \\
\text { estructuras burocráticas del poder público. La sobreposición de lo económico sobre } \\
\text { lo político se da por hecha, no por la posesión de los medios de producción, como } \\
\text { lo afirmarían posturas marxistas, sino por la posibilidad de intermediación de unos } \\
\text { grupos reducidos para la obtención de servicios básicos como lo son la educación, el } \\
\text { acceso al agua y el empleo. Se concluye que las formas de producción son típicas de } \\
\text { un estado precapitalista, estas prácticas, junto con la estructura política tradicional, } \\
\text { oprimen al campesinado, imposibilitando nuevas formas de asociación que den } \\
\text { fuerza económica y política que permitan hacer frente a los sectores opresores. }\end{array}$ \\
\hline
\end{tabular}

\begin{tabular}{|c|c|}
\hline Cita & $\begin{array}{l}\text { Alviar Nieto, Mario. "Clientelismo y participación política: el caso de la juventud } \\
\text { liberal". Enfoques colombianos (1980): 107-127. }\end{array}$ \\
\hline Año & 1980 \\
\hline $\begin{array}{r}\text { Enfoque } \\
\text { teórico }\end{array}$ & Marxista \\
\hline $\begin{array}{r}\text { Categorías } \\
\text { enunciadas }\end{array}$ & Participación política \\
\hline Hipótesis & $\begin{array}{l}\text { El autor no tiene una hipótesis que parte del siguiente presupuesto: "Los vicios, } \\
\text { errores y confusiones que han acompañado al desarrollo de la acción política } \\
\text { liberal de los últimos años particularmente a partir del frente nacional y el llamado } \\
\text { 'gobierno puente'-no solo han- producido apatía y la incredulidad, sino que } \\
\text { también se han trasladado con su carga negativa a los sectores de la juventud que } \\
\text { todavía participa en la actividad política. Teniendo como resultado, el que esa } \\
\text { juventud reproduce nuevamente en su trabajo político toda la deformada acción de } \\
\text { la vieja y anquilosada 'clase política' colombiana". (p. 108) }\end{array}$ \\
\hline $\begin{array}{l}\text { Observaciones } \\
\text { sobre la fuente }\end{array}$ & $\begin{array}{l}\text { El presente es un ensayo sobre la participación política de las juventudes liberales } \\
\text { en política. No maneja una hipótesis pero maneja la siguiente idea: en el contexto } \\
\text { de la crisis de legitimidad que vivió el sistema político en la década de los setenta, se } \\
\text { plantea la necesidad de incluir a los jóvenes en la participación política. }\end{array}$ \\
\hline
\end{tabular}




\begin{tabular}{r|l}
\hline Cita & $\begin{array}{l}\text { Arocha Rodríguez, Jaime. “Clientelismo, gasto y violencia”. Enfoques colombianos } \\
(1980) .\end{array}$ \\
\hline Año & 1980 \\
\hline $\begin{array}{r}\text { Enfoque } \\
\text { teórico }\end{array}$ & Marxista \\
\hline $\begin{array}{r}\text { Categorías } \\
\text { enunciadas }\end{array}$ & $\begin{array}{l}\text { Funcionalismo; Marxismo; paternalismo; distribución; reciprocidad; clases; } \\
\text { explotación; violencia; subculturas; estabilidad del sistema. }\end{array}$ \\
\hline Hipótesis & $\begin{aligned} \text { "Visualizo el clientelismo en términos de unas relaciones caracterizadas por la } \\
\text { confluencia del paternalismo, la reciprocidad, la mediación entre dos grupos } \\
\text { sociales y la explotación, y activadas por la inseguridad social generada por la } \\
\text { escasez de algún factor de producción. La simultaneidad de estas cualidades en el } \\
\text { vínculo entre dos personas define la especificidad del clientelismo, sin reducirlo } \\
\text { al comportamiento electoral, y a la vez impidiendo su asimilación al concepto de } \\
\text { subcultura. Esta visión me fue sugerida por la forma como los quindianos han } \\
\text { solucionado situaciones que pueden llamarse de 'emergencia'. Me referiré a dos } \\
\text { de ellas en este escrito. La primera se inició por la escasez del capital de trabajo; la } \\
\text { segunda, por la falta de tierra y trabajo durante la violencia”. (p. 50) }\end{aligned}$ \\
\hline $\begin{array}{l}\text { Observaciones } \\
\text { sobre la fuente }\end{array}$ & $\begin{array}{l}\text { Este artículo es importante para nuestro estudio en la medida en que aclara } \\
\text { concretamente cuáles fueron los primeros puntos de debate dentro del estudio del } \\
\text { clientelismo político en Colombia. Plantea, de forma clara y con una visión amplia } \\
\text { del problema, críticas a las reformas constitucionales que desde los años setenta } \\
\text { querían dar muerte al clientelismo. }\end{array}$ \\
\hline
\end{tabular}

\begin{tabular}{r|l}
\hline Cita & $\begin{array}{l}\text { Dávila Ladrón de Guevara, Andrés. “Clientelismo, intermediación y representación } \\
\text { política en Colombia: ¿Qué ha pasado en los noventa?". Estudios Políticos (1999): 62-78. }\end{array}$ \\
\hline $\begin{array}{r}\text { Eño } \\
\text { teórico }\end{array}$ & 1999 \\
\hline $\begin{array}{r}\text { Categorías } \\
\text { enunciadas }\end{array}$ & Institucionalista \\
\hline Hipótesis & $\begin{array}{l}\text { "Como hipótesis planteo que, en el caso colombiano, se ha pasado del clientelismo } \\
\text { moderno -caracterizado como sistema político del clientelismo- a un clientelismo } \\
\text { de mercado, inicialmente caracterizado por Gutiérrez en el ya citado trabajo sobre } \\
\text { Bogotá. Este tránsito se ha propiciado por la puesta en marcha de la Constitución } \\
\text { de 1991 y permitirá entender cuál es la lógica que está predominando en el actual } \\
\text { sistema político, en la competencia por el poder político institucional bajo el } \\
\text { nuevo diseño institucional. Esto implica que la lógica del actual sistema político } \\
\text { se asienta en las características y componentes del clientelismo de mercado, el } \\
\text { cual se ha desarrollado bajo unas nuevas condiciones institucionales, conservando } \\
\text { plena vigencia pero, al mismo tiempo, sometiendo límites y problemas que ponen } \\
\text { en entredicho su hasta ahora inigualable capacidad para ofrecer estabilidad y } \\
\text { perdurabilidad al régimen político vigente". (p. 63) }\end{array}$ \\
\hline
\end{tabular}




\begin{tabular}{l|l}
\hline $\begin{array}{l}\text { Observaciones } \\
\text { sobre la fuente }\end{array}$ & $\begin{array}{l}\text { La hipótesis que plantea Andrés Dávila, en este texto particularmente, es que } \\
\text { el clientelismo, a diferencia de lo que algunos creen, no es un fenómeno que se } \\
\text { encuentre en crisis por las reformas que, con la constitución de 1991, pretendían } \\
\text { dar muerte al fenómeno. Arguye de forma contraria que la Constitución de 1991 } \\
\text { sí produjo cambios sustanciales en la forma de operación de los actores, por lo } \\
\text { que fue necesaria una reacomodación de las prácticas a las nuevas realidades } \\
\text { institucionales. Sin embargo, esto, antes que generar una crisis del clientelismo, ha } \\
\text { generado un fenómeno con características diferentes que muestra que el clientelismo } \\
\text { inversamente aparenta estar pasando por un buen momento. }\end{array}$ \\
\hline
\end{tabular}

\begin{tabular}{|c|c|}
\hline Cita & $\begin{array}{l}\text { Miranda Ontaneda, Néstor. "El poder político en Colombia”. Enfoques colombianos } \\
\text { (1980): 7-46. }\end{array}$ \\
\hline Año & 1980 \\
\hline $\begin{array}{r}\text { Enfoque } \\
\text { teórico }\end{array}$ & Marxista \\
\hline $\begin{array}{r}\text { Categorías } \\
\text { enunciadas }\end{array}$ & $\begin{array}{l}\text { Capitalismo, desarrollo y democracia; instituciones coloniales; teoría dialéctica del } \\
\text { clientelismo; partidos. }\end{array}$ \\
\hline Hipótesis & $\begin{array}{l}\text { Es difícil identificar una hipótesis, sin embargo hay varias preguntas, entre ellas } \\
\text { la siguiente: "El desarrollo del capitalismo en Colombia se cumple por un camino } \\
\text { diferente al seguido por los países europeos; de esta manera, en términos de política } \\
\text { y concretamente en el contexto de lo que hemos denominado clientelismo, cabe } \\
\text { hacerse la siguiente pregunta: ¿Por qué unos países paralelamente con el tránsito } \\
\text { al modo de producción capitalista adoptan el modelo de organización política } \\
\text { más diferenciado que se ha dado en llamar democracia, al paso que otros siguen } \\
\text { practicando el modelo elemental que hemos denominado clientelismo?" (p. 44) }\end{array}$ \\
\hline $\begin{array}{c}\text { Observaciones } \\
\text { sobre la fuente }\end{array}$ & $\begin{array}{l}\text { Miranda Ontaneda es un autor obligado para todos aquellos que se interesen } \\
\text { por estudiar el tema del clientelismo. Conservo la hipótesis de que este autor } \\
\text { desde Europa - lugar en el cual el clientelismo político presentaba un boom- es } \\
\text { quien introduce el debate académico en Colombia a partir de la exposición de los } \\
\text { dos grandes paradigmas que rodeaban el problema, a saber, el funcionalismo y el } \\
\text { marxismo. Como pocos, este autor se interesa por exponer las diferencias entre } \\
\text { los enfoques y marcar abiertamente una posición entre ellos. De entrada, el autor } \\
\text { identifica el fenómeno del clientelismo como una herramienta de dominación de } \\
\text { clase, postulado típico del enfoque marxista. Desde allí, el autor se dirige a la obra } \\
\text { de Guillén Martínez, reconociendo que este trabaja con categorías weberianas; } \\
\text { hace una análisis crítico del trasfondo teórico de la obra histórica de Guillén } \\
\text { Martínez; mas sin embargo, reconoce la importancia de esta obra, posicionándola } \\
\text { como una forma de génesis del poder político en Colombia, en la cual las formas de } \\
\text { agrupación, tales como la encomienda, la hacienda y posteriormente el sindicalismo } \\
\text { se articulan como mecanismos sutiles pero efectivos de dominación de las élites. } \\
\text { Los posteriores desenlaces en los estudios del clientelismo político en Colombia } \\
\text { no habrían sido los mismos sin las bases de la obra de Guillén, donde el papel } \\
\text { articulador de los gamonales luego en la clase política daría absoluto sentido a las } \\
\text { relaciones establecidas entre partidos a nivel burocrático. }\end{array}$ \\
\hline
\end{tabular}

\begin{tabular}{r|l}
\hline Cita & $\begin{array}{l}\text { Díaz Uribe, Eduardo. El clientelismo en Colombia: Un estudio exploratorio. Bogotá: } \\
\text { Âncora Editores, 1986. }\end{array}$ \\
\hline Año & 1986 \\
\hline
\end{tabular}




\begin{tabular}{r|l}
\hline $\begin{array}{r}\text { Enfoque } \\
\text { teórico }\end{array}$ & Marxista \\
\hline $\begin{array}{r}\text { Categorías } \\
\text { enunciadas }\end{array}$ & Administración pública; desarrollo económico; Costa Atlántica. \\
\hline Hipótesis & $\begin{array}{l}\text { "Bajo las consideraciones de que, si bien el clientelismo es un fenómeno } \\
\text { generalizado, se ha hecho más notorio en la costa Caribe, por razones que es } \\
\text { necesario estudiar, y de que existe una estrecha relación entre el clientelismo y } \\
\text { el mayor o menor grado de atraso económico relativo, se decidió adelantar la } \\
\text { investigación en esta zona del país. No obstante, fue necesario delimitar aun más } \\
\text { el marco espacial del ejercicio en su primera etapa, toda vez que la Costa Atlántica } \\
\text { comprende un vasto territorio". (p. 14) }\end{array}$ \\
\hline $\begin{array}{r}\text { Observaciones } \\
\text { sobre la fuente }\end{array}$ & $\begin{array}{l}\text { Eduardo Díaz hace una investigación que parte de las investigaciones realizadas } \\
\text { en el Cinep. El objetivo de la investigación es identificar la racionalidad operante } \\
\text { en cuanto a los procesos políticos y de gestión pública en el nivel regional, } \\
\text { partiendo del examen de los fenómenos presentes en las esferas de lo político y lo } \\
\text { administrativo. }\end{array}$ \\
\hline
\end{tabular}

\begin{tabular}{r|l}
\hline Cita & $\begin{array}{l}\text { Miranda Talero, Alfonso. "Del manzanillismo al clientelismo presupuestal". } \\
\text { Areopago (1987): 24-25. }\end{array}$ \\
\hline Año & 1987 \\
\hline $\begin{array}{r}\text { Enfoque } \\
\text { teórico }\end{array}$ & Institucionalista \\
\hline $\begin{array}{r}\text { Categorías } \\
\text { enunciadas }\end{array}$ & Reforma presupuestal; reforma de 1968 \\
\hline Hipótesis & $\begin{array}{l}\text { Las reformas en materia presupuestal hechas en } 1968 \text { contribuyen al clientelismo } \\
\text { presupuestal. }\end{array}$ \\
\hline $\begin{array}{l}\text { Observaciones } \\
\text { sobre la fuente }\end{array}$ & $\begin{array}{l}\text { Este artículo muestra algunas de las pugnas que se producen entre el legislativo y el } \\
\text { ejecutivo a propósito de las reformas presupuestales. El artículo formula un conjunto } \\
\text { de críticas a la reforma de 1968. }\end{array}$ \\
\hline
\end{tabular}

\begin{tabular}{r|l}
\hline Cita & $\begin{array}{l}\text { Echavarría Córdoba, Jaime y Julio C. Hálaby Córdoba. Sociología política de comicios y } \\
\text { clientelismo. Chocó: Universidad Tecnológica del Chocó, 1988. }\end{array}$ \\
\hline Año & 1988 \\
\hline $\begin{array}{r}\text { Enfoque } \\
\text { teórico }\end{array}$ & Marxista \\
\hline $\begin{array}{r}\text { Categorías } \\
\text { enunciadas }\end{array}$ & $\begin{array}{l}\text { Participación política; dominio de clase; grupo con poder; grupo excluido y } \\
\text { dominado. }\end{array}$ \\
\hline Hipótesis & "El presente estudio pretende caracterizar el comportamiento electoral y las \\
& $\begin{array}{l}\text { actitudes de la población del Departamento del Chocó en la política, teniendo } \\
\text { en cuenta variables económico-demográficas (educación, ocupación),y algunas } \\
\text { actividades específicas (afiliación partidista, racionalidad, tradición) que permitan } \\
\text { sacar algunas conclusiones del denominado efecto clientelista. Para el trabajo de } \\
\text { campo se usó el modelo instrumental propuesto por la Facultad de Altos Estudios } \\
\text { Interdisciplinarios de la Universidad Javeriana, el cual se aplicó en tres municipios } \\
\text { del Chocó: Quibdó (capital departamental), Tadó e Istmina". (p. 9) }\end{array}$ \\
\hline
\end{tabular}




\begin{tabular}{l|l}
\hline $\begin{array}{l}\text { Observaciones } \\
\text { sobre la fuente }\end{array}$ & $\begin{array}{l}\text { La identificación del enfoque del presente texto presentó dificultades debido a la } \\
\text { cantidad de autores, de todas las tendencias, a los que se hace referencia, entre ellos } \\
\text { los siguientes: Vasco, Miranda, Losada, Fals Borda, Francisco Posada, Gilberto } \\
\text { Tobón, Liévalo, Colmenares, Tirado, Mejía y Gerardo Molina. Sin embargo, la } \\
\text { importancia dada al concepto de clase marca una línea clara aún cuando se hace un } \\
\text { llamado al enfoque racional y psicosocial para el análisis electoral de los votantes } \\
\text { en el departamento del Chocó. El estudio relaciona algunos factores que influyen } \\
\text { en el comportamiento electoral, tales como: la tradición; la cultura; lo emocional } \\
\text { sobre lo racional; la imagen sobre el discurso; y la geografía de los partidos en el } \\
\text { departamento de Chocó. }\end{array}$ \\
\hline
\end{tabular}

\begin{tabular}{|c|c|}
\hline Cita & $\begin{array}{l}\text { Dávila Ladrón de Guevara, Andrés y Delgado Valera, Natalia. "La metamorfosis } \\
\text { del sistema político colombiano: ¿Clientelismo de mercado o nueva forma de } \\
\text { intermediación?" En Degradación o cambio: evolución del sistema politico colombiano, } \\
\text { compilado por Francisco Gutiérrez Sanín, 319-356. Bogotá: Editorial Norma, } \\
2002 \text {. }\end{array}$ \\
\hline Año & 2002 \\
\hline $\begin{array}{r}\text { Enfoque } \\
\text { teórico }\end{array}$ & Institucionalista \\
\hline $\begin{array}{r}\text { Categorías } \\
\text { enunciadas }\end{array}$ & Clientelismo de mercado; intermediación política; Constitución política de 1991. \\
\hline Hipótesis & $\begin{array}{l}\text { "Este artículo sugiere entender al clientelismo dentro del contexto específico de } \\
\text { cada sociedad. Es por ello que, dados los cambios que ha sufrido Colombia desde la } \\
\text { Constitución de } 1991 \text { y a pesar de que esta reforma pretendía ser un pacto refundacional } \\
\text { para superar la vieja política, el clientelismo se adecuó a este nuevo escenario y acabó por } \\
\text { adaptarlo a sus requerimientos para continuar siendo parte fundamental de la manera de } \\
\text { hacer política en Colombia. Esta ininterrumpida presencia del clientelismo obliga a ver este } \\
\text { fenómeno, no como una enfermedad del sistema político, sino como una relación que por } \\
\text { mucho tiempo ha generado un mecanismo de interacción o de intercambio entre diferentes } \\
\text { sectores sociales. En los últimos tres años, el resurgimiento de una nueva preocupación por } \\
\text { el clientelismo ha llevado a sugerir nuevas hipótesis o a renovar antiguas tesis sobre este } \\
\text { fenómeno. Algunas de estas tesis sugieren que se ha generado una nueva organización de } \\
\text { las relaciones clientelistas que apuntan hacia un nuevo tipo de clientelismo, denominado } \\
\text { 'clientelismo de mercado'. } \\
\text { A pesar de que el modelo de clientelismo de mercado tiene todavía un carácter } \\
\text { eminentemente hipotético, este trabajo está enfocado a responder la siguiente pregunta } \\
\text { que, de entrada, va un paso más allá: dlas relaciones clientelistas que se han desarrollado } \\
\text { en los últimos diez años corresponden a una nueva caracterización del tradicional tipo de } \\
\text { relaciones de intermediación, organizando bajo la forma de un modelo de mercado distinto } \\
\text { al previamente vigente? ¿O corresponde a un nuevo tipo de relaciones de intermediación } \\
\text { que coincide con un nuevo diseño institucional y un contexto social cambiante, pero } \\
\text { cuyos resultados siguen siendo desfavorables para la sociedad colombiana, en términos } \\
\text { del funcionamiento y calidad de la democracia? Pese a la aparente complejidad de la } \\
\text { pregunta, lo que inquieta es saber si el sistema político colombiano experimenta una fase } \\
\text { relativamente nueva de una tradicional forma de intercambio político, o si ha transitado } \\
\text { hacia una redefinición de los mecanismos de intermediación que, sin embargo, se } \\
\text { construyen dentro de esquemas y prácticas que no parecen mejorar el funcionamiento y } \\
\text { calidad del sistema político". (p. 326-327) }\end{array}$ \\
\hline
\end{tabular}




\begin{tabular}{l|l}
\hline $\begin{array}{l}\text { Observaciones } \\
\text { sobre la fuente }\end{array}$ & $\begin{array}{l}\text { Los autores sugieren que en la medida en que hay una transformación del } \\
\text { sistema político, del marco institucional y del desarrollo económico se generan } \\
\text { transformaciones en las formas de intermediación política, dando paso a nuevas } \\
\text { formas de intermediación clientelista. El artículo hace una revisión de categorías } \\
\text { ad hoc que ya han sido trabajadas por otros autores, como las de clientelismo } \\
\text { tradicional, moderno y de mercado. Lo anterior con el fin contribuir a la ratificación } \\
\text { de la hipótesis ya formulada en otros trabajos por Gutiérrez y Dávila, en la cual se } \\
\text { habla de una nueva tipología de clientelismo, el de mercado, el cual, por el tipo de } \\
\text { marco institucional en el que se desenvuelve, exhibe unas características no ajenas a } \\
\text { la formación de mecanismos de representación y participación. }\end{array}$ \\
\hline
\end{tabular}

\begin{tabular}{r|l}
\hline Cita & $\begin{array}{l}\text { Sudarsky, John. Clientelismo y Desarrollo Social. Bogotá: Tercer Mundo Editores, } \\
1988 .\end{array}$ \\
\hline Año & 1988 \\
\hline $\begin{array}{r}\text { Enfoque } \\
\text { teórico }\end{array}$ & Institucionalista \\
enunciadas & Desarrollo; equidad; modernidad; Estado neo patrimonial; cooperativas. \\
\hline Hipótesis & $\begin{array}{l}\text { "Las cooperativas secundarias o federaciones de cooperativas, al unir un conjunto } \\
\text { de asociaciones primarias, están en capacidad de proveer ciertos conocimientos } \\
\text { especializados y servicios que una unidad simple no podría costearse: mercadeo } \\
\text { y procesamiento de productos en términos regionales, crédito y educación. En } \\
\text { el sentido político, la importancia de estas federaciones radica en la posibilidad } \\
\text { de crecer y fortalecerse lo suficiente como para movilizar apoyo, y con este lograr } \\
\text { acceso autónomo a los diferentes centros de decisión, lo cual, como se ha expuesto, } \\
\text { permitiría modificar relativamente la situación de sus miembros dentro de la } \\
\text { sociedad. Aún más: si los miembros de las cooperativas mantienen una participación } \\
\text { activa y hacen oír su voz en las cooperativas secundarias, sostienen comunicación } \\
\text { de dos vías y exigen públicamente que las actuaciones de las directivas de las } \\
\text { cooperativas se ajusten a las obligaciones que les han encomendado los asociados, el } \\
\text { proceso que allíse dé será un modelo significativo para la actuación de los miembros } \\
\text { en la sociedad nacional: las cooperativas serán una verdadera escuela de democracia". } \\
\text { (p.19-20) }\end{array}$ \\
\hline $\begin{array}{l}\text { Observaciones } \\
\text { sobre la fuente }\end{array}$ & $\begin{array}{l}\text { El autor da respuesta al problema del desarrollo con equidad. Las cooperativas } \\
\text { son tomadas como una herramienta de acción comunitaria que tienen como fin } \\
\text { organizar a sectores con bajos recursos y así brindarles soporte financiero. Sudarsky } \\
\text { hace una descripción de la sociedad en la que intenta aplicar el modelo de la } \\
\text { cooperativa, tomando a Colombia como una sociedad caracterizada por ser neo- } \\
\text { patrimonial, dentro de esta definición bien cabe acomodar el modelo clientelista y } \\
\text { otras características como el choque entre modernidad y tradición. }\end{array}$ \\
\hline
\end{tabular}

\begin{tabular}{r|l}
\hline Cita & $\begin{array}{l}\text { Dávila Ladrón de Guevara, Andrés y García, Sánchez Miguel. “Control político y } \\
\text { control ciudadano en Bogotá”. En Servicio Civil y mecanismos de control, 2000. }\end{array}$ \\
\hline Año & 2000 \\
\hline $\begin{array}{r}\text { Enfoque } \\
\text { teórico }\end{array}$ & Institucionalista \\
\hline
\end{tabular}




\begin{tabular}{|c|c|}
\hline $\begin{array}{r}\text { Categorías } \\
\text { enunciadas }\end{array}$ & $\begin{array}{l}\text { Control político; diseños institucionales; ciudadanía; relaciones adminsitración- } \\
\text { Concejo; intermediación clientelista; Bogotá. }\end{array}$ \\
\hline Hipótesis & $\begin{array}{l}\text { "Las preguntas a las que se intenta dar respuesta parten de cuestionamientos } \\
\text { esenciales sobre el funcionamiento de la política en Bogotá y acerca de las relaciones } \\
\text { entre Alcaldía y Consejo, autoridades, representantes y ciudadanía, con el fin de } \\
\text { examinar el desenvolvimiento de las relaciones políticas en la ciudad, especialmente } \\
\text { en lo atinente a las modalidades de control vertical y horizontal existentes. No } \\
\text { obstante, resulta fundamental añadir algunas cuestiones adicionales para precisar } \\
\text { el sentido del ejercicio adelantado, especialmente en relación con los diseños } \\
\text { institucionales y las reglas del juego vigentes, así como con las posibles y deseables } \\
\text { para el caso en cuestión".(p. 1) }\end{array}$ \\
\hline $\begin{array}{r}\text { Observaciones } \\
\text { sobre la fuente }\end{array}$ & $\begin{array}{l}\text { Miguel García y Andrés Dávila parten del presupuesto de que en Bogotá ha } \\
\text { convivido un diseño institucional híbrido en el cual coexisten características del } \\
\text { modelo republicano, con su división de poderes, y componentes de la democracia } \\
\text { participativa. Este modelo, junto con la aplicación incompleta de fórmulas } \\
\text { descentralizadoras, atomizadoras y desconcentradoras han terminado por producir } \\
\text { un modelo de intermediación clientelista crecientemente personalizada, que se } \\
\text { materializa entre las negociaciones entre la administración central y el consejo. Ante } \\
\text { este panorama, la investigación plantea un diagnóstico sobre el control ejercido } \\
\text { desde la esfera política y el ámbito de la ciudadanía, para así, en una segunda parte, } \\
\text { proponer algunos cambios en el diseño institucional de la ciudad. }\end{array}$ \\
\hline
\end{tabular}

\begin{tabular}{r|l}
\hline Cita & $\begin{array}{l}\text { Uprimny, Rodrigo. "Legitimidad, clientelismo y política en Colombia: Un ensayo de } \\
\text { interpretación". Cuadernos de Economía x (1989): 113-164. }\end{array}$ \\
\hline Año & 1989 \\
\hline $\begin{array}{r}\text { Enfoque } \\
\text { teórico }\end{array}$ & Marxista \\
enunciadas & Élites políticas y económicas; régimen neopatrimonial. \\
\hline Hipótesis & $\begin{array}{l}\text { "En síntesis, la hipótesis que proponemos es la de que debido al carácter } \\
\text { neopatrimonial del Estado colombiano las unciones de legitimación y acumulación } \\
\text { propias de la intervención estatal se disocian: las organizaciones partidistas } \\
\text { encuadran la población y legitiman la dominación política mientras que la defensa } \\
\text { de los intereses socioeconómicos toma vías pretendidamente apolíticas y privadas. } \\
\text { Esta disociación de las élites políticas y económicas también parece darse a nivel } \\
\text { regional aún cuando es mucho más evidente en el plano nacional. En Efecto, el } \\
\text { intento de distanciarse de las definiciones políticas partidistas parece haber sido una } \\
\text { constante de la actividad gremial, sobre todo en épocas de crisis y de agudización } \\
\text { del enfrentamiento partidista, como si los representantes de las fracciones } \\
\text { hegemónicas hubiesen entendido mucho antes que los investigadores en ciencias } \\
\text { sociales que dentro del contexto colombiano, el capital no tiene color político. Eso } \\
\text { es particularmente claro, por ejemplo, en la época de la 'violencia', periodo durante el } \\
\text { cual la agudización del conflicto bipartidista y la creciente autonomía del escenario } \\
\text { político pusieron en peligro la dominación". (p. 144-145) }\end{array}$ \\
\hline
\end{tabular}




\begin{tabular}{l|l}
\hline $\begin{array}{l}\text { Observaciones } \\
\text { sobre la fuente }\end{array}$ & $\begin{array}{l}\text { Es un texto que toma elementos de diversos enfoques y tendencias, el mismo autor } \\
\text { reconoce la naturaleza ecléctica del mismo. Se reconocen elementos del enfoque } \\
\text { marxista, del cual toma elementos de la escuela de la derivación y postulados de la } \\
\text { teoría de la dependencia; por otro lado, adopta conceptos weberianos; y por último, } \\
\text { funcionalistas, desde donde el autor explica el clientelismo. El autor reconoce el } \\
\text { clientelismo como uno de los mecanismos de mantenimiento del poder de las élites } \\
\text { políticas y económicas, dentro de muchos otros. }\end{array}$ \\
\hline
\end{tabular}

\begin{tabular}{|c|c|}
\hline Cita & $\begin{array}{l}\text { Archer, Ronald P. The Transition from Traditional to Broker Clientelism in Colombia: } \\
\text { Political Stability and Social Unrest. Notre Dame, Indiana: Kellogg Institute for } \\
\text { International Studies, } 1990 .\end{array}$ \\
\hline Año & 1990 \\
\hline $\begin{array}{r}\text { Enfoque } \\
\text { teórico }\end{array}$ & Estructural-Funcionalista \\
\hline $\begin{array}{r}\text { Categorías } \\
\text { enunciadas }\end{array}$ & $\begin{array}{l}\text { Partidos tradicionales; estabilidad del régimen político; mecanismos de } \\
\text { intermediación clientelista; legitimidad socabada; intercambio de bienes por votos. }\end{array}$ \\
\hline Hipótesis & $\begin{array}{l}\text { "La capacidad de los partidos tradicionales de canalizar el apoyo a través de estructuras } \\
\text { clientelistas mientras que proporcionaban un impresionante grado de estabilidad } \\
\text { al régimen, socavó al mismo tiempo la legitimidad de la élite política y del Estado } \\
\text { y adicionalmente, hizo que la tarea de este último de proveer un desarrollo social, } \\
\text { político y económico fuera casi imposible en el largo plazo. El pueblo colombiano, } \\
\text { desarticulado por el mecanismo de intermediación clientelista no ha logrado crear } \\
\text { organizaciones funcionales que puedan representar sus intereses y necesidades ante el } \\
\text { Estado. Como resultado de ello, no sólo la legitimidad del Estado sufrió un detrimento, } \\
\text { sino que también lo hizo la capacidad estatal de proporcionar bienes y servicios } \\
\text { considerados más como derechos que como simples monedas de cambio por votos. } \\
\text { Como consecuencia de lo anterior, la autoridad del Estado, de los partidos tradicionales } \\
\text { y de la élite política se ha derrumbado mientras que los medios necesarios para } \\
\text { construir un capital social que permita restaurar la autoridad y la legitimidad siguen } \\
\text { estando lejos de mostrar una aparición. De esta forma, la escalada de los conflictos } \\
\text { sociales y el 'inmovilismó de un régimen político que una vez parecía monolítico, } \\
\text { muestra ser cada año más andrajoso y disparejo". (traducción del autor, p. 36) }\end{array}$ \\
\hline $\begin{array}{l}\text { Observaciones } \\
\text { sobre la fuente }\end{array}$ & $\begin{array}{l}\text { Se plantea como problema el hecho de que el término "clientelismo" sea } \\
\text { ampliamente usado para todo tipo de relaciones: se utiliza como algo oblicuo, } \\
\text { pero todavía hacen falta esfuerzos por comprender su forma de operación y de } \\
\text { reproducción del mismo, así como sus efectos. }\end{array}$ \\
\hline
\end{tabular}

\begin{tabular}{r|l}
\hline Cita & $\begin{array}{l}\text { Deas, Malcolm. "Algunas notas sobre el caciquismo en Colombia”. Revista de } \\
\text { Occidente tomo xuIII (1973). }\end{array}$ \\
\hline Año & 1973 \\
\hline $\begin{array}{r}\text { Enfoque } \\
\text { teórico }\end{array}$ & Institucionalista \\
\hline $\begin{array}{r}\text { Categorías } \\
\text { enunciadas }\end{array}$ & Caciquismo; Frente Nacional; reforma del ejecutivo, fenómeno atávico. \\
\hline
\end{tabular}




\begin{tabular}{r|l}
\hline Cita & $\begin{array}{l}\text { Echeverri Uruburu, Álvaro. Élites, clientelismo y burocracia estatal, 1960-1990. } \\
\text { Bogotá: Universidad Autónoma de Colombia, 1993. }\end{array}$ \\
\hline $\begin{array}{r}\text { Año } \\
\text { Enfoque } \\
\text { teórico }\end{array}$ & 1993 \\
\hline $\begin{array}{r}\text { Categorías } \\
\text { enunciadas }\end{array}$ & Élites políticas y económicas; modernización. \\
\hline Hipótesis & $\begin{array}{l}\text { El texto propone implícitamente la siguiente hipótesis: el poder del Estado ha } \\
\text { estado al servicio de las élites políticas y económicas del país, y los intereses de estas } \\
\text { han servido para el desarrollo económico y la modernización del mismo. }\end{array}$ \\
\hline $\begin{array}{r}\text { Observaciones } \\
\text { sobre la fuente }\end{array}$ & $\begin{array}{l}\text { Este autor se hace las siguientes preguntas: ¿Quiénes detentan efectivamente el } \\
\text { poder político en Colombia? ¿Cómo lo detentan, a través de cuales instancias } \\
\text { institucionales y en qué forma? A partir de estas preguntas el autor analiza la } \\
\text { procedencia de los principales cargos de los principales niveles institucionales del } \\
\text { aparato estatal donde se adoptan las decisiones fundamentales del país. Ante esto, se } \\
\text { concluye que dichos cargos han estado ocupados por élites económicas y políticas, } \\
\text { y que los intereses inmediatos de las élites económicas han conducido a Colombia } \\
\text { hacia procesos de modernización y desarrollo económico. }\end{array}$ \\
\hline
\end{tabular}

\begin{tabular}{r|l}
\hline Cita & $\begin{array}{l}\text { Medina, Medófilo. “Clientelismo: el sistema político y su expresión regional”. } \\
\text { Análisis Político (1991): 95-99. }\end{array}$ \\
\hline $\begin{array}{r}\text { Enfoque } \\
\text { teórico }\end{array}$ & 1993 \\
\hline $\begin{array}{r}\text { Categorías } \\
\text { enunciadas }\end{array}$ & Crisis política; sistema político colombiano. \\
\hline Hipótesis & $\begin{array}{l}\text { Es una reseña crítica. El concepto que emite el autor sobre el libro de Leal y Dávila } \\
\text { es el siguiente: "No obstante las observaciones críticas que se pueden formular, con } \\
\text { seguridad el lector encontrará que en el trabajo de Leal Buitrago y Dávila Ladrón } \\
\text { de Guevara, predominan con ventaja los momentos positivos tales como: el logro de } \\
\text { un modelo para la investigación del clientelismo a nivel regional, el esclarecimiento } \\
\text { de aspectos relevantes del funcionamiento del sistema político colombiano, la } \\
\text { sistematización de un conjunto de observaciones sobre la crisis política”. (p. 99) }\end{array}$ \\
\hline $\begin{array}{l}\text { Observaciones } \\
\text { sobre la fuente }\end{array}$ & $\begin{array}{l}\text { El presente es una reseña crítica sobre el libro de Leal y Dávila. Es importante en la } \\
\text { medida en que esboza los principales elementos del libro, así como resalta los puntos } \\
\text { débiles de la investigación. }\end{array}$ \\
\hline
\end{tabular}

\begin{tabular}{r|l}
\hline Cita & $\begin{array}{l}\text { Díaz, Fernando. "Dominación, clientelismo y desarrollo social en el Bajo Sinú". } \\
\text { Revista Universidad de Córdoba, (1994): 21-26. }\end{array}$ \\
\hline Año & 1994 \\
\hline $\begin{array}{r}\text { Enfoque } \\
\text { teórico }\end{array}$ & Marxista \\
\hline $\begin{array}{r}\text { Categorías } \\
\text { enunciadas }\end{array}$ & Comercio; propiedad de la tierra; poder político. \\
\hline
\end{tabular}




\begin{tabular}{c|l}
\hline Hipótesis & "Con el transcurso del tiempo y la evolución de la sociedad: ampliación de la base \\
demográfica, crecimiento del mercado y apertura comercial hacia otros puntos \\
de la Costa Caribe, el dominio del poder político y de la propiedad territorial \\
permitió a los antiguos 'magnates' obtener también el dominio del comercio, \\
unidos a empresarios de la Costa Caribe, en particular de Cartagena de Indias y de \\
Barranquilla. Tales conexiones los condujo a una vinculación a la política bolivarense \\
activa y al mismo tiempo convirtieron a Cartagena de Indias y a Barranquilla en \\
polos de desarrollo para el progresivo mejoramiento social y económico del Bajo \\
Sinú". (p. 25)
\end{tabular}

\begin{tabular}{r|l}
\hline Cita & $\begin{array}{l}\text { García Duarte, Ricardo. "El mercado político y la lógica de la clientela". Revista Foro } \\
(1994): 17-25 .\end{array}$ \\
\hline Año & 1994 \\
\hline $\begin{array}{r}\text { Enfoque } \\
\text { teórico }\end{array}$ & Institucionalista \\
\hline Categorías & $\begin{array}{l}\text { Elecciones; voto de opinión; empresas políticas; representación; minorías; voto } \\
\text { clientelista. }\end{array}$ \\
\hline Hipótesis & $\begin{aligned} \text { "Al mismo tiempo que se reduce el terreno para la reproducción de relaciones } \\
\text { típicamente clientelistas, se impone la lógica de construir pequeñas empresas } \\
\text { políticas de carácter personal, para concurrir en el mercado. La reproducción } \\
\text { ampliada del control clientelista encuentra limitaciones probablemente por efecto } \\
\text { de las reformas que se ha puesto en vigor después de 1991,y por la recrudecida } \\
\text { escasez de recursos institucionales o para institucionales, en manos de los } \\
\text { políticos profesionales. Por otra parte, la lógica de la concurrencia entre empresas } \\
\text { personalistas de carácter político se impone en razón del sistema proporcional } \\
\text { de escrutinio favorable en condiciones normales a las minorías, pero que en las } \\
\text { condiciones colombianas determina la transformación de las mayorías en una suma } \\
\text { infinita de minorías, mientras a estas las pone en peligro de desaparecer". (p. 19) }\end{aligned}$ \\
\hline $\begin{array}{l}\text { Observaciones } \\
\text { sobre la fuente }\end{array}$ & $\begin{array}{l}\text { La conclusión de este artículo es que la Constitución de 1991 introdujo reformas } \\
\text { electorales que tenían como propósito la modernización de la clase política. Sin } \\
\text { embargo, el abstencionismo de las elecciones de congresistas de 1994 puso en } \\
\text { evidencia el resultado de la implementación de dichas reformas en un contexto } \\
\text { como el colombiano. El autor señala que el resultado del fraccionamiento de los } \\
\text { dos grandes partidos tradicionales dejó una competencia entre clientelas de corte } \\
\text { personalista, lo que terminó por producir que las dos grandes mayorías se disolvieran } \\
\text { y se fragmentaran en una inmensa cantidad de minorías que terminaron quedando } \\
\text { fuera del juego político. El resultado es una convivencia entre el voto de opinión y el } \\
\text { voto clientelista, sin embargo, el voto de opinión sigue siendo débil en el país. }\end{array}$ \\
\hline
\end{tabular}

\begin{tabular}{r|l}
\hline Cita & $\begin{array}{l}\text { Alzate Cardona, Gilberto. Concentración de poder, violencia, clientelismo y democracia } \\
\text { participativa en Colombia. Bogotá: Pontificia Universidad Javeriana, 1995. }\end{array}$ \\
\hline Año & 1995 \\
\hline Enfoque & Marxista \\
teórico &
\end{tabular}




\begin{tabular}{r|l}
\hline $\begin{array}{r}\text { Categorías } \\
\text { enunciadas }\end{array}$ & $\begin{array}{l}\text { Concentración del poder, violencia y clientelismo; subdesarrollo; no progreso; } \\
\text { pobreza; la hacienda; bipartidismo. }\end{array}$ \\
\hline Hipótesis & $\begin{array}{l}\text { "Este tema del clientelismo, al lado de la violencia, obedece a que nosotros } \\
\text { consideramos, estas dos malignas enfermedades de nuestro cuerpo social, como } \\
\text { consecuencia directa y real de la excesiva concentración del poder en todas sus } \\
\text { manifestaciones de un lado, y por otra parte, de ese mayoritario sector de la sociedad } \\
\text { colombiana incapaz de satisfacer dignamente sus necesidades, generalmente por } \\
\text { falta de oportunidades y recursos, que las más de las veces estas oportunidades y } \\
\text { recursos, son acaparados, por el minoritario grupo detentador del poder". (p. 332) }\end{array}$ \\
\hline sobrervaciones la fuente & $\begin{array}{l}\text { El autor entiende el clientelismo como una relación social que está profundamente } \\
\text { relacionado con desenlaces históricos generados tanto por elementos del ambiente } \\
\text { como de la cultura. En dicho proceso, instituciones coloniales como la hacienda }\end{array}$ \\
& $\begin{array}{l}\text { y algunas características típicas del territorio nacional, tales como su diversidad } \\
\text { y fraccionamiento, dificultaron las dinámicas de mercados internos y con ello, } \\
\text { promovieron la concentración de poder de los hacendados. La aparición de partidos } \\
\text { y su configuración como subculturas promovieron la creación de cuerpos armados. } \\
\text { El bipartidismo transportaría relaciones semejantes a la administración pública, el } \\
\text { clientelismo se pone de manifiesto de diferentes maneras dependiendo del rol del sujeto } \\
\text { en medio de toda la estructura social, se manifiesta a partir del nombramiento arbitrario } \\
\text { de funcionarios públicos que no son sometidos a procedimientos meritocráticos; de la } \\
\text { compra de votos; del uso de fondos públicos para beneficios de particulares; del tráfico } \\
\text { de influencias, etc. El autor toma preceptos conceptuales tanto de Francisco Leal como } \\
\text { de Eduardo Díaz Uribe. Lo anterior se manifiesta al comprender el fenómeno como } \\
\text { constructor social, a la vez que lo denomina como una práctica que va en detrimento del } \\
\text { progreso económico y social, al asentarse sobre las bases del subdesarrollo. }\end{array}$ \\
\hline
\end{tabular}

\begin{tabular}{|c|c|}
\hline Cita & $\begin{array}{l}\text { Escalante, Fernando. "Clientelismo y ciudadanía en México: apuntes sobre la } \\
\text { conceptualización de las formas de acción política". Análisis Politico (1995): 31-41. }\end{array}$ \\
\hline Año & 1995 \\
\hline $\begin{array}{r}\text { Enfoque } \\
\text { teórico }\end{array}$ & Socio-antropológico \\
\hline $\begin{array}{l}\text { Categorías } \\
\text { enunciadas }\end{array}$ & Ciudadanía y democracia \\
\hline Hipótesis & $\begin{array}{l}\text { "La reducción de las formas de acción política a los términos genéricos de } \\
\text { 'clientelismo' 'ciudadanía' responde a la misma lógica, que casi obliga a suponerlos } \\
\text { encadenados en un orden de sucesión. La polaridad, de hecho, tiene sentido porque } \\
\text { sirve para estructurar un proceso histórico. No se trata, pues, de nada nuevo; } \\
\text { sin embargo, la hipótesis tiene un atractivo adicional, en los tiempos recientes, } \\
\text { porque se ajusta a las necesidades de la fórmula de moda acerca de la 'transición } \\
\text { a la democracia' [...] La hipótesis dice que la acción política evoluciona de las } \\
\text { formas 'clientelistas' a las formas 'ciudadanas', dice también que ese proceso es el } \\
\text { tránsito hacia la democracia [...] El error -porque creo que está equivocada- de } \\
\text { una interpretación semejante estriba en que necesita suponer demasiadas cosas. } \\
\text { Para empezar, necesita suponer que las dichas formas de acción política son } \\
\text { incompatibles; y es cosa que dista mucho de estar clara. La idea de que la condición } \\
\text { ciudadana de algún modo 'supera' a las otras formas de comportamiento político, en } \\
\text { efecto, es más bien resultado de un sesgo ideológico, de una interpretación moral } \\
\text { cuya justificación empírica es, por lo menos, problemática" (p. 32). }\end{array}$ \\
\hline
\end{tabular}




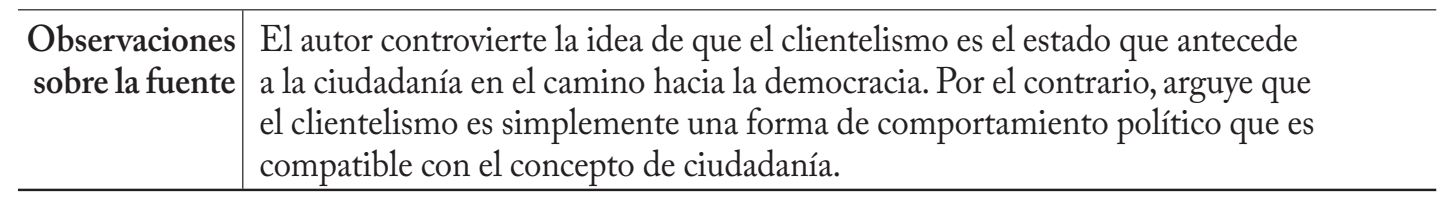

\begin{tabular}{r|l}
\hline Cita & $\begin{array}{l}\text { González, Fernán E. “Aproximación a la configuración política de Colombia”. } \\
\text { Controversia II (1989): 19-72. }\end{array}$ \\
\hline Año & 1989 \\
\hline $\begin{array}{r}\text { Enfoque } \\
\text { teórico }\end{array}$ & Socio-antropológico \\
enunciadas & Élites; dimensión simbólica del poder; democracia, modernidad y tradición. \\
\hline Hipótesis & $\begin{array}{l}\text { "Estas reformas, pensadas a veces como un intento de control de las burocracias } \\
\text { nacionales sobre las instancias regionales de poder e inspiradas frecuentemente } \\
\text { en realidades culturales y sociales muy diferentes de las nuestras, producen } \\
\text { normalmente el choque de dos lógicas: una 'modernizante'y otra 'tradicional'. } \\
\text { Estas lógicas contrapuestas tienden a neutralizarse mutuamente, produciéndose } \\
\text { una ineficaz omnipresencia del Estado, que algunos confunden con una hipertrofia } \\
\text { desmesurada del Estado que habría que intentar desmantelar en el mejor estilo } \\
\text { de Reagan y Thatcher. El Estado central tiene suficiente poder para entrabar las } \\
\text { iniciativas que parten de las regiones y localidades, pero carece de la fuerza necesaria } \\
\text { para tener una presencia eficaz en la periferia nacional (que comienza en los barrios } \\
\text { marginados de las grandes ciudades). Además, muchas de las reformas propuestas } \\
\text { por el Estado Central pasan por alto las idiosincrasias y las problemáticas específicas } \\
\text { de las regiones. Toda esta compleja situación se expresa en un divorcio entre el } \\
\text { discurso formal de políticos y tecnócratas, de corte moderno y liberal, y la práctica } \\
\text { política concreta, basada en las formas de la sociedad tradicional y en la perpetuación } \\
\text { de la desigualdad de oportunidades. Muchas de las prácticas clientelistas se } \\
\text { alimentan de ese divorcio". (p. 38). }\end{array}$ \\
\hline $\begin{array}{l}\text { Observaciones } \\
\text { sobre la fuente }\end{array}$ & $\begin{array}{l}\text { Artículo que argumenta la necesidad de empezar a hacer estudios de caso que } \\
\text { estudien la relación entre clientelismo y elección popular de alcaldes. }\end{array}$ \\
\hline
\end{tabular}

\begin{tabular}{r|l}
\hline Cita & $\begin{array}{l}\text { González, Fernán E. “Clientelismo y administración pública”. Enfoques colombianos } \\
(1980): 67-106 .\end{array}$ \\
\hline Año & 1980 \\
\hline $\begin{array}{r}\text { Enfoque } \\
\text { teórico }\end{array}$ & Socio-antropológico. \\
\hline $\begin{array}{r}\text { Categorías } \\
\text { enunciadas }\end{array}$ & Llerismo; turbayismo; lopismo; clientelismo tecnocrático; reforma de 1968. \\
\hline
\end{tabular}




\begin{tabular}{|c|c|}
\hline Hipótesis & $\begin{array}{l}\text { El ex presidente Lleras Restrepo plantea un debate contra el clientelismo, desde la } \\
\text { perspectiva de la democracia formal de tipo burgués, viéndolo como corruptela de } \\
\text { nuestro sistema democrático, como renacer del caciquismo tradicional, como rezago } \\
\text { de antiguas prácticas corruptas del quehacer político. Pero no cae en la cuenta de } \\
\text { que el clientelismo es la respuesta de la realidad social a una estructura institucional } \\
\text { formalmente democrática que oculta la dominación de los débiles a manos de los } \\
\text { poderosos. El clientelismo muestra que es imposible edificar una democracia real } \\
\text { sin ciertas bases mínimas de igualdad social y económica: "Una sociedad capaz de } \\
\text { otorgar servicios y seguridad a la inmensa mayoría de la población, necesariamente } \\
\text { está sujeta a los mecanismos clientelistas que otorgan esa seguridad y servicios a } \\
\text { cambio de apoyo político". }\end{array}$ \\
\hline $\begin{array}{l}\text { Observaciones } \\
\text { sobre la fuente }\end{array}$ & $\begin{array}{l}\text { Fernán González en este artículo aclara algunos elementos conceptuales que } \\
\text { Miranda Ontaneda menciona en algunos de sus textos, pero que no desarrolla } \\
\text { detalladamente. El texto parte de un análisis de clase, el cual se puede resumir } \\
\text { en cuestionarse a favor de quién funciona el sistema. A partir de esto, el autor } \\
\text { toma las denuncias hechas por el ex presidente Lleras Restrepo a propósito de los } \\
\text { manejos clientelistas de los políticos tradicionales para mostrar cómo este discurso } \\
\text { anticlientlista da origen a un nuevo fenómeno, cuyos protagonistas ya no son los } \\
\text { políticos tradicionales, sino los tecnócratas (este texto también está publicado en } \\
\text { Para leer la politica). }\end{array}$ \\
\hline
\end{tabular}

\begin{tabular}{r|l}
\hline Cita & $\begin{array}{l}\text { González Alcantud, José A. El Clientelismo Político. Perspectiva socioantropológica. } \\
\text { Barcelona: Anthropos Editorial, 1997. }\end{array}$ \\
\hline $\begin{array}{r}\text { Enfoque } \\
\text { teórico }\end{array}$ & Socio-antropológico \\
\hline $\begin{array}{r}\text { Categorías } \\
\text { enunciadas }\end{array}$ & Universal antropológico \\
\hline Hipótesis & $\begin{array}{l}\text { "Nuestra opinión última de que el clientelismo social y político constituye un } \\
\text { universal antropológico, no debe confundirse con la 'naturalidad'del clientelismo, } \\
\text { soportada en el sentido común circulante. La historia social de la humanidad no es } \\
\text { una estática providencialmente constituida, es una dinámica, donde la tensión moral } \\
\text { del hombre, de los hombres, por construir mundos ideales de igualdad es la apertura } \\
\text { utópica que evita la ruptura de la entropía social. Constatar la universalidad de un } \\
\text { problema, por tanto, supone sólo un paso teórico, para reconocer en el terreno de } \\
\text { las prácticas sociales, la necesidad de perseguir la igualdad real. Por eso la izquierda } \\
\text { política, social y cultural, a pesar de la debacle soviética, sigue existiendo, acaso solo } \\
\text { ya tras propuestas éticas, inarticuladas en el campo de la teoría". (p. 9) }\end{array}$ \\
\hline $\begin{array}{l}\text { Observaciones } \\
\text { sobre la fuente }\end{array}$ & $\begin{array}{l}\text { Se plantean las posturas del clientelismo: la derecha asume que el fenómeno es } \\
\text { la exacerbación del Homo bierarchicus del ser humano. Es decir, el clientelismo es } \\
\text { asumido como algo natural e inherente al orden social ya establecido. Por otro lado, } \\
\text { la izquierda, indignada por el estado de las relaciones jerárquicas establecidas por } \\
\text { el orden social, trata de corregir estos vicios de la sociedad diseñando propuestas } \\
\text { éticas ya inarticuladas, que se han desvirtuado en su propio ejercicio de la política. } \\
\text { El problema de estas dos posturas es que la explicación del fenómeno se da a a } \\
\text { partir de una sola variable o dimensión. A diferencia de lo anterior, desde una } \\
\text { perspectiva antropológica y sociológica, el clientelismo es un fenómeno que debe ser } \\
\text { abordado desde lo multidimensional en tanto que se configura como un universal } \\
\text { antropológico, dinámico, indisociable de algunas condiciones del ambiente y del } \\
\text { contexto, estructurante de un sistema social más grande. }\end{array}$ \\
\hline
\end{tabular}




\begin{tabular}{r|l}
\hline Cita & $\begin{array}{l}\text { González, Fernán E. Para leer la política: Ensayos de historia política colombiana. } \\
\text { Bogotá: Cinep, 1997. }\end{array}$ \\
\hline Año & 1997 \\
\hline $\begin{array}{r}\text { Enfoque } \\
\text { teórico }\end{array}$ & Socio-antropológico \\
\hline $\begin{array}{r}\text { Categorías } \\
\text { enunciadas }\end{array}$ & Bipartidismo \\
\hline Hipótesis & N.A \\
\hline $\begin{array}{r}\text { Observaciones } \\
\text { sobre la fuente }\end{array}$ & $\begin{array}{l}\text { Este libro es una compilación de artículos. El autor hace una propuesta que se } \\
\text { distancia de la historia tradicional, la cual solía centrarse en la formación del Estado } \\
\text { colombiano. Por el contrario, este análisis se centra en la vida política del país a } \\
\text { partir del proceso de formación de la sociedad: el bipartidismo se convierte en el } \\
\text { elemento articulador de las regiones y de las formas de acceso a la política nacional. }\end{array}$ \\
$\begin{array}{l}\text { El clientelismo se presenta bajo un análisis histórico donde la política se distancia de } \\
\text { las visiones moralizantes, donde los gamonales y los barones parroquiales adquieren } \\
\text { un papel fundamental en la articulación de los intereses regionales en la política } \\
\text { nacional. }\end{array}$ \\
\hline
\end{tabular}

\begin{tabular}{|c|c|}
\hline Cita & $\begin{array}{l}\text { Martz, John D. The Politics of Clientelism: Democracy \& the State in Colombia. New } \\
\text { Brunswick, New Jersey: Transaction Publishers, } 1997 .\end{array}$ \\
\hline Año & 1997 \\
\hline $\begin{array}{r}\text { Enfoque } \\
\text { teórico }\end{array}$ & Institucionalista \\
\hline $\begin{array}{r}\text { Categorías } \\
\text { enunciadas }\end{array}$ & $\begin{array}{l}\text { Feudalismo; la hacienda; precapitalismo, Frente Nacional; democracia excluyente; } \\
\text { clientelismo corporativo; violencia; narcotráfico; guerrillas. }\end{array}$ \\
\hline Hipótesis & $\begin{array}{l}\text { La hipótesis que sostiene John D. Martz es que el clientelismo que surgió en forma } \\
\text { tradicional en Colombia se ha modificado a través de un proceso de trasformación } \\
\text { de la sociedad en respuesta a los fenómenos de modernización. El funcionamiento } \\
\text { del clientelismo nació en el seno de formas tradicionalmente rurales que } \\
\text { propiciaron las relaciones patrón-cliente durante épocas feudales y coloniales. Con el } \\
\text { advenimiento de la urbanización, la tecnología y la burocratización del Estado en los } \\
\text { últimos años, el fenómeno clientelista ha sido reformado en un medio para expandir } \\
\text { y mantener el control político y social en condiciones de un centralismo burocrático. } \\
\text { En palabras del autor: "It will be argued that the clientelism that emerged in } \\
\text { traditional form has been modified through a process of evolutionary response to the } \\
\text { phenomena of modernization. The functioning of clientelism was embodied in the } \\
\text { traditionally rural and peasantry-based forms of patron-client relationships during } \\
\text { both feudal and patrimonial eras. With the advent of urbanization, technology, } \\
\text { and rampant statism in more recent years, the clientelistic phenomena has been } \\
\text { reshaped as a means of extending political and social controls under conditions of } \\
\text { bureaucratic centralism". (p.14) }\end{array}$ \\
\hline
\end{tabular}




\begin{tabular}{l|l}
\hline Observaciones & $\begin{array}{l}\text { Cuando hablamos de clientelismo, no podemos referirnos al fenómeno sin antes } \\
\text { sobre la fuente }\end{array}$ \\
hacer una arqueología del poder político en Colombia y en el resto del mundo. \\
Este análisis en primer instancia nos arroja a la comprensión de cómo las élites han \\
abordado el problema del orden y del poder político. El clientelismo se configura \\
como un elemento casi oblicuo que se genera en Colombia desde la colonia y el \\
predominio de la hacienda como institución reguladora en un territorio dado, dichas \\
relaciones que se establecen en el mundo rural entre patrones y clientes luego se \\
ven extrapoladas al ámbito de lo público cuando estas mismas élites encuentran \\
mecanismos de instauración y mantenimiento de su autoridad. El clientelismo \\
corporativo es el mecanismo que los partidos encuentran para generar las dinámicas \\
que se daban anteriormente en lo local, el Frente Nacional es una expresión de \\
las élites por generar dichas dinámicas, razón por la cual hoy en día encontramos \\
muchas constantes en las formas de reproducción del sistema político. Lo muy \\
interesante de este autor es que genera una relación causal entre el clientelismo y la \\
naturaleza excluyente del sistema político colombiano, razón por la cual no puede \\
dejar de relacionar otras variables típicas - del sistema colombiano- tales como la \\
violencia, la aparición de grupos insurgentes, el narcotráfico, relaciones de poder \\
jerárquicas, centralistas, concentradas en el ejecutivo y choques constantes con el \\
sistema democrático establecido.
\end{tabular}

\begin{tabular}{r|l}
\hline Cita & $\begin{array}{l}\text { González, Fernán E. “¿Colapso parcial o presencia diferenciada del Estado en } \\
\text { Colombia? Una mirada desde la historia”. Colombia Internacional (2003): 124-158. }\end{array}$ \\
\hline $\begin{array}{r}\text { Eño } \\
\text { teórico }\end{array}$ & 2003 \\
\hline $\begin{array}{r}\text { Categorías } \\
\text { enunciadas }\end{array}$ & Socio-antropológico \\
\hline Hipótesis & $\begin{array}{l}\text { "El contraste que hemos realizado entre la situación actual de crisis y una mirada } \\
\text { histórica de largo y mediano plazo nos sitúa muy lejos de una visión apocalíptica que } \\
\text { anuncia el inminente colapso de las instituciones democráticas y el régimen político } \\
\text { de Colombia. Sin embargo, el recorrido histórico que hemos mostrado nos muestra } \\
\text { una erosión gradual del modelo de mediación que el bipartidismo desarrollaba } \\
\text { entre la sociedad y el Estado colombianos y que permitió el funcionamiento de un } \\
\text { Estado que hacía presencia diferenciada según las situaciones regionales y locales } \\
\text { durante el siglo xix y buena parte del xx. Esa erosión no es necesariamente negativa, } \\
\text { pues puede significar una oportunidad para una más profunda democratización } \\
\text { de la nación, si se lograra un acercamiento menos negativo a la realidad política } \\
\text { concreta para introducir las reformas políticas necesarias para esa democratización. } \\
\text { Esa democratización pasa por la recuperación de la dimensión de la política como } \\
\text { construcción colectiva de nación, que tiene dimensiones culturales, sociales y } \\
\text { económicas". (p.152) }\end{array}$ \\
\hline $\begin{array}{l}\text { Observaciones } \\
\text { sobre la fuente }\end{array}$ & $\begin{array}{l}\text { El problema de la viabilidad de la democracia puede abordarse, según Fernán } \\
\text { González, desde tres perspectivas: la primera, desde una perspectiva de una } \\
\text { democracia ideal y abstracta; la segunda, desde una postura melancólica donde el } \\
\text { Estado moderno ha perdido el monopolio de la fuerza sobre su territorio y el control } \\
\text { sobre sus instituciones; la tercera es donde se habla de la construcción diaria y } \\
\text { paulatina del Estado, de su poder territorial y de la consolidación de las instituciones. } \\
\text { El autor basa su propuesta en las teorías de construcción del Estado de Charles Tilly. }\end{array}$ \\
\hline
\end{tabular}




\begin{tabular}{r|l}
\hline Cita & $\begin{array}{l}\text { González, Fernán. E. "Aportes al diálogo entre historia y ciencia política. Una } \\
\text { contribución desde la experiencia investigativa en el Cinep”. Historia Crítica (2004): } \\
23-38 .\end{array}$ \\
\hline $\begin{array}{r}\text { Enfoque } \\
\text { teórico }\end{array}$ & Soch \\
\hline $\begin{array}{r}\text { Categorías } \\
\text { enunciadas }\end{array}$ & $\begin{array}{l}\text { Malentendidos fundamentales; Iglesia católica y el Partido Liberal; clientelistas y } \\
\text { tecnócratas; causas objetivas y subjetivas de la violencia; Cinep. }\end{array}$ \\
\hline Hipótesis & $\begin{aligned} \text { "En ese sentido, lo que he tratado de hacer es indagar por los trasfondos históricos } \\
\text { de nuestros problemas políticos: intentar responder, desde una relectura de la } \\
\text { historia política ampliamente considerada, a las preguntas que se hace la Ciencia } \\
\text { Política sobre las actuales violencias, el clientelismo y la corrupción, la crisis de } \\
\text { representación política, las relaciones entre Estado y sociedad, e iglesia católica y } \\
\text { estado liberal, el tipo de presencia del Estado en las diversas regiones, etc.". (p. 24) }\end{aligned}$ \\
\hline $\begin{array}{r}\text { Observaciones } \\
\text { sobre la fuente }\end{array}$ & $\begin{array}{l}\text { Es un artículo que hace una revisión en retrospectiva de los temas estudiados por } \\
\text { el Cinep. Se configura como un texto valioso para este estado del arte en la medida } \\
\text { en que narra los primeros acercamientos al tema en Colombia; describe brevemente } \\
\text { el enfoque inicial; y enlista una serie de autores nacionales e internacionales que } \\
\text { hicieron contribuciones al estudio del fenómeno. Fernán González se caracteriza } \\
\text { por marcar una visión diferenciada de los fenómenos, en este texto resalta la postura } \\
\text { de Fernando Escalante, ante el cual considera: "Estas perspectivas permiten leer de } \\
\text { manera más dinámica el papel del clientelismo como articulador de sociabilidades } \\
\text { tradicionales y modernas para hacer presentes a los aparatos del Estado moderno en } \\
\text { condiciones sociales que no permiten su dominio directo". (p. 34) }\end{array}$ \\
\hline
\end{tabular}

\begin{tabular}{r|l}
\hline Cita & $\begin{array}{l}\text { Morales Benítez, Otto. “Clientelismo y corrupción”. En Carlos Lleras Restrepo, } \\
\text { compilado por Otto Morales Benítez,113-172. Santafé de Bogotá: Universidad } \\
\text { Central, 1999. }\end{array}$ \\
\hline $\begin{array}{r}\text { Eño } \\
\text { teórico }\end{array}$ & 1999 \\
\hline $\begin{array}{r}\text { Categorías } \\
\text { enunciadas }\end{array}$ & Institucionalista \\
\hline Hipótesis & $\begin{array}{l}\text { Como compilación de artículos periodísticos del ex presidente Carlos Lleras } \\
\text { Restrepo no maneja hipótesis, pero expresa abiertamente una forma de concebir el } \\
\text { fenómeno clientelista como el peor de los vicios del sistema político colombiano. }\end{array}$ \\
\hline $\begin{array}{r}\text { Observaciones } \\
\text { sobre la fuente }\end{array}$ & $\begin{array}{l}\text { Este libro es una recopilación de artículos publicados en el diario Nueva Frontera. } \\
\text { El libro trata sobre los principales aportes del ex presidente Carlos Lleras Restrepo } \\
\text { en los campos del periodismo, del clientelismo y la corrupción y la modernización } \\
\text { del país. La mayoría de artículos abordan el tema de la corrupción administrativa; } \\
\text { y ponen en tema de discusión algunos aspectos que eran relevantes para las élites } \\
\text { políticas de la época, por ejemplo, el hecho de que la elección popular de alcaldes } \\
\text { fuera un motín para los políticos clientelistas. En general, a pesar de hacer una } \\
\text { distinción entre corrupción y clientelismo, los artículos abordan el fenómeno como } \\
\text { el principal vicio de la política colombiana. }\end{array}$ \\
\hline
\end{tabular}




\begin{tabular}{r|l}
\hline Cita & $\begin{array}{l}\text { Gutiérrez Sanín, Francisco y Andrés Dávila Ladrón de Guevara. "Paleontólogos } \\
\text { o politólogos: ¿Qué podemos decir hoy sobre los dinosaurios?" Revista de Estudios } \\
\text { Sociales (2000):39-49. }\end{array}$ \\
\hline $\begin{array}{r}\text { Enfoque } \\
\text { teórico }\end{array}$ & 2000 \\
\hline $\begin{array}{r}\text { Categorías } \\
\text { enunciadas }\end{array}$ & $\begin{array}{l}\text { Institucionalista } \\
\text { bienes públicos; bipartidismo; especificidad colombiana. }\end{array}$ \\
\hline Hipótesis & $\begin{array}{l}\text { "Gracias a los trabajos históricos y sociológicos que se han producido en los últimos } \\
\text { veinte años, sabemos aproximadamente cómo funciona el clientelismo colombiano } \\
\text { (sobre todo el rural; contamos con muchos menos trabajos sobre la vertiente } \\
\text { urbana), pero en cambio tenemos poco o nada que decir sobre los mecanismos } \\
\text { que lo hacen a la vez 'anacrónico' y 'vital'. Es decir, la 'descripción densa', con todo } \\
\text { lo que ha aportado, no ha podido hasta el momento aprehender los mecanismos } \\
\text { que explicarían la sorprendente supervivencia -quizás crecimiento- de las fuerzas } \\
\text { clientelistas en Colombia”. (p. 39) }\end{array}$ \\
\hline $\begin{array}{l}\text { Observaciones } \\
\text { sobre la fuente }\end{array}$ & $\begin{array}{l}\text { Durante las últimas décadas del siglo xx los estudios sobre el fenómeno } \\
\text { del clientelismo en Colombia, la mayoría de ellos basados en perspectivas } \\
\text { históricas y socio-antropológicas, han contribuido a descifrar los mecanismos de } \\
\text { funcionamiento del mismo, sobre todo en el área rural. Sin embargo, dichos estudios } \\
\text { hasta ahora se muestran insuficientes para demostrar por qué el fenómeno presenta } \\
\text { rasgos de ser anacrónico y vital al mismo tiempo. Cómo o por qué el fenómeno } \\
\text { pervive, se reproduce y muestra tener síntomas de fortalecimiento son algunas de las } \\
\text { preguntas que se plantea Francisco Gutiérrez. }\end{array}$ \\
\hline
\end{tabular}

\begin{tabular}{|c|c|}
\hline Cita & $\begin{array}{l}\text { Gutiérrez Sanín, Francisco. "Clientelismo y sus enredos". En La ciudad representada: } \\
\text { política y conflicto en Bogotá, 55-120. Bogotá: тм Editores, } 1998 .\end{array}$ \\
\hline Año & 1998 \\
\hline $\begin{array}{r}\text { Enfoque } \\
\text { teórico }\end{array}$ & Institucionalista \\
\hline $\begin{array}{r}\text { Categorías } \\
\text { enunciadas }\end{array}$ & Clientelismo en Bogotá; juntas de Acción Comunal; participación y representación. \\
\hline Hipótesis & $\begin{array}{l}\text { ‘El segundo capítulo está dedicado a 'los enredos del clientelismo'. Una cosas es } \\
\text { decir que una reflexión sobre las JAC nos da claves de explicación invaluables para } \\
\text { entender las especificidades de nuestra vida participativa, otra es adoptar una actitud } \\
\text { inocente, en el sentido peyorativo, frente a ellas. No es un gran secreto que las JAC } \\
\text { son un nicho valiosísimo para el clientelismo. Pero esto plantea por lo menos dos } \\
\text { preguntas incomódas. ¿Por qué es tan poderoso y flexible el clientelismo? Pues no } \\
\text { solo se apoderó de las JAc en el pasado, sino que también hoy tiene una presencia } \\
\text { sustancial en las Juntas Administradores Locales, y en múltiples instancias que, se } \\
\text { suponía, eran democráticas por excelencia y, por consiguiente, esterilizadoras de } \\
\text { prácticas perversas. Además, las disposiciones constitucionales y las decisiones de los } \\
\text { gobiernos distritales (los de Mockus y Bromberg, pero también el de Castro) contra } \\
\text { el clientelismo lo hubieran debido debilitar bastante. Y si logramos contestar a la } \\
\text { primera pregunta, todavía nos queda otra: ¿Cómo funciona el clientelismo en una } \\
\text { ciudad de seis millones de habitantes? ¿En qué se diferencia de lo que hacen, por } \\
\text { ejemplo, los gamonales rurales? Apenas nos salimos así sea un poco del ámbito de las } \\
\text { generalidades cómodas, nos vamos dando cuenta de que sabemos muy poco sobre el } \\
\text { funcionamiento del clientelismo en una gran metrópoli, de qué manera se entronca }\end{array}$ \\
\hline
\end{tabular}




\begin{tabular}{l|l}
\hline & $\begin{array}{l}\text { con el sistema de partidos y el mundo de lo político institucional, qué intereses, } \\
\text { expectativas y anhelos logra representar".(p.11) }\end{array}$ \\
\hline $\begin{array}{l}\text { Observaciones } \\
\text { sobre la fuente }\end{array}$ & $\begin{array}{l}\text { Gutiérrez toma a Bogotá como unidad de análisis central de su investigación. } \\
\text { Su discusión tiene un anclaje en el terreno a la cultura al relacionar el fenómeno } \\
\text { clientelista con: formas de tramitar intereses, formas de participación, representación } \\
\text { y formación de ciudadanía. Para Gutiérrez el clientelismo es un fenómeno que } \\
\text { en mucho casos complementa dinámicas democráticas propias de territorios } \\
\text { colombianos. }\end{array}$ \\
\hline
\end{tabular}

\begin{tabular}{|c|c|}
\hline Cita & $\begin{array}{l}\text { Losada Lora, Rodrigo. Clientelismo y elecciones: tres modelos explicativos del } \\
\text { comportamiento electoral colombiano. Bogotá: Pontificia Universidad Javeriana, } 1984 .\end{array}$ \\
\hline Año & 1984 \\
\hline $\begin{array}{r}\text { Enfoque } \\
\text { teórico }\end{array}$ & Institucionalista \\
\hline $\begin{array}{r}\text { Categorías } \\
\text { enunciadas }\end{array}$ & $\begin{array}{l}\text { Enfoque psico-social; votante racional y votante clientelista; comportamiento } \\
\text { electoral. }\end{array}$ \\
\hline Hipótesis & $\begin{array}{l}\text { "El estudio se basa fundamentalmente en una serie de } 317 \text { encuestas, hechas } \\
\text { en cuatro localidades, dos de ellas urbanas (los barrios Minuto de Dios y Diana } \\
\text { Turbay, de Bogotá) y dos rurales (los municipios de Tabio y Fómeque). Estos sitios } \\
\text { fueron escogidos con el criterio de que constituyen casos cruciales para los tres } \\
\text { modelos en cuestión [modelo psico-social, modelo del votante racional y modelo } \\
\text { del votante clientelista]. Por un lado, dos de ellos (Fómeque y el barrio Diana } \\
\text { Turbay) sobresalen, tal como se documentará en los dos próximos capítulos, por } \\
\text { la abundancia de las interacciones clientelistas. En contraposición, las otras dos } \\
\text { localidades conocen muy poco de clientelismo". (p. 13) }\end{array}$ \\
\hline $\begin{array}{c}\text { Observaciones } \\
\text { sobre la fuente }\end{array}$ & $\begin{array}{l}\text { Bajo los modelos psico-social, racional y de clientelismo, el autor busca comprender } \\
\text { el comportamiento electoral de los colombianos. Para ello, la investigación } \\
\text { es planteada como un estudio de caso aplicado a dos barrios de Bogotá y dos } \\
\text { municipios. Las variables que se pretenden analizar son las de votante racional y } \\
\text { votante clientelista. Para ello, el autor construye un marco teórico sobre clientelismo, } \\
\text { tomando los autores que hasta ese año se habían caracterizado por hacer aportes } \\
\text { teóricos a la materia, entre ellos se encuentran: Scott, Powell, Lemarchand, Legg, } \\
\text { Kauffman, Boissevain, Médard, Landé, Foster, Wolf, Eisenstadt y Roniger, Key, } \\
\text { Gosnell,y Bolch. Esta investigación también tiene pretensiones metodológicas en } \\
\text { tanto busca generar un modelo que permita superar el enfoque psico-social, sin } \\
\text { embargo no lo logra. Hay algunos errores en el tamaño de la muestra que el mismo } \\
\text { autor reconoce. Finalmente se logra concluir que el clientelismo no tiene una } \\
\text { incidencia directa sobre la elección del votante. Sin embargo, abre la duda sobre los } \\
\text { efectos indirectos del clientelismo en otros campos y variables. }\end{array}$ \\
\hline
\end{tabular}

\begin{tabular}{r|l}
\hline Cita & $\begin{array}{l}\text { Gutiérrez Sanín, Francisco. "Historia de democratización anómala: el partido } \\
\text { Liberal en el sistema político colombiano desde el Frente Nacional hasta hoy". } \\
\text { En Degradación o cambio: evolución del sistema político colombiano, compilado por } \\
\text { Francisco Gutiérrez Sanín, 25-78, Bogotá: Editorial Norma, 2002. }\end{array}$ \\
\hline Año & 2002 \\
\hline $\begin{array}{r}\text { Enfoque } \\
\text { teórico }\end{array}$ & Institucionalista \\
\hline
\end{tabular}




\begin{tabular}{r|l}
\hline $\begin{array}{r}\text { Categorias } \\
\text { enunciadas }\end{array}$ & Participación, partido Liberal; Constitución de 1991; clientelismo; democratización. \\
\hline Hipótesis & $\begin{array}{l}\text { "La evolución del 'partido agárralo-todo con matices reformistas'a a partido de masas } \\
\text { poco denso' nos pone frente a la triste historia de una democratización con deterioro. } \\
\text { A medida que el partido se hizo más incluyente, resultó más inadecuado para } \\
\text { tramitar demandas populares a nivel macro e incluso para mantenerse dentro de la } \\
\text { legalidad. Uno de los resultados más perversos de tal desenlace es que cantidad de } \\
\text { demagogos y nostálgicos pueden vociferar contra la democratización mostrando las } \\
\text { evidencias palpables del deterioro". (p. 73-74) }\end{array}$ \\
\hline $\begin{array}{l}\text { Observaciones } \\
\text { sobre la fuente }\end{array}$ & $\begin{array}{l}\text { En esta oportunidad Gutiérrez Sanín se pregunta por la evolución del Partido } \\
\text { Liberal: i) se interroga por su existencia después de la Constitución de 1991 y por la } \\
\text { transformación en su forma de operar; ii) utiliza una metodología cualitativa; yiii) } \\
\text { concluye que el Partido Liberal existe, sin embargo se ha transformado, de manera } \\
\text { que al convertirse en un partido más incluyente, se ha expandido restando poder } \\
\text { a sus centros. La mejor forma para definirlo es: un partido grande en extensión } \\
\text { pero poco denso. Según el autor, este fue el precio que los partidos tradicionales } \\
\text { pagaron por la democratización del sistema. Se plantea adicionalmente que, con } \\
\text { la Constitución política de 1991, el fenómeno clientelista fue observado como } \\
\text { categoría analítica, espacio articulador de mecanismos de participación ciudadana y } \\
\text { no solamente en tono peyorativo, como un juicio o un insulto hacia el obrar político. }\end{array}$ \\
\hline
\end{tabular}

\begin{tabular}{r|l}
\hline Cita & $\begin{array}{l}\text { Jaramillo G., Nicolás J. “Clientelismo y Poder. Cambios en las relaciones clientelistas } \\
\text { en Colombia (1960-1990)”. Tesis de pregrado. Universidad Nacional, Bogotá, 2003. }\end{array}$ \\
\hline Año & 2003 \\
\hline $\begin{array}{r}\text { Enfoque } \\
\text { teórico }\end{array}$ & Institucionalista \\
\hline $\begin{array}{r}\text { Categorías } \\
\text { enunciadas }\end{array}$ & Monografía de grado \\
\hline Hipótesis & $\begin{array}{l}\text { El autor se pregunta: ¿Cómo funciona el clientelismo cuando el objeto del } \\
\text { intercambio es el voto? }\end{array}$ \\
\hline $\begin{array}{r}\text { Observaciones } \\
\text { sobre la fuente }\end{array}$ & $\begin{array}{l}\text { Es una tesis de pregrado de la Universidad Nacional, insumo fundamental para la } \\
\text { publicación de un texto que se configuró como un texto cercano a la tipología de } \\
\text { estado del arte sobre clientelismo en Colombia. }\end{array}$ \\
\hline
\end{tabular}

\begin{tabular}{r|l}
\hline Cita & $\begin{array}{l}\text { González Hernández, Carlos José. “La cofinanciación en Colombia: una empresa más } \\
\text { del clientelismo político”. Tesis de pregrado. Universidad de los Andes, Bogotá, 2001. }\end{array}$ \\
\hline Año & 2001 \\
\hline $\begin{array}{r}\text { Enfoque } \\
\text { teórico }\end{array}$ & Estructural-funcionalista \\
\hline $\begin{array}{r}\text { Categorías } \\
\text { enunciadas }\end{array}$ & Cofinanciación; auxilios parlamentarios; Constitución de 1991; descentralización. \\
\hline
\end{tabular}




\begin{tabular}{c|l}
\hline Hipótesis & $\begin{array}{c}\text { "Pese a que la cofinanciación, en el marco del proceso de descentralización, fue } \\
\text { concebida, diseñada y estructurada como una herramienta idónea y trasparente } \\
\text { de coordinación y apoyo financiero y técnico del gobierno central a entidades } \\
\text { territoriales, el sistema político, y en particular su marcada connotación clientelista, } \\
\text { la pervirtieron al convertirla en una pieza más de la relación clientelista entre el } \\
\text { Gobierno Nacional y el Congreso de la Republica, por un lado, y los congresistas } \\
\text { y sus electores por el otro. En este sentido, la cofinanciación se transformó en un } \\
\text { incentivo efectivo en la cadena de reproducción clientelista y, por ende, en elemento } \\
\text { funcional del sistema político". }\end{array}$ \\
\hline Observaciones & $\begin{array}{l}\text { La Constitución política de 1991 trajo consigo algunas medidas que abogaban por } \\
\text { sobre la fuente }\end{array}$ \\
& $\begin{array}{l}\text { la modernización fiscal, política y administrativa del país, al mismo tiempo que se } \\
\text { avanzaba en fortalecer el régimen democrático. Dichas medidas no solo trataban de } \\
\text { corregir algunas prácticas políticas tradicionales, sino también erradicarlas. Una de } \\
\text { las medidas más atacadas fue lo que se conoce como los auxilios parlamentarios. Sin } \\
\text { embargo, al eliminarlos, el mismo sistema buscaría más tarde nuevos mecanismos } \\
\text { para remplazarlos. Este mecanismo fue posteriormente conocido como los “fondos de } \\
\text { cofinanciación". Dichos fondos serían utilizados por los congresistas y sus clientelas, } \\
\text { pero también desde el ejecutivo hacia los cuerpos colegiados de elección popular. }\end{array}$ \\
\hline
\end{tabular}

\begin{tabular}{|c|c|}
\hline Cita & $\begin{array}{l}\text { Pizano Rojas, Lariza. "Caudillismo y clientelismo: expresiones de una misma lógica. } \\
\text { El fracaso del modelo liberal de Latinoamérica". Revista de Estudios Sociales (2001): } \\
\text { 75-83. }\end{array}$ \\
\hline Año & 2001 \\
\hline $\begin{array}{r}\text { Enfoque } \\
\text { teórico }\end{array}$ & Institucionalista \\
\hline $\begin{array}{r}\text { Categorías } \\
\text { enunciadas }\end{array}$ & $\begin{array}{l}\text { Siglo xIx; revoluciones liberales; democracia; instituciones informarles y formales; } \\
\text { centralismo; caciquismo; clientelismo; México. }\end{array}$ \\
\hline Hipótesis & $\begin{array}{l}\text { "El siglo xix y sus principales actores encarnan una combinación de prácticas } \\
\text { políticas coloniales ligadas al prestigio y al poder personal, con ideales y } \\
\text { justificaciones propias de un contexto independentista. Además, el inconmensurable } \\
\text { regionalismo, institucionalmente reforzado durante la colonia, no permitió ni } \\
\text { siquiera que las guerras de independencia abrieran paso en los diferentes territorios } \\
\text { latinoamericanos, a Barones Mayores, capaces de promover una homogeneización } \\
\text { por vía impositiva"(p. 78). }\end{array}$ \\
\hline $\begin{array}{c}\text { Observaciones } \\
\text { sobre la fuente }\end{array}$ & $\begin{array}{l}\text { Larisa Pizano hace un análisis de las relaciones de poder del xix en Latinoamérica } \\
\text { para encontrar algunas continuidades entre la institucionalidad de la época y la de } \\
\text { nuestros días. Lo anterior debido a que los principios liberales de la época se vieron } \\
\text { influenciados por algunas instituciones coloniales tales como la encomienda, la } \\
\text { hacienda; algunos actores como los caudillos; y las relaciones de intercambio que } \\
\text { estos mismos establecían a través de mecanismos clientelistas. Este estudio parte de } \\
\text { un análisis general sobre los procesos independentistas de Latinoamérica, para luego } \\
\text { producir conclusiones mucho más concretas sobre México. }\end{array}$ \\
\hline
\end{tabular}

\begin{tabular}{r|l}
\hline Cita & $\begin{array}{l}\text { Sandquist Restrepo, Erik. “Clientelismo, descentralización y Fondo de } \\
\text { Cofinanciación”. Tesis de pregrado, Universidad de los Andes, Bogotá, 2001. }\end{array}$ \\
\hline Año & 2001 \\
\hline $\begin{array}{r}\text { Enfoque } \\
\text { teórico }\end{array}$ & Institucionalista \\
\hline
\end{tabular}




\begin{tabular}{r|l}
\hline $\begin{array}{r}\text { Categorías } \\
\text { enunciadas }\end{array}$ & Fondos de cofinanciación \\
\hline Hipótesis & $\begin{array}{l}\text { "La distribución de los recursos provenientes de los Fondos de Cofinanciación, } \\
\text { fundamentales para facilitar el proceso de descentralización, fueron distribuidos con } \\
\text { criterios eminentemente clientelistas, afianzando el ejercicio de la intermediación } \\
\text { propio de este fenómeno político". }\end{array}$ \\
\hline $\begin{array}{l}\text { Observaciones } \\
\text { sobre la fuente }\end{array}$ & $\begin{array}{l}\text { Es una tesis de pregrado de la Universidad del Los Andes que indaga sobre los } \\
\text { fondos de cofinanciación. Su conclusión es que estos fueron parte de la repartición } \\
\text { de las clientelas. }\end{array}$ \\
\hline
\end{tabular}

\begin{tabular}{r|l}
\hline Cita & $\begin{array}{l}\text { Jaramillo, Nicolás. Clientelismo y poder: relectura crítica de algunas reflexiones hechas } \\
\text { sobre el clientelismo en Colombia. Bogotá: Universidad Nacional de Colombia, } \\
\text { Facultad de Derecho, Ciencias Políticas y Sociales, 2005. }\end{array}$ \\
\hline $\begin{array}{r}\text { Año } \\
\text { teórico }\end{array}$ & 2005 \\
\hline $\begin{array}{r}\text { Categorías } \\
\text { enunciadas }\end{array}$ & Institucionalista \\
\hline Hipótesis & N.A del arte \\
\hline $\begin{array}{r}\text { Observaciones } \\
\text { sobre la fuente }\end{array}$ & $\begin{array}{l}\text { El autor plantea que la dimensión del poder no ha sido completamente estudiada } \\
\text { y que de la comprensión de dicho factor se podría obtener a partir de una mayor } \\
\text { claridad sobre las formas de operación del fenómeno clientelista en Colombia. Se } \\
\text { propone un estudio basado en elementos funcionales, estructurales e institucionales } \\
\text { del fenómeno. Es un texto que expone los principales logros de las obras más } \\
\text { representativas de la materia en Colombia, es un texto cercano a un estado del arte. }\end{array}$ \\
\hline
\end{tabular}

\begin{tabular}{r|l}
\hline Cita & $\begin{array}{l}\text { Escobar, Cristina. “Clientelismo y ciudadanía: los límites de las reformas } \\
\text { democráticas en el departamento de Sucre". Análisis Político (2002):36-54. }\end{array}$ \\
\hline Año & 2002 \\
\hline $\begin{array}{r}\text { Enfoque } \\
\text { teórico }\end{array}$ & Marxista \\
enunciadas & $\begin{array}{l}\text { No-ciudadanía; clientelismo de resistencia; violencia; cultura política; movimientos } \\
\text { campesinos. }\end{array}$ \\
\hline Hipótesis & $\begin{array}{l}\text { "Un análisis de la participación política en el departamento de Sucre muestra } \\
\text { que el clientelismo, que está tan ampliamente extendido en las democracias } \\
\text { latinoamericanas, detiene el poder de los grupos populares organizados bajo nuevas } \\
\text { reglas políticas, y frustra la promesa de un cambio institucional. Primero, una } \\
\text { precaria situación económica fuerza a importantes sectores de la población a valorar } \\
\text { los beneficios inmediatos de cambiar sus votos, sobre los beneficios abstractos y a } \\
\text { largo plazo de la representación política. Segundo, la larga historia de estas prácticas } \\
\text { políticas ha creado instituciones informales basadas en redes de intercambio } \\
\text { desigual y ha prevenido el desarrollo de instituciones locales de participación que } \\
\text { podrían servir como base para la ciudadanía democrática. Tercero, los políticos y sus } \\
\text { maquinarias han mostrado una mayor habilidad para adaptarse a los cambios en las } \\
\text { reglas políticas y en las instituciones de lo que los proponentes de reformas políticas } \\
\text { institucionales generalmente anticipaban”. (p. 36) }\end{array}$ \\
\hline
\end{tabular}




\begin{tabular}{l|l}
\hline $\begin{array}{l}\text { Observaciones } \\
\text { sobre la fuente }\end{array}$ & $\begin{array}{l}\text { Cristina Escobar plantea que el clientelismo puede ser visto como un mecanismo de } \\
\text { resistencia, en tanto que los clientes han dejado de ser considerados como súbditos } \\
\text { dominados para pasar a constituirse como un grupo organizado con conciencia de } \\
\text { clase que encuentra en este modelo asociativo del clientelismo mecanismos para } \\
\text { obtener beneficios. Sin embargo la cultura del clientelismo político es contradictoria } \\
\text { a la cultura de la ciudadanía ya que los no-ciudadanos (es decir, los clientes de } \\
\text { las relaciones clientelistas) han entregado sus derechos sociales y políticos ante }\end{array}$ \\
& $\begin{array}{l}\text { la imposibilidad de obtenerlos por los medios institucionales. Las reformas } \\
\text { institucionales que empezaron en 1988, si bien son fundamentales para poner en } \\
\text { práctica mecanismos de participación política, no son suficientes para asegurarla en } \\
\text { su totalidad, ya que existen limitantes como la violencia, la desigualdad, la falta de } \\
\text { acceso a la información y niveles óptimos de educación de la población civil. En otros } \\
\text { términos, el clientelismo frustró el proyecto de convertir las movilizaciones campesinas } \\
\text { relativamente exitosas en una fuerza electoral significativa, una vez que las reformas } \\
\text { políticas crearon una oportunidad de participación de nuevas fuerzas políticas. }\end{array}$ \\
\hline
\end{tabular}

\begin{tabular}{|c|c|}
\hline Cita & $\begin{array}{l}\text { García Sánchez, Miguel. "La política bogotana, un espacio de recomposición (1982- } \\
\text { 2001)". En Degradación o cambio: evolución del sistema político colombiano, compilado } \\
\text { por Francisco Gutiérrez Sanín, 183-220. Bogotá: Editorial Norma, 2002. }\end{array}$ \\
\hline Año & 2002 \\
\hline $\begin{array}{r}\text { Enfoque } \\
\text { teórico }\end{array}$ & Institucionalista \\
\hline $\begin{array}{r}\text { Categorías } \\
\text { enunciadas }\end{array}$ & $\begin{array}{l}\text { Intermediación; clientelismo moderno; redes; concejales; ediles; representación; } \\
\text { Bogotá; intermediación. }\end{array}$ \\
\hline Hipótesis & $\begin{array}{l}\text { “De manera muy sintética, se puede señalar que lo que sufren los esquemas de } \\
\text { intermediación política en Bogotá es el paso de un clientelismo 'moderno', hacia } \\
\text { lo que autores como Gutiérrez y Dávila han denominado el 'clientelismo de } \\
\text { mercado'. Este, aunque sigue dependiendo de los recursos del Estado, se caracteriza } \\
\text { por la ruptura del esquema de articulación piramidal conformado por un patrón } \\
\text { y unos intermediarios quienes a su vez se vinculan con el electorado; aśí,'El } \\
\text { Patrón sistemáticamente va perdiendo poder a manos de su séquito inmediato de } \\
\text { seguidores, y estos, por su parte, se van debilitando frente a los lideres barriales'o } \\
\text { locales (Gutiérrez,1998:103). De esta forma tienen lugar una fragmentación o } \\
\text { ruptura de la red clientelista, que supone el resquebrajamiento de las lealtades entre } \\
\text { políticos y la emergencia de una competencia más intensa entre ellos, las redes son } \\
\text { más pequeñas y tienen, en el caso de Bogotá, como centro a concejales y ediles. La } \\
\text { realidad del clientelismo bogotano es la de las múltiples negociaciones entre ediles y } \\
\text { concejales y entre ciudadanos políticos de los distintos niveles de representación. Sin } \\
\text { exagerar, es posible señalar que durante los } 90 \text {, en Bogotá, se acabaron los grandes } \\
\text { caciques”. (p. 200) }\end{array}$ \\
\hline $\begin{array}{c}\text { Observaciones } \\
\text { sobre la fuente }\end{array}$ & $\begin{array}{l}\text { Las transformaciones de la política bogotana a lo largo de los últimos } 20 \text { años, como } \\
\text { resultado de las dinámicas impresas por las interacciones entre la juntas de Acción } \\
\text { Comunal, el Concejo y la Alcaldía, imprimieron un carácter propio a la política } \\
\text { capitalina. A partir de estas transformaciones, fue posible observar: clientelismo, } \\
\text { nuevas dinámicas entre los partidos políticos y un cambio profundo en el sistema } \\
\text { electoral. }\end{array}$ \\
\hline
\end{tabular}




\begin{tabular}{r|l}
\hline Cita & $\begin{array}{l}\text { Leal Buitrago, Francisco. "El sistema político del clientelismo”. Análisis Político, } \\
(2003): 63-140 .\end{array}$ \\
\hline Año & 2003 \\
\hline $\begin{array}{r}\text { Enfoque } \\
\text { teórico }\end{array}$ & Estructural-funcionalista \\
\hline $\begin{array}{r}\text { Categorías } \\
\text { enunciadas }\end{array}$ & N.A \\
\hline Hipótesis & N.A \\
\hline $\begin{array}{r}\text { Observaciones } \\
\text { sobre la fuente }\end{array}$ & $\begin{array}{l}\text { Es un artículo publicado en la revista Análisis Político que condensa los } \\
\text { planteamientos de la investigación realizada en conjunto con Andrés Dávila Ladrón } \\
\text { de Guevara. }\end{array}$ \\
\hline
\end{tabular}

\begin{tabular}{|c|c|}
\hline Cita & $\begin{array}{l}\text { Meneses, Lucía Eugenia. "La política Nasa y el clientelismo en el municipio de Páez, } \\
\text { Cauca". Revista Colombiana de Antropología e Historia } 38 \text { (2002): 105-130. }\end{array}$ \\
\hline Año & 2002 \\
\hline $\begin{array}{r}\text { Enfoque } \\
\text { teórico }\end{array}$ & Socio-antropológico \\
\hline \begin{tabular}{r|r} 
Categorías \\
enunciadas
\end{tabular} & Clientelismo e indígenas; forma de hacer política; contexto social y cultural. \\
\hline Hipótesis & $\begin{array}{l}\text { "Este artículo se orienta en tal sentido, al presentar las diversas formas de } \\
\text { hacer política que se generaron en el territorio administrativo Páez a raíz de la } \\
\text { institucionalización del movimiento político Nasa y del acceso al poder por parte de } \\
\text { sus líderes, resaltando los cambios y las persistencias sociales en la manera de hacer } \\
\text { política, de acuerdo con el contexto social y cultural. En el caso analizado se resalta } \\
\text { cómo después de expedida la Constitución Política de } 1991 \text { y, específicamente, a } \\
\text { partir de las transferencias de recursos del estado central a los resguardos indígenas } \\
\text { del municipio de Páez, comenzaron a constituirse redes clientelistas, basadas } \\
\text { en las posiciones de poder que empezaron a desempeñar algunos líderes en las } \\
\text { organizaciones indígenas. Estas redes de clientela, sin embargo, no constituyen un } \\
\text { sistema idéntico al de los partidos políticos tradicionales; se trata, quizá, de una } \\
\text { variación o de un sistema particular que se compagina como una nueva forma del } \\
\text { ejercicio de la política local. No obstante, el proyecto indígena Nasa persiste en } \\
\text { reivindicar la identidad política étnica". }\end{array}$ \\
\hline $\begin{array}{l}\text { Observaciones } \\
\text { sobre la fuente }\end{array}$ & $\begin{array}{l}\text { La autora sostiene que hacen falta estudios que indaguen por las formas particulares } \\
\text { del quehacer de la política en Colombia. En un esfuerzo por cubrir este vacío de } \\
\text { investigación, este artículo sustenta que las reformas en términos de participación } \\
\text { política de grupos étnicos minoritarios establecidas con la Constitución de } 1991 \\
\text { dieron inicio a redes clientelistas sustentadas en las posiciones de poder de algunos } \\
\text { líderes de las organizaciones indígenas. Estas redes clientelistas no son comparables } \\
\text { con las viejas formas de operación de los partidos políticos tradicionales. Por el } \\
\text { contrario, estas nuevas dinámicas exhiben rasgos propios al ejercicio del poder en } \\
\text { el municipio. El clientelismo es visto acá como una nueva forma del ejercicio de la } \\
\text { política local. }\end{array}$ \\
\hline
\end{tabular}




\begin{tabular}{|c|c|}
\hline Cita & $\begin{array}{l}\text { Moreno Arteaga, Darío. El sistema politico del clientelismo en Popayán, 1930-1940. } \\
\text { Bogotá: Ministerio de Cultura, } 2002 .\end{array}$ \\
\hline Año & 2002 \\
\hline $\begin{array}{r}\text { Enfoque } \\
\text { teórico }\end{array}$ & Estructural-funcionalista \\
\hline $\begin{array}{r}\text { Categorías } \\
\text { enunciadas }\end{array}$ & Instituciones coloniales; la hacienda. \\
\hline Hipótesis & $\begin{array}{l}\text { "Nuestro trabajo muestra cómo en Popayán y sus entornos termina consolidándose } \\
\text { una cultura política clientelista, situación que paradójicamente no desgastó su clase } \\
\text { política, deterioró eso sí la actividad social del Estado mientras que, por el contrario, } \\
\text { ese sector político se fortalecía". (p. 11) }\end{array}$ \\
\hline $\begin{array}{r}\text { Observaciones } \\
\text { sobre la fuente }\end{array}$ & $\begin{array}{l}\text { Moreno Arteaga hace una revisión historiográfica de las élites políticas de } \\
\text { Popayán. Arguye que en Popayán, al igual que en otras partes del país, se desarrolló } \\
\text { una cultura clientelista que fue producto de un cúmulo de procesos históricos } \\
\text { relacionados con la conquista española y las instituciones traídas a Colombia } \\
\text { desde el continente europeo. Esta cultura clientelista desarrollada por las élites se } \\
\text { comporta tanto como motor de desarrollo como factor de atraso. La tesis principal } \\
\text { es que dicho fenómeno desgastó la actividad social del Estado mientras fortalecía } \\
\text { ampliamente el sector político. La hacienda, producto de una serie de instituciones } \\
\text { coloniales, refuerzan el poder económico, político y social de los patrones sobre sus } \\
\text { clientelas. }\end{array}$ \\
\hline
\end{tabular}

\begin{tabular}{r|l}
\hline Cita & $\begin{array}{l}\text { Pizarro Leongómez, Eduardo. "La atomización partidista en Colombia: el } \\
\text { fenómeno de las micro-empresas electorales". En Degradación o cambio: evolución del } \\
\text { sistema politico colombiano, compilado por Francisco Gutiérrez Sanín, 357. Bogotá: } \\
\text { Editorial Norma, 2002. }\end{array}$ \\
\hline $\begin{array}{r}\text { Enfoque } \\
\text { teórico }\end{array}$ & 2002 \\
\hline $\begin{array}{r}\text { Categorías } \\
\text { enunciadas }\end{array}$ & Institucionalista \\
\hline Hipótesis & $\begin{array}{l}\text { "El objeto de este artículo es, en primer lugar, mostrar la pertinencia de la noción de } \\
\text { microempresa electoral para designar la actual 'atomización personalista' que sufre } \\
\text { el sistema de partidos en Colombia. En segundo término, describir la forma como } \\
\text { los partidos tradicionales se han acomodado de manera pragmática a este sistema } \\
\text { electoral fundado en una generalizada 'guerra de residuos' y, finalmente, analizar } \\
\text { los costos que este modelo desvertebrado de representación genera para el conjunto } \\
\text { del sistema político. A lo largo del artículo intentaremos, igualmente, responder a } \\
\text { las críticas que se han planteado en contra de la noción de micro-empresa electoral, } \\
\text { en particular por parte de Francisco Gutiérrez y Andrés Dávila. Este artículo es útil } \\
\text { para entender el clientelismo de Mercado y el concepto de Micro-empresa". (p. 360) }\end{array}$ \\
\hline $\begin{array}{r}\text { Observaciones } \\
\text { sobre la fuente }\end{array}$ & $\begin{array}{l}\text { Este artículo introduce el término "micro-empresa". Adicionalmente, explica } \\
\text { la transformación del sistema electoral colombiano, de los partidos políticos } \\
\text { tradicionales y de sus redes de clientela. }\end{array}$ \\
\hline
\end{tabular}




\begin{tabular}{r|l}
\hline Cita & $\begin{array}{l}\text { Leal Buitrago, Francisco y Andrés Dávila Ladrón de Guevara. Clientelismo, el sistema } \\
\text { político y su expresión regional. Bogotá: Tercer Mundo Editores, 1991. }\end{array}$ \\
\hline Año & 1991 \\
\hline $\begin{array}{r}\text { Enfoque } \\
\text { teórico }\end{array}$ & Estructural-funcionalista \\
enunciadas & Frente Nacional; crisis; sistema político colombiano; catalizador. \\
\hline Hipótesis & $\begin{array}{l}\text { En este marco la investigación postuló la siguiente tesis: "las relaciones de clientela } \\
\text { permanecieron en su condición de ingrediente importante del sistema político hasta } \\
\text { el Frente Nacional. A partir de allí, por motivos que se explican en este libro, el } \\
\text { clientelismo se proyectó como la relación política principal para articular el sistema } \\
\text { que se organizó con el nuevo régimen. Los recursos estatales proporcionaron los } \\
\text { medios necesarios para mantener esa articulación, y el bipartidismo pasó a ser la } \\
\text { fuente exclusiva de conformación de los gobiernos que administran el Estado. } \\
\text { Los cambios estructurales mencionados -modernización, inserción de la sociedad } \\
\text { colombiana en el capitalismo, urbanización, relaciones económicas monetizadas, } \\
\text { diversificación de las clases sociales, expansión de las Instituciones del Estado- se } \\
\text { convirtieron en el caldo de cultivo para configurar una crisis política que se convirtió } \\
\text { en el problema prioritario de la política gubernamental actual". (p.17-18) }\end{array}$ \\
\hline $\begin{array}{l}\text { Observaciones } \\
\text { sobre la fuente }\end{array}$ & $\begin{array}{l}\text { Este trabajo ha sido reconocido como una de las obras más importantes en el campo } \\
\text { del clientelismo político en Colombia. Articula el macro-análisis con el micro- } \\
\text { análisis, explicando el funcionamiento del sistema político colombiano a partir de } \\
\text { la comprensión de su unidad más pequeña: el municipio y su articulación con el } \\
\text { sistema en su conjunto. Comprende el clientelismo como un catalizador de la crisis } \\
\text { del sistema político colombiano. }\end{array}$ \\
\hline
\end{tabular}

\begin{tabular}{r|l}
\hline Cita & $\begin{array}{l}\text { Duarte, Jesús. Educación pública y clientelismo en Colombia. Medellín: Universidad de } \\
\text { Antioquia, 2003. }\end{array}$ \\
\hline Año & 2003 \\
\hline $\begin{array}{r}\text { Enfoque } \\
\text { teórico }\end{array}$ & Socio-antropológico \\
enunciadas & Distribución de bienes públicos; clientelismo de intermediación organizacional. \\
\hline Hipótesis & $\begin{array}{l}\text { "Se explorará si el clientelismo es un apéndice o la forma predominante de } \\
\text { distribución de servicios públicos en el caso del sector educativo. Se estudiará cuál } \\
\text { es el papel del gobierno central y del departamental, y de los poderes políticos } \\
\text { regionales, en la distribución del servicio. Se examinará si existen redes clientelistas } \\
\text { en el sector, de qué manera se conectan con los partidos o el aparato estatal, las } \\
\text { características de los patronos y los clientes y la clase de bienes que intercambian en } \\
\text { sus transacciones. Para lograr esto, se revisará, por un lado, la estructura política de la } \\
\text { administración de los maestros, y por otro, la manera en que fluyen los recursos para } \\
\text { inversión en el sector educativo y los actores que intervienen en su distribución. En } \\
\text { suma, se observará como opera, en la práctica, la distribución de bienes y servicios } \\
\text { en la educación oficial: empleos, nombramientos, promociones, construcciones y } \\
\text { dotaciones escolares, capacitación, etc.”. (p. 39) }\end{array}$ \\
\hline
\end{tabular}




\begin{tabular}{|c|c|}
\hline $\begin{array}{c}\text { Observaciones } \\
\text { sobre la fuente }\end{array}$ & $\begin{array}{l}\text { Jesús Duarte hace una revisión cuidadosa sobre el estudio del clientelismo en } \\
\text { Colombia. Inicia su discusión mostrando la aparición del término ante la lupa de los } \\
\text { investigadores sociales y la evolución que dichos estudios fueron teniendo. Presenta } \\
\text { además los matices de cada uno de los enfoques que han abordado el problema } \\
\text { para finalmente presentar las premisas base desde donde plantea su investigación. } \\
\text { Particularmente, el autor toma como punto de partida la postura de autores como } \\
\text { Clapham, Eisenstadt y Roginer, quienes asumen el clientelismo como una forma de } \\
\text { distribución de bienes públicos. Su hipótesis consiste en comprobar si realmente el } \\
\text { clientelismo es un mecanismo de distribución de bienes, para ello el autor escoge como } \\
\text { unidad de análisis la distribución de la educación pública en dos municipios del país. } \\
\text { Es importante resaltar que este trabajo se presenta como uno riguroso, que partiendo } \\
\text { de una revisión conceptual clara intenta revisar el mecanismo concreto de distribución } \\
\text { de un bien a partir de las relaciones clientelistas, lo que ante los ojos de Gutiérrez } \\
\text { podría ser considerado como un estudio empírico que ha logrado salirse de los clichés } \\
\text { y las categorías ya establecidas en otros trabajos a propósito del clientelismo. }\end{array}$ \\
\hline
\end{tabular}

\begin{tabular}{r|l}
\hline Cita & $\begin{array}{l}\text { García Sánchez, Miguel. ¿̨ Ciudadanía avergonzada? Democracia local y construcción de } \\
\text { ciudadanía en Bogotá. Bogotá: Universidad de los Andes y Universidad Nacional de } \\
\text { Colombia, 2003. }\end{array}$ \\
\hline $\begin{array}{r}\text { Enfono } \\
\text { teórico }\end{array}$ & 2003 \\
\hline $\begin{array}{r}\text { Categorías } \\
\text { enunciadas }\end{array}$ & Formación de ciudadanía; participación; representación; redes de clientela. \\
\hline Hipótesis & $\begin{array}{l}\text { "A manera de hipótesis, este trabajo propone que ese proceso [formación } \\
\text { de ciudadanía], se desenvuelve en la tensión entre la apertura de espacios de } \\
\text { participación, y el copamiento de ellos por redes políticas locales de tipo clientelista. } \\
\text { Surge así, un fenómeno de construcción de ciudadanía acotado, particularista, } \\
\text { limitado a los ciudadanos que como miembros de las redes de intermediación } \\
\text { política, acceden a los derechos de ciudadanía que ofrecen los nuevos espacios } \\
\text { de representación. La ciudadanía se articula así, en el contexto de la negociación } \\
\text { clientelista, la cual supone que el acceso a los derechos que ofrecen los nuevos } \\
\text { espacios de representación se desenvuelve en medio de una transacción. En } \\
\text { el contexto de esa transacción surge una forma de ciudadanía avergonzada, } \\
\text { que se debate entre la condena a los políticos y la aceptación silenciosa de sus } \\
\text { condiciones, entre la certeza del poder del ciudadano y de los nuevos mecanismos de } \\
\text { representación y el convencimiento de las bondades del clientelismo". (p. 6-7) }\end{array}$ \\
\hline $\begin{array}{l}\text { Observaciones } \\
\text { sobre la fuente }\end{array}$ & $\begin{array}{l}\text { El autor intenta romper con la tensión existente entre clientelismo y democracia, } \\
\text { exponiendo que a través de los espacios de participación ciudadana, abiertos a } \\
\text { partir del proceso de descentralización en Colombia, se han generado procesos } \\
\text { de construcción de la ciudadanía articulados como producto de la negociación } \\
\text { clientelista, a partir de la cual se logra el acceso a bienes y derechos. Esta postura } \\
\text { frente al fenómeno representa una ruptura con los enfoques tradicionales. }\end{array}$ \\
\hline
\end{tabular}




\begin{tabular}{r|l}
\hline Cita & $\begin{array}{l}\text { Losada, Rodrigo. "Reformas regresivas: las reformas electorales propuestas por el } \\
\text { gobierno solo favorecen a los caciques y al clientelismo". Dinero, septiembre, 1996. }\end{array}$ \\
\hline Año & 1996 \\
\hline $\begin{array}{r}\text { Enfoque } \\
\text { teórico }\end{array}$ & Institucionalista \\
enunciadas & Reforma electoral; participación; voto obligatorio. \\
\hline Hipótesis & $\begin{array}{l}\text { "A la luz de estos hallazgos, me pregunto: ¿será que esa enorme masa de } \\
\text { colombianos apáticos, quienes hoy no votan, se volverán individuos interesados por } \\
\text { la política, sencillamente porque les ordenaron votar? ¿Qué gana una democracia } \\
\text { obligando a votar a millones de personas, para quienes la política es algo totalmente } \\
\text { secundario o despreciable? Ahora de lo que se trata es de crear unos incentivos para } \\
\text { animar a algunos a votar, convendría mirar con cuidado cuáles son esos incentivos } \\
\text { y qué puede pasar con ellos. Se ha propuesto que para ser empleado del Estado, } \\
\text { o para contratar con este, se requiera prueba de haber votado. Si esto es así, los } \\
\text { abstencionistas que más se moverían son los que aspiran a un puesto público o } \\
\text { quieren conservarlo. Entonces, los grandes beneficiarios serán, sin duda, los caciques } \\
\text { políticos. ¿Es esto lo que pretende el gobierno con su propuesta?". (p. 182-183) }\end{array}$ \\
\hline $\begin{array}{r}\text { Observaciones } \\
\text { sobre la fuente }\end{array}$ & $\begin{array}{l}\text { Este artículo es importante en la medida en que muestra cuáles fueron los puntos } \\
\text { de discusión a propósito de la reforma electoral de 1996. Lo más importante es que } \\
\text { el autor identifica que las teorías democráticas propuestas por autores como Robert } \\
\text { Dahl y Giovanni Sartori son contradictorias con las prácticas tradicionales políticas } \\
\text { colombianas. Dentro de los temas abordados por el artículo se encuentran: el voto } \\
\text { obligatorio; la unificación del calendario electoral; y la prolongación del periodo } \\
\text { de las autoridades electivas electorales regionales. La pregunta a propósito del voto } \\
\text { obligatorio es: ¿Por qué el voto obligatorio no tuvo un mayor soporte teniendo en } \\
\text { cuenta que esto favorecería mucho más a los grandes caciques políticos? }\end{array}$ \\
\hline
\end{tabular}

\begin{tabular}{r|l}
\hline Cita & $\begin{array}{l}\text { Roll, David Alberto. Rojo difuso y azul pálido. Bogotá: Universidad Nacional de } \\
\text { Colombia, 2002. }\end{array}$ \\
\hline Año & 2002 \\
\hline $\begin{array}{r}\text { Enfoque } \\
\text { teórico }\end{array}$ & Institucionalista \\
$\begin{array}{r}\text { Categorías } \\
\text { enunciadas }\end{array}$ & Crisis política; Frente Nacional; continuismo; inestabilidad; modernidad. \\
\hline Hipótesis & $\begin{array}{l}\text { "El clientelismo, que desprestigió al régimen y debilitó al Estado, se constituyó en } \\
\text { un obstáculo a la modernización política que la transformación económica y social } \\
\text { estaba exigiendo. Paradójicamente, el clientelismo, al hacer posible el continuismo } \\
\text { político, es al mismo tiempo el responsable de la permanencia de las instituciones } \\
\text { formalmente democráticas y de la inestabilidad crónica de padece el país". (p.77) }\end{array}$ \\
\hline
\end{tabular}




\begin{tabular}{l|l}
\hline $\begin{array}{l}\text { Observaciones } \\
\text { sobre la fuente }\end{array}$ & $\begin{array}{l}\text { Según David Roll, al igual que un número significante de analistas políticos, } \\
\text { la capacidad de movilización social de los partidos políticos tradicionales se vio } \\
\text { erosionado desde que se introdujo el pacto frente nacionalista que tendría como } \\
\text { objetivo poner punto final al periodo de la Violencia. La transformación de la } \\
\text { esencia convocante de los partidos no solo implicó una crisis dentro de los mismos, } \\
\text { sino también una crisis a nivel del sistema político en general, este periodo de crisis } \\
\text { y de trasformaciones fue lo que acuñó la aparición del clientelismo burocrático, o } \\
\text { del clientelismo nuevo, llámese como se llame, hablamos del fenómeno tal como } \\
\text { es conocido hoy en día. La neutralización del conflicto a partir del pacto frente } \\
\text { nacionalista condujo a que los partidos entraran en crisis debido a su poca capacidad } \\
\text { convocante. Los partidos encontraron en el clientelismo su mejor aliado para } \\
\text { superar la crisis de legitimidad. Sin embargo, el clientelismo, al mismo tiempo que } \\
\text { cohesionaba, desvirtuaba el sistema político en la medida en que hacía que el Estado } \\
\text { empezara a perder la confianza de sus ciudadanos. }\end{array}$ \\
\hline
\end{tabular}

\begin{tabular}{r|l}
\hline Cita & $\begin{array}{l}\text { Rubio Serrano, Rocío. No hay paraísos sino los perdidos: Historia de una red clientelista } \\
\text { en Bogotá. Bogotá: Universidad Nacional de Colombia, 2003. }\end{array}$ \\
\hline Año & 2003 \\
\hline $\begin{array}{r}\text { Enfoque } \\
\text { teórico }\end{array}$ & Socio-antropológico \\
enunciadas & Forma de representación; red clientelar. \\
\hline Hipótesis & $\begin{array}{l}\text { "En este contexto, es posible lanzar una hipótesis aún más arriesgada, según la } \\
\text { cual ciertas destrezas ciudadanas se aprehenden mediante la participación de los } \\
\text { individuos en redes clientelistas. En últimas, en dichas redes se define buena parte de } \\
\text { la participación política, las formas de dominación y la legitimidad”. (p.32) }\end{array}$ \\
\hline $\begin{array}{r}\text { Observaciones } \\
\text { sobre la fuente }\end{array}$ & $\begin{array}{l}\text { La formación de redes en forma de pactos sociales y la proliferación de } \\
\text { intermediarios que compiten por la captación de clientes han generado que el } \\
\text { clientelismo sea observado como una forma de participación política, donde no } \\
\text { necesariamente es considerado un aspecto opuesto a los procesos de formación de } \\
\text { ciudadanía. Por el contrario, la autora asume el fenómeno como un elemento propio } \\
\text { de la modernidad; se distancia de los juicios moralistas sobre el mismo; y considera } \\
\text { la desigualdad económica como fenómeno que propicia el intercambio que se da } \\
\text { en las relaciones p-c. Esta forma de asumir el fenómeno rompe con las posturas } \\
\text { tradicionales sobre el mismo. }\end{array}$ \\
\hline
\end{tabular}

\begin{tabular}{r|l}
\hline Cita & $\begin{array}{l}\text { Aguirre González, Guillermo. “Clientelismo, caciquismo y caudillismo, expresiones } \\
\text { de una práctica política”. Sociología (2004): 100-106. }\end{array}$ \\
\hline Año & 2004 \\
\hline $\begin{array}{r}\text { Enfoque } \\
\text { teórico }\end{array}$ & Institucionalista \\
\hline $\begin{array}{r}\text { Categorías } \\
\text { enunciadas }\end{array}$ & $\begin{array}{l}\text { Sociedad tradicional; sociedad premoderna; instituciones coloniales; encomienda; } \\
\text { tradición política. }\end{array}$ \\
\hline
\end{tabular}




\begin{tabular}{c|l}
\hline Hipótesis & $\begin{array}{l}\text { "Este artículo muestra cómo la práctica política en Colombia obedece a una } \\
\text { continuidad de la sociedad tradicional pre moderna. La institución colonial de la } \\
\text { encomienda en América, consistió en una relación de dependencia, que se inscribe } \\
\text { en la lógica del clientelismo heredado de la antigüedad romana, y que como tal, pasa } \\
\text { a la vida republicana colombiana. La tradición política que generó esta institución, } \\
\text { es visible en los fenómenos del caciquismo y el caudillismo. Se muestra cómo } \\
\text { el clientelismo es una institución política en Colombia que ha trasegado la vida } \\
\text { republicana hasta hoy. Se concluye mostrando cómo los conceptos de clientelismo, } \\
\text { caudillismo, caciquismo, y gamonalismo, obedecen a una misma lógica del ejercicio } \\
\text { del poder político heredada de la sociedad tradicional”. (p. 100) }\end{array}$ \\
\hline Observaciones & $\begin{array}{l}\text { El autor señala que a pesar de las variaciones en el fenómeno debido al cambio de } \\
\text { sobre la fuente } \\
\text { actores, de las circunstancias y del tipo de bienes y servicios que son intercambiados, } \\
\text { lo que se conoce en pleno siglo xx y xxi como clientelismo es el producto de formas } \\
\text { de relación que se perduran en el presente a pesar de las transformaciones. El estatus } \\
\text { de ciudadano sigue siendo en esencia el cliente de las relaciones clientelistas. }\end{array}$ \\
\hline
\end{tabular}

Observaciones sobre la fuente

Cita Roll, David. "El clientelismo: corrupción a tres bandas". Sindéresis (2000): 114-128.

Año 2000

Enfoque Institucionalista

teórico

Categorías

enunciadas

Hipótesis

Cultura de corrupción; eficacia de la administración pública; detrimento de la representación política (bien no patrimonial); interés particular sobre el colectivo.

"Precisamente la tesis que aquí defendemos es la de que el clientelismo es una especie de corrupción a tres bandas, pues al mismo tiempo que afecta negativamente los bienes y servicios públicos, al feriarlos, perjudica un bien no patrimonial del Estado -la representación-, y por añadidura contribuye a generar una cultura de la corrupción, la cual se expresa en actos diferentes pero inspirados en el mismo anti principio de la preeminencia del interés particular sobre el colectivo". (p.115)

El autor parte del hecho de que el clientelismo es un fenómeno presente en todos los regímenes políticos en general. El clientelismo aparece como un problema que debe buscar ser superado cuando el fenómeno se convierte casi en el modus operandi del sistema. Para el autor, el clientelismo es una forma de corrupción política en tres sentidos: afecta los bienes y servicios públicos; perjudica la representación; y contribuye a generar una cultura de la corrupción. Este modelo de operación trae fuertes consecuencias sobre la legitimidad y eficacia del régimen y de la administración pública. Sin embargo, las soluciones propuestas a este problema deben trascender cualquier acción únicamente basada en ingeniería institucional, ya que se trata de un aspecto casi del comportamiento político tanto de los políticos como de los ciudadanos, estos vistos como redes de clientela.

\begin{tabular}{r|l}
\hline Cita & $\begin{array}{l}\text { Roll, David. Inestabilidad y continuismo en la dinámica del cambio político en Colombia: } \\
\text { perspectiva de la reforma politica en Colombia desde 1930 basta 1991. Santafé de } \\
\text { Bogotá: IcFes, 1999. }\end{array}$ \\
\hline Año & 1999 \\
\hline $\begin{array}{r}\text { Enfoque } \\
\text { teórico }\end{array}$ & Institucionalista \\
\hline
\end{tabular}




\begin{tabular}{|c|c|}
\hline $\begin{array}{r}\text { Categorías } \\
\text { enunciadas }\end{array}$ & $\begin{array}{l}\text { Modernidad, tradición, Bipartidismo, clientelismo, crisis de legitimidad, democracia, } \\
\text { capitalismo, continuismo político }\end{array}$ \\
\hline Hipótesis & $\begin{array}{l}\text { "La hipótesis básica de esta investigación es la de que la crisis política colombiana } \\
\text { tiene un carácter estructural, que se expresa a través de una crisis de legitimidad y } \\
\text { que es producto de una dinámica de cambio caracterizada por el continuismo y la } \\
\text { inestabilidad. Esto se ha pretendido lograr a continuación haciendo un seguimiento } \\
\text { de cómo ha operado el continuismo en la dinámica del cambio político en Colombia } \\
\text { y cuáles han sido sus consecuencias. Por ello, el análisis de las mencionadas } \\
\text { reformas políticas escapa al presente estudio. De hecho sus efectos en lo referente } \\
\text { al continuismo y a la inestabilidad aún son difíciles de determinar. Baste decir que } \\
\text { algunos hechos posteriores a estas reformas parecen demostrar una de las hipótesis } \\
\text { del continuismo político en Colombia: que la modernización de las instituciones } \\
\text { políticas no implica necesariamente su democratización. No obstante cualquier } \\
\text { avance en este sentido debe considerarse como positivo, pues superar el continuismo } \\
\text { político, que se ha arraigado tan férreamente al sistema político colombiano a través } \\
\text { de los sucesivos procesos de cambio, hace suponer que se requiere de un proceso de } \\
\text { transformación lento, dificultoso y con inevitables rectificaciones". (p. 19-20) }\end{array}$ \\
\hline $\begin{array}{l}\text { Observaci } \\
\text { sobre la fu }\end{array}$ & $\begin{array}{l}\text { David Roll atribuye la crisis de los años setenta del sistema político colombiano a tres } \\
\text { aspectos mutuamente relacionados de la historia del país, que son, a saber: la crisis de } \\
\text { legitimidad; la crisis del bipartidismo; y el clientelismo. El autor no entiende la crisis } \\
\text { como un asunto coyuntural, sino, más bien, como un tremendo choque estructural } \\
\text { del sistema que se empieza a consolidar en los setenta, producto de la llegada de la } \\
\text { modernidad, del capitalismo y de otras tantas instituciones democráticas, contra la } \\
\text { oposición de ciertas élites políticas y económicas a dichos procesos. El continuismo } \\
\text { es una categoría que usa Roll para referirse a "la tendencia del régimen a incorporar } \\
\text { elementos tradicionales en las instituciones modernas". El clientelismo, ante este } \\
\text { panorama, fue el mecanismo predilecto utilizado por los partidos para mantener su } \\
\text { poder en medio de la crisis de legitimidad que se vivía en el momento. }\end{array}$ \\
\hline
\end{tabular}

\begin{tabular}{|c|c|}
\hline Cita & $\begin{array}{l}\text { Múnera Rojas, Betty Paola. "Clientelismo mafioso: estudio de caso de una red } \\
\text { clientelista para elecciones de alcalde". Tesis de pregrado, Universidad de los Andes, } \\
\text { Bogotá, } 2006 .\end{array}$ \\
\hline Año & 2006 \\
\hline $\begin{array}{r}\text { Enfoque } \\
\text { teórico }\end{array}$ & Institucionalista \\
\hline $\begin{array}{l}\text { Categorías } \\
\text { enunciadas }\end{array}$ & Clientelismo mafioso; participación; clientelismo armado. \\
\hline Hipótesis & $\begin{array}{l}\text { "A manera de hipótesis se pretende argumentar que a nivel local el proceso electoral } \\
\text { para Alcaldía Distrital del Corralito se ha caracterizado por la consolidación } \\
\text { de reglas informales y el surgimiento de una nueva modalidad de clientelismo: } \\
\text { el clientelismo mafioso. Esta modalidad se ha presentado en distintas ciudades } \\
\text { intermedias del país, en el caso del Corralito se presentó con gran alcance en el } \\
\text { proceso electoral para Alcaldía del 2003". (p. 4) }\end{array}$ \\
\hline
\end{tabular}




\begin{tabular}{l|l}
\hline $\begin{array}{l}\text { Observaciones } \\
\text { sobre la fuente }\end{array}$ & $\begin{array}{l}\text { El clientelismo es considerado como un contrato informal que se consolida en } \\
\text { Corralito a partir del evento de las elecciones de alcalde de 2003. Emerge una nueva } \\
\text { tipología de clientelismo llamado clientelismo mafioso. Ante las afirmaciones que ya } \\
\text { han formulado otros autores al referirse al clientelismo como un fenómeno moderno } \\
\text { mezclado con dinámicas de mercado, la autora plantea la posibilidad de que } \\
\text { fenómenos como el clientelismo estén relacionados con la inserción del narcotráfico } \\
\text { en la política, lo cual se manifiesta con llegada de dineros ilícitos a campañas } \\
\text { electorales, la crisis de los partidos políticos, los bajos índices de participación } \\
\text { ciudadana y la evolución del conflicto armado que desangra al país. Con la } \\
\text { emergencia de nuevos actores, se da origen al clientelismo mafioso. El clientelismo } \\
\text { mafioso pone en riesgo la formación de espacios propicios para la participación } \\
\text { ciudadana e impide la formación de espacios cívicos. }\end{array}$ \\
\hline
\end{tabular}

\begin{tabular}{r|l}
\hline Cita & $\begin{array}{l}\text { Mendoza M., Adaulfo Enrique. "Estado, clientelismo y sociedad: una mirada desde } \\
\text { la función política de la Educación”. Cuestiones iv (2007): 97-108. }\end{array}$ \\
\hline $\begin{array}{r}\text { Año } \\
\text { teórico }\end{array}$ & 2007 \\
\hline $\begin{array}{r}\text { Categorías } \\
\text { enunciadas }\end{array}$ & Institucionalista \\
\hline Hipótesis & $\begin{array}{l}\text { "El clientelismo como una práctica social generadora de contradicciones en la } \\
\text { configuración del Estado-Nación, sobre todo si se tiene en cuenta que la educación } \\
\text { en este proceso ha sido asumida como: 1) Factor fundamental para hacer real la } \\
\text { igualdad política, en tanto su universalización se ha convertido en un poderoso } \\
\text { instrumento para superar la desigualdad de las personas ante el Estado y posibilitar } \\
\text { la integración de todas las personas a la comunidad de ciudadanos; 2) Instrumento } \\
\text { de control y cohesión política: desde el punto de vista de la integración política, el } \\
\text { Estado liberal concibió la educación como elemento sustancial para el logro de una } \\
\text { nueva lealtad y procuró que las clases medias y superiores, base del nuevo régimen } \\
\text { representativo, tuvieran fácil acceso al sistema educativo". (p. 97-98) }\end{array}$ \\
\hline $\begin{array}{l}\text { Observaciones } \\
\text { sobre la fuente }\end{array}$ & $\begin{array}{l}\text { La educación es vista como una herramienta para la difusión de los mecanismos } \\
\text { clientelistas, aspecto que compite con la legitimidad del Estado. }\end{array}$ \\
\hline
\end{tabular}

\begin{tabular}{r|l}
\hline Cita & $\begin{array}{l}\text { Santos Villagrán, Rafael José. "Bogotá: The Collapse of a Political Machine”. Cuadernillo } \\
\text { no publicado, Universidad de los Andes, Facultad de Economía, Bogotá,2007. }\end{array}$ \\
\hline Año & 2007 \\
\hline $\begin{array}{r}\text { Enfoque } \\
\text { teórico }\end{array}$ & Institucionalista \\
enunciadas & Voto de opinión; clientelismo; colapso de la maquinaria política; bienes públicos. \\
\hline Hipótesis & $\begin{array}{l}\text { "These elements, jointly taken, lead to the formulation of a series of hypotheses. The } \\
\text { election of the first independent mayor of Bogotá and the increase in the provision } \\
\text { of public goods and services are explained by the collapse of a political machine and } \\
\text { by the transit from an exchange vote of opinion. After 1991 reforms, vote buying } \\
\text { lost effectiveness as a mechanism to reach the Mayor's Office. With a machine that } \\
\text { did not function properly, traditional parties lost control over their clientele and } \\
\text { limited the use of State resources for discretionary transfers". (p. 13) }\end{array}$ \\
\hline
\end{tabular}




\begin{tabular}{l|l}
\hline Observaciones & $\begin{array}{l}\text { Este autor dirige su investigación hacia la compra y venta de votos durante las } \\
\text { sobre la fuente } \\
\text { elecciones de alcalde en Bogotá desde } 1988 \text { hasta 2003. Concluye que a partir de la } \\
\text { constitución de } 1991 \text { se genera el "colapso de la maquinaria política". Este aspecto } \\
\text { se pone en evidencia con la victoria electoral de candidatos independientes de los } \\
\text { partidos tradicionales, evidenciando una caída del voto clientelista y el surgimiento } \\
\text { de un voto de opinión. El autor parte del presupuesto de que el clientelismo es un } \\
\text { mecanismo de distribución de bienes y recursos que dependen discrecionalmente del } \\
\text { patrón. Esto genera una provisión deficiente de bienes públicos, ya que la necesidad } \\
\text { de estos no depende de la opinión de los políticos, sino de niveles óptimos de acceso. } \\
\text { Para el autor, las reformas de 1991 condujeron a una ruptura de las grandes pirámides } \\
\text { clientelistas, lo que a su vez condujo a una mejor dotación de bienes públicos debido } \\
\text { a una menor cantidad de recursos distribuidos a discreción de los políticos. Una } \\
\text { crítica que se le podría formular a esta investigación es que el autor da por hecho la } \\
\text { dotación de bienes públicos en niveles óptimos a partir de la elección de candidatos } \\
\text { independientes, cuando otros estudios han demostrado precisamente lo contrario: el } \\
\text { clientelismo en Bogotá buscó nuevas formas de operación. }\end{array}$ \\
\hline
\end{tabular}

\begin{tabular}{|c|c|}
\hline Cita & $\begin{array}{l}\text { Fonseca Galvis, Ángela María. "El elefante en la Caja Agraria”. Tesis de maestría, } \\
\text { Universidad de los Andes, Bogotá, } 2008 .\end{array}$ \\
\hline Año & 2008 \\
\hline $\begin{array}{r}\text { Enfoque } \\
\text { teórico }\end{array}$ & Institucionalista \\
\hline $\begin{array}{r}\text { Categorías } \\
\text { enunciadas }\end{array}$ & Captura institucional; redistribución de bienes; elecciones. \\
\hline Hipótesis & $\begin{array}{l}\text { "La pregunta que se plantea en este trabajo es: ¿Utilizó Ernesto Samper la cartera de } \\
\text { la Caja Agraria para ganar el apoyo de los representantes a la Cámara que decidieron } \\
\text { precluir el proceso en su contra? En particular, nos interesa saber si los municipios } \\
\text { cuya población apoyaba a los congresistas samperistas recibieron un mejor } \\
\text { tratamiento por parte de la Caja Agraria, ya sea en un mayor volumen de créditos o } \\
\text { con créditos que fueron calificados más favorablemente por parte de la entidad; y a } \\
\text { su vez, si esto influyó sobre la forma como votaron los representantes a la Cámara en } \\
\text { la que decidieron precluir el proceso contra Samper. La hipótesis que proponemos } \\
\text { sostiene que la Caja Agraria sí fue manipulada por el Presidente de la República } \\
\text { para favorecer sus intereses y mantenerse en el poder, dándoles a determinados } \\
\text { congresistas las herramientas para ejercer su influencia sobre las oficinas que les } \\
\text { interesaran. Esta Captura de la Caja Agraria por parte del Ejecutivo implicó la } \\
\text { aprobación de créditos en los municipios fieles a ciertos congresistas, lo que influyó } \\
\text { para que votaran a favor de cerrar el proceso contra Samper". (p. 2-3) }\end{array}$ \\
\hline $\begin{array}{r}\text { Observaciones } \\
\text { sobre la fuente }\end{array}$ & $\begin{array}{l}\text { El clientelismo es visto como una política de redistribución utilizada por los } \\
\text { políticos para aumentar las posibilidades de su elección y de mantenerse en el juego } \\
\text { político. Según este enfoque, los políticos hacen sus promesas dependiendo del tipo } \\
\text { de clientela a la que se dirigen, ya sea esta una clientela conformada por políticos que } \\
\text { forman cuerpos colegiados, simpatizantes del partido o potenciales electores dentro } \\
\text { de los que se encuentra la ciudadanía. Es interesante recalcar que el clientelismo, en } \\
\text { este enfoque, está directamente relacionado con una coyuntura electoral, ya que la } \\
\text { clientela se configura alrededor de unas necesidades económicas que son prometidas } \\
\text { y efectivamente cumplidas, aspecto que asegura que la clientela continúe dando } \\
\text { apoyo político al "patrón", pero además, propicia la captura institucional de ciertas } \\
\text { instituciones públicas, especialmente de las bancarias. Este trabajo es una tesis de } \\
\text { maestría, continuación de la tesis de pregrado "Clientelismo en la Caja Agraria: la } \\
\text { caja menor de los políticos". Universidad de los Andes, Bogotá, 2007. }\end{array}$ \\
\hline
\end{tabular}




\begin{tabular}{|c|c|}
\hline Cita & $\begin{array}{l}\text { Gallego Durán, Jorge Andrés y Rafael Raciborsky. "Clientelism, Income Inequality, } \\
\text { and Social Preferences: An Evolutionary Approach to Poverty Traps. Informe no } \\
\text { publicado, Pontificia Universidad Javeriana, Facultad de Ciencias Económicas y } \\
\text { Administrativas, Departamento de Economía, Bogotá, 2008. }\end{array}$ \\
\hline Año & 2008 \\
\hline $\begin{array}{r}\text { Enfoque } \\
\text { teórico }\end{array}$ & Teoría de Juegos \\
\hline $\begin{array}{r}\text { Categorías } \\
\text { enunciadas }\end{array}$ & Clientelismo; pobreza; desigualdad en el ingreso; reciprocidad. \\
\hline Hipótesis & $\begin{array}{l}\text { "[...] The important issue is that reciprocity links the unequal relation } \\
\text { between the patron and the client. When the politician gives protection } \\
\text { or material benefits to the citizens, the latter can deviate from cooperation } \\
\text { and abstain or give his political support to other candidate. Why does } \\
\text { he behave kindly with the clientelistic candidate? Reciprocity is an } \\
\text { explanation. Self-interest could be another one. Afraid of losing future } \\
\text { benefits or of being punished, the client prefers to reciprocate the patron } \\
\text { with his support. But both explanations, reciprocity and self-interest, } \\
\text { are compatible with one another. In fact, Scott adds that 'although the } \\
\text { balance of benefits may heavily favor the patron, some reciprocity is } \\
\text { involved and it is this quality which distinguishes patron-client dyads } \\
\text { from relationships of pure coercion of formal authority that also may link } \\
\text { individuals of different status'. Then, political clientelism may emerge even } \\
\text { in situations in which the candidate does not hold coercive mechanisms } \\
\text { or credible threats of punishment against the citizens, as a consequence of } \\
\text { reciprocity". (p. 5) }\end{array}$ \\
\hline $\begin{array}{l}\text { Observaciones } \\
\text { sobre la fuente }\end{array}$ & $\begin{array}{l}\text { Esta investigación aborda el fenómeno desde el campo de la economía. } \\
\text { Para lo anterior basa sus explicaciones en modelos económicos sustentados } \\
\text { en la teoría de los juegos. Según los autores, la razón por la cual un } \\
\text { individuo acepta voluntariamente involucrarse en una relación que implica } \\
\text { desigualdad puede ser explicada a través de la reciprocidad y del interés } \\
\text { personal. Estos dos elementos son los que distancian al clientelismo de } \\
\text { otras relaciones punitivas basada en la violencia. Algo importante que } \\
\text { anotan los autores es que la reciprocidad es el elemento que distancia al } \\
\text { clientelismo de fenómenos de intercambio coercitivo, sugiriendo que la } \\
\text { relación clientelista, aunque desigual, siempre es voluntaria. }\end{array}$ \\
\hline
\end{tabular}

\begin{tabular}{r|l}
\hline Cita & $\begin{array}{l}\text { Torres Preciado, Javier Fernando. “Vicio y virtud: el sistema político colombiano en } \\
\text { el periodo 1848-1885”. Tesis de maestría, Universidad de los Andes, Bogotá, 2008. }\end{array}$ \\
\hline Año & 2008 \\
\hline $\begin{array}{r}\text { Enfoque } \\
\text { teórico }\end{array}$ & Estructural-funcionalista \\
\hline $\begin{array}{r}\text { Categorías } \\
\text { enunciadas }\end{array}$ & $\begin{array}{l}\text { Siglo xix y xx; choque modernidad y tradición; vicio y virtud; democracia formal; } \\
\text { democracia substancial. }\end{array}$ \\
\hline
\end{tabular}




\begin{tabular}{c|l}
\hline Hipótesis & $\begin{array}{l}\text { "Junto a lo anterior se pretende, a manera de hipótesis, confirmar que con los } \\
\text { elementos negativos o viciosos', confirmados por la literatura sobre el sistema } \\
\text { político en el siglo xx, convivieron una serie de características positivas o 'virtuosas' } \\
\text { que le han proporcionado cierta estabilidad y equilibrio al funcionamiento de la } \\
\text { política en Colombia desde su nacimiento como república". (p. 5) }\end{array}$ \\
\hline $\begin{array}{l}\text { Observaciones } \\
\text { sobre la fuente }\end{array}$ & $\begin{array}{l}\text { Este trabajo es una revisión historiográfica sobre el sistema político del siglo xix } \\
\text { en lo que comprende el periodo de 1848-1885. El trabajo tiene como objetivo } \\
\text { ratificar los planteamientos de Leal y Dávila en lo concerniente al sistema político } \\
\text { colombiano de finales del siglo xx y comienzos del xxi. El autor arguye que durante } \\
\text { el siglo xix hubo intentos por adoptar estructuras modernas con principios liberales, } \\
\text { sin embargo los vacíos de la formalidad del régimen fueron pronto subsanados por } \\
\text { dinámicas informales que terminaron de configurar el sistema político colombiano. } \\
\text { Como producto de ese sincretismo entre lo tradicional y lo moderno, el sistema } \\
\text { político colombiano del siglo xx presenta una serie de características que se } \\
\text { remontan al siglo xix: una serie de choques entre lo tradicional y lo moderno, entre } \\
\text { lo formal y lo informal, ente lo vicioso y lo virtuoso, que dan al régimen estabilidad y } \\
\text { lo catalogan como uno de los más democráticos del continente y, a la vez, como uno } \\
\text { de los más excluyentes, oligárquicos y antidemocráticos. }\end{array}$ \\
\hline
\end{tabular}

\begin{tabular}{r|l}
\hline Cita & $\begin{array}{l}\text { Ramírez Montenegro, Verónica. Análisis de la participación en ejercicios de control } \\
\text { ciudadano sobre la gestión pública estatal. Monografía de grado, Universidad del } \\
\text { Rosario, Bogotá, 2009. }\end{array}$ \\
\hline $\begin{array}{r}\text { Enfoque } \\
\text { teórico }\end{array}$ & 2009 \\
\hline $\begin{array}{r}\text { Categorías } \\
\text { enunciadas }\end{array}$ & $\begin{array}{l}\text { Control político; orientaciones cognitivas precarias; rezagos de dominación } \\
\text { patrimonial en la ciudad; desigualdad en la distribución del ingreso; las lógicas } \\
\text { particularistas que provoca el liberalismo a ultranza; limitada promoción de los } \\
\text { canales de control ciudadano por parte de los gobiernos locales; participación } \\
\text { política. }\end{array}$ \\
\hline Hipótesis & $\begin{array}{l}\text { "La hipótesis preliminar consistía en otorgar a las orientaciones afectivas y } \\
\text { evaluativas que poseen los ciudadanos respecto a su sistema político local, la } \\
\text { responsabilidad de un supuesto bajo nivel de control ciudadano, a medida que } \\
\text { avanzaba la investigación la hipótesis se fue ampliando al considerar además de estos } \\
\text { factores, otros elementos. Entre estos otros factores se encuentran orientaciones } \\
\text { cognitivas precarias, rezagos de dominación patrimonial en la ciudad, desigualdad } \\
\text { en la distribución del ingreso, las lógicas particularistas que provoca el liberalismo } \\
\text { a ultranza, y limitada promoción de los canales de control ciudadano por parte de } \\
\text { los gobiernos locales. Además de ello se encuentran enunciados los factores que } \\
\text { caracterizan el tipo de participación en control existente en la ciudad". (p.5) }\end{array}$ \\
\hline $\begin{array}{l}\text { Observaciones } \\
\text { sobre la fuente }\end{array}$ & $\begin{array}{l}\text { El control político es asumido como una forma de participación política. Los } \\
\text { bajos niveles de control ciudadano en la ciudad de Cali están relacionados con } \\
\text { orientaciones afectivas y evaluativas que tienen los ciudadanos con respecto al } \\
\text { sistema político local, sin embargo existen otros factores tales como orientaciones } \\
\text { cognitivas precarias, los rezagos de dominación patrimonial en la ciudad, desigualdad } \\
\text { en la distribución del ingreso, las lógicas particularistas que provoca el liberalismo a } \\
\text { ultranza y limitada promoción de los canales de control ciudadano por parte de los } \\
\text { gobiernos locales, que afectan los niveles de participación político en la ciudad. }\end{array}$ \\
\hline
\end{tabular}




\begin{tabular}{|c|c|}
\hline Cita & $\begin{array}{l}\text { Wills Obregón, María Emma y Rivera Bonza, María Milagros. “Poder, familia y } \\
\text { clientelismos en Montería, Córdoba (1950-2008): Visibilización y ascenso de las } \\
\text { mujeres en contextos totalitarios”. En A la sombra de la guerra: ilegalidad y nuevos } \\
\text { órdenes regionales en Colombia, } 97-164 \text {. Bogotá: Universidad de los Andes, Facultad } \\
\text { de Ciencias Sociales, Centro de Estudios Socioculturales, } 2009 .\end{array}$ \\
\hline Año & 2009 \\
\hline $\begin{array}{r}\text { Enfoque } \\
\text { teórico }\end{array}$ & Marxista \\
\hline $\begin{array}{r}\text { Categorías } \\
\text { enunciadas }\end{array}$ & Género; violencia; paramilitarismo. \\
\hline Hipótesis & 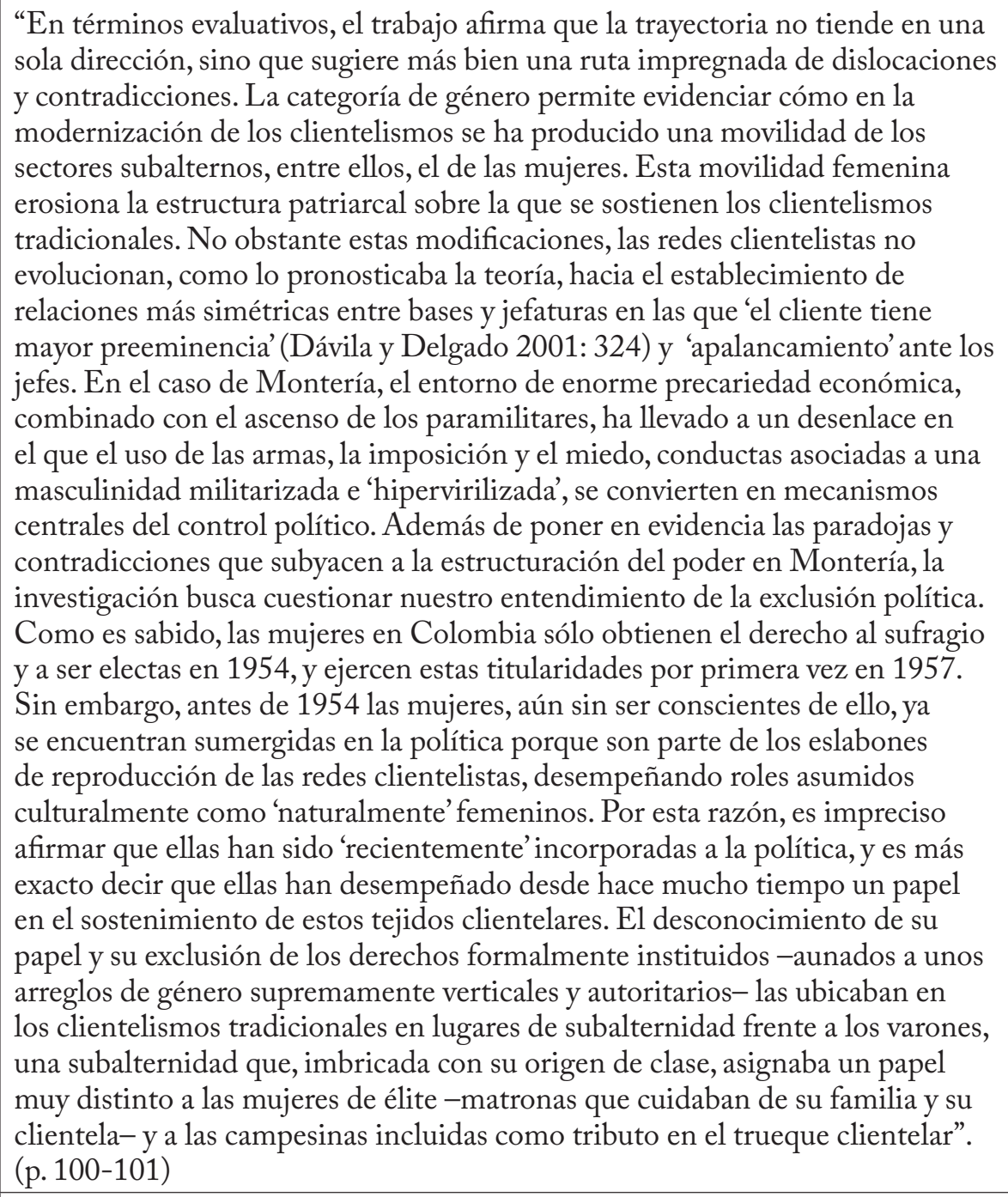 \\
\hline $\begin{array}{c}\text { Observaciones } \\
\text { sobre la fuente }\end{array}$ & $\begin{array}{l}\text { El clientelismo se ha transformado en la medida en que diferentes grupos sociales } \\
\text { que habían estado excluidos de los ejercicios de poder acceden a los puestos más } \\
\text { altos de la estructura piramidal de la clientela; sin embargo, dichas transformaciones } \\
\text { no comprenden, como afirma Dávila, una posición con mayores oportunidades } \\
\text { para los clientes, solo generan nuevas formas de control político sustentados en la } \\
\text { violencia y en la llegada de grupos paramilitares. El trabajo es planteado y formulado } \\
\text { desde un enfoque de estudios de género. }\end{array}$ \\
\hline
\end{tabular}




\begin{tabular}{r|l}
\hline Cita & $\begin{array}{l}\text { Cepeda Van Houten, Álvaro. Neo pentecostalismo y política. El caso colombiano. Cali: } \\
\text { Universidad de San Buenaventura, 2010. }\end{array}$ \\
\hline Año & 2010 \\
\hline $\begin{array}{r}\text { Enfoque } \\
\text { teórico }\end{array}$ & Institucionalista \\
\hline $\begin{array}{r}\text { Categorías } \\
\text { enunciadas }\end{array}$ & Clientelismo religioso; Constitución de 1991. \\
\hline Hipótesis & $\begin{array}{l}\text { "Se explicará a continuación cómo el clientelismo ha sido la estrategia más } \\
\text { eficaz para lograr las cohesiones partidistas, proceso en el cual el componente } \\
\text { religioso ha jugado un papel fundamental convirtiéndose a su vez en un fenómeno } \\
\text { político-religioso que en la actualidad ocupa un lugar central por vía de los pastores } \\
\text { pentecostales que han decidido entrar al campo de la política gracias al pluralismo } \\
\text { religioso propuesto en la Constitución de 1991. La participación política de los } \\
\text { pastores, a pesar de ser una expresión del pluralismo religioso, paradójicamente está } \\
\text { develando una confesionalidad del Estado que se creía enfocado más a un proceso de } \\
\text { laicización". (p. 40) }\end{array}$ \\
\hline $\begin{array}{l}\text { Observaciones } \\
\text { sobre la fuente }\end{array}$ & $\begin{array}{l}\text { Algunos partidos políticos hicieron uso de la religión católica como herramienta de } \\
\text { cooptación de votos, a partir de la Constitución de 1991 y la apertura a la libertad } \\
\text { de culto. El análisis que presenta esta investigación evidencia que los nuevos } \\
\text { mecanismos instituidos por la Constitución de 1991 no escaparon del viejo sistema } \\
\text { clientelista; a pesar de la aparición de nuevos actores en la escena política, se mostró } \\
\text { la reproducción de una dificultad por ejercer dinámicas democráticas. }\end{array}$ \\
\hline
\end{tabular}

\begin{tabular}{r|l}
\hline Cita & $\begin{array}{l}\text { García Villegas, Mauricio y Javier Eduardo Revelo Rebolledo. Estado alterado. } \\
\text { Clientelismo, mafias y debilidad institucional en Colombia. Bogotá: Centro de estudios } \\
\text { de Derecho, Justicia y Sociedad, 2010. }\end{array}$ \\
\hline $\begin{array}{r}\text { Eño } \\
\text { teórico }\end{array}$ & Institucionalista \\
\hline $\begin{array}{r}\text { Categorías } \\
\text { enunciadas }\end{array}$ & $\begin{array}{l}\text { Corrupción; ilegalidad; debilidad institucional; clientelismo mafioso; abuso de } \\
\text { poder; captura de las instituciones. }\end{array}$ \\
\hline Hipótesis & $\begin{aligned} \text { "La debilidad tradicional de las instituciones locales en Colombia, afectadas por } \\
\text { el clientelismo y la incapacidad para imponerse frente a los poderes sociales y } \\
\text { económicos locales, no sólo se ha mantenido durante estos años, sino que se ha } \\
\text { reforzado y, en algunos casos, ha adquirido visos de clara ilegalidad debido a la } \\
\text { transformación del clientelismo tradicional en clientelismo armado, y al paso de las } \\
\text { negociaciones clientelistas a la captura institucional". (p. 18) }\end{aligned}$ \\
\hline $\begin{array}{r}\text { Observaciones } \\
\text { sobre la fuente }\end{array}$ & $\begin{array}{l}\text { Para el autor, la debilidad institucional y el clientelismo son dos aspectos que } \\
\text { favorecen la captura de las instituciones por parte de organizaciones mafiosas ilegales. } \\
\text { Sin embargo, la debilidad institucional no siempre desemboca en un clientelismo } \\
\text { mafioso. Este último es una característica particular del caso colombiano y es } \\
\text { producto del conflicto armado y de las estructuras del poder local. Este autor } \\
\text { comprende el clientelismo como una institución informal que llega a ser más eficiente } \\
\text { que otras instituciones formales como la ley. Por ello, el fenómeno es visto como algo } \\
\text { contrario a la formación de ciudadanía, al Estado de derecho y a la modernidad, a la } \\
\text { vez que crea situaciones propicias para la corrupción,la ilegalidad y el abuso del poder. }\end{array}$ \\
\hline
\end{tabular}




\begin{tabular}{r|l}
\hline Cita & $\begin{array}{l}\text { Hernández Humberto, Luis. “Colombia: Mafia y sistema político". En } \dot{E} \text { Estado y } \\
\text { cultura mafosa en Colombia?, editado por Óscar Mejía Quintana, 127-147. Bogotá: } \\
\text { Universidad Nacional de Colombia, Facultad de Derecho, Ciencias Políticas y } \\
\text { Sociales, Instituto Unidad de Investigaciones Jurídico-Sociales Gerardo Molina, 2010. }\end{array}$ \\
\hline $\begin{array}{r}\text { Año } \\
\text { teórico }\end{array}$ & 2010 \\
\hline $\begin{array}{r}\text { Categorías } \\
\text { enunciadas }\end{array}$ & Estructural-funcionalista \\
\hline Hipótesis & $\begin{array}{l}\text { Cultura mafiosa; corrupción; clientelismo; ilegalidad. } \\
\text { ha sido y es campo abonado para el despliegue de actividades criminales ilícitas, } \\
\text { dentro de las que se comprenden las mafiosas y su cultura, sin ser esta la única ni la } \\
\text { hegemónica aunque se haya cruzado con las demás, complicando el espectro de la } \\
\text { ilegitimidad y legalidad del sistema político mismo". (p. 128) }\end{array}$ \\
\hline $\begin{array}{r}\text { Observaciones } \\
\text { sobre la fuente }\end{array}$ & $\begin{array}{l}\text { La cultura política colombiana, al igual que el sistema político, es vista como un } \\
\text { constructo que se nutre de procesos políticos, históricos, sociales, económicos y } \\
\text { culturales. La cultura mafiosa y la propensión a la ilegalidad están dadas por dos } \\
\text { razones estructurantes: la primera es la dificultad para consolidar un Estado-Nación } \\
\text { moderno y la segunda es la llegada de una modernidad a medias. En medio de estos } \\
\text { elementos, el clientelismo es visto como lo que llena todos los vacíos que el Estado } \\
\text { no puede satisfacer, pero que al mismo tiempo imposibilita la formación de una } \\
\text { ciudadanía activa que ejerza plenamente la dinámica democrática, haciendo del } \\
\text { sistema político colombiano un sistema proclive a las mafias, a la ilegalidad y a la } \\
\text { corrupción. }\end{array}$ \\
\hline
\end{tabular}

\begin{tabular}{|c|c|}
\hline Cita & $\begin{array}{l}\text { León Monsalvo, Alfredo Antonio. Penumbras y demonios en la politica colombiana: un } \\
\text { análisis sobre el clientelismo. Bogotá: Ediciones Desde abajo, } 2011 .\end{array}$ \\
\hline Año & 2011 \\
\hline $\begin{array}{r}\text { Enfoque } \\
\text { teórico }\end{array}$ & Institucionalista \\
\hline $\begin{array}{r}\text { Categorías } \\
\text { enunciadas }\end{array}$ & $\begin{array}{l}\text { Clientelismo; instituciones formales e informales; corrupción; capitalismo; } \\
\text { democracia; bienes públicos. }\end{array}$ \\
\hline Hipótesis & $\begin{array}{l}\text { "El texto hace visible el fenómeno de clientelismo, observando el comportamiento } \\
\text { de los actores en la política colombiana, sobre todo en el legislativo, y advierte } \\
\text { que la democracia colombiana es defectuosa y que, aunque tenga instituciones } \\
\text { formales democráticas, debe luchar con instituciones informales que impiden } \\
\text { el funcionamiento correcto de las instituciones formales, sobre todo por el } \\
\text { comportamiento de los actores". (p. 11) }\end{array}$ \\
\hline $\begin{array}{c}\text { Observaciones } \\
\text { sobre la fuente }\end{array}$ & $\begin{array}{l}\text { El clientelismo ha sido usado como una categoría genérica útil para describir todo } \\
\text { tipo de vicios del sistema político colombiano. En un primer ejercicio de comprensión } \\
\text { del fenómeno, este autor propone } 17 \text { tipologías de clientelismo, clasificados por } \\
\text { el tipo de patrón o por el bien que se intercambia. Se dan lugares importantes al } \\
\text { clientelismo, a temas electorales y a prácticas que se reproducen a lo largo del tiempo } \\
\text { en diferentes generaciones. El clientelismo es asumido como una institución informal } \\
\text { que se entrelaza con una institución formal: la democracia. La relación entre estas dos } \\
\text { instituciones, una formal y otra informal, produce una confrontación de sistemas que } \\
\text { en ocasiones implica el no cumplimiento de ciertas normas. }\end{array}$ \\
\hline
\end{tabular}




\begin{tabular}{|c|c|}
\hline Cita & $\begin{array}{l}\text { Guillén Martínez, Fernando. El poder político en Colombia. Bogotá: Punta de lanza, } \\
1979 .\end{array}$ \\
\hline Año & 1979 \\
\hline $\begin{array}{r}\text { Enfoque } \\
\text { teórico }\end{array}$ & Estructuralista \\
\hline $\begin{array}{l}\text { Categorías } \\
\text { enunciadas }\end{array}$ & Formas de asociación; la hacienda; la encomienda; el sindicalismo. \\
\hline Hipótesis & $\begin{array}{l}\text { "Para comprender las formas de asociación políticas y sus valores específicos dentro } \\
\text { de la sociedad, es menester rastrear la formación de las estructuras de poder en } \\
\text { una perspectiva histórica, porque las organizaciones iniciales han condicionado } \\
\text { y condicionarán en gran medida todas las formas ulteriores de agrupamiento } \\
\text { colectivo". (p. 12) }\end{array}$ \\
\hline $\begin{array}{l}\text { Observaciones } \\
\text { sobre la fuente }\end{array}$ & 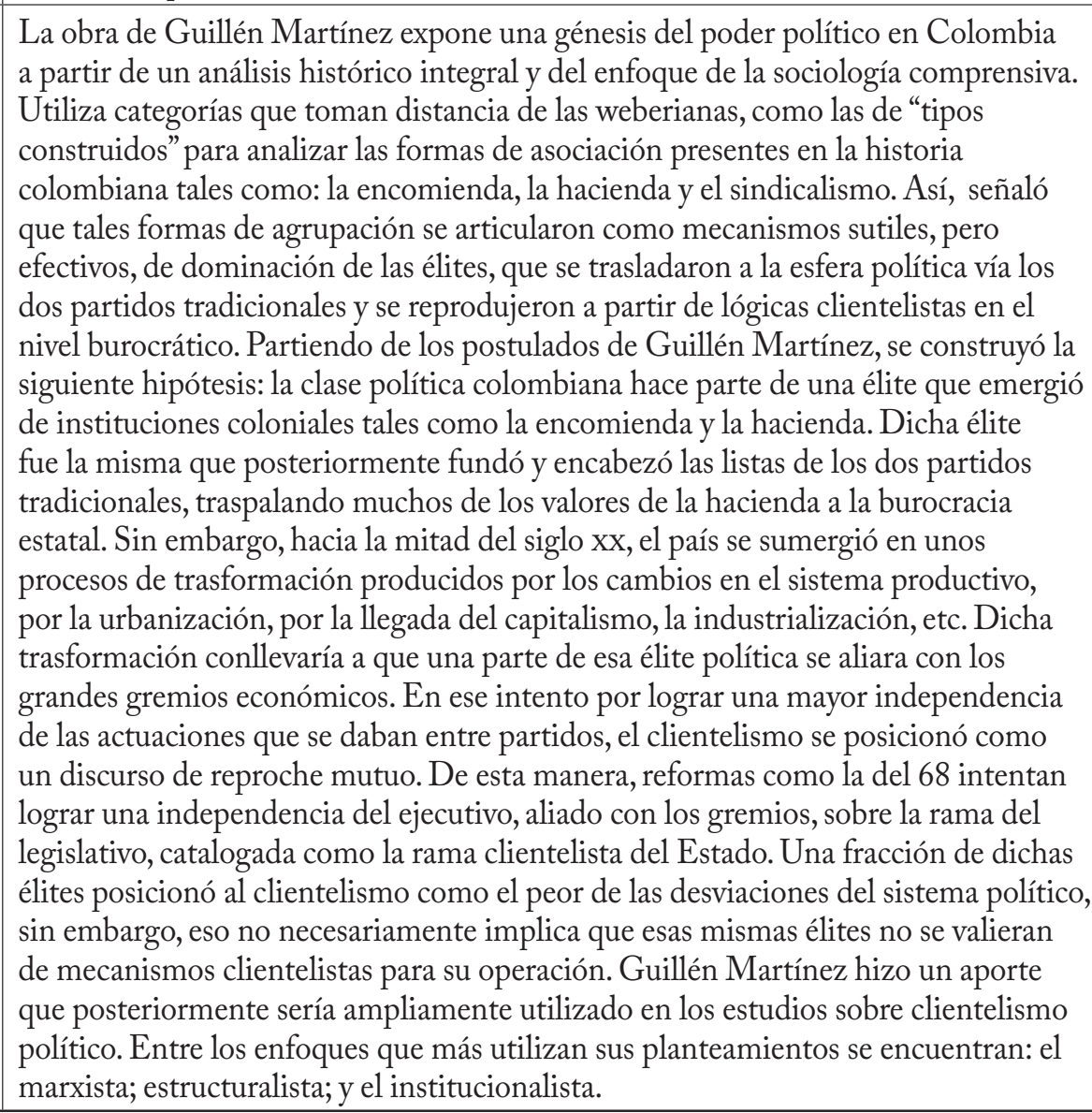 \\
\hline
\end{tabular}



$\mathrm{E}_{\text {ste libro fue compuesto en caracteres }}$ Adobe Caslon Pro 11,5 puntos, impreso sobre papel propal de 70 gramos y encuadernado con método hot melt, en diciembre de 2014, en Bogotá, D.C., Colombia. 